OPEN ACCESS

Edited by:

Lucia Recinella,

University of Studies G. d'Annunzio

Chieti and Pescara, Italy

Reviewed by:

Zhenzhou Jiang,

China Pharmaceutical University,

China

Stefania Tacconelli,

University of Studies G. d'Annunzio

Chieti and Pescara, Italy

${ }^{*}$ Correspondence:

Xiao Ma

tobymaxiao@163.com

Xiaomei Zhang

ZXM761@163.com

tThese authors have contributed equally to this work and share first

authorship

Specialty section:

This article was submitted to

Ethnopharmacology,

a section of the journal

Frontiers in Pharmacology

Received: 26 May 2021 Accepted: 04 November 2021

Published: 23 November 2021

Citation:

Zhao J, Zhang F, Xiao X, Wu Z, Hu Q Jiang $Y$, Zhang $W$, Wei S, Ma $X$ and

Zhang X (2021) Tripterygium hypoglaucum (Lévl.) Hutch and lts Main Bioactive Components: Recent Advances in Pharmacological Activity,

Pharmacokinetics and

Potential Toxicity.

Front. Pharmacol. 12:715359.

doi: 10.3389/fphar.2021.715359

\section{Tripterygium hypoglaucum (Lévl.) Hutch and Its Main Bioactive Components: Recent Advances in Pharmacological Activity, Pharmacokinetics and Potential Toxicity}

\author{
Junqi Zhao ${ }^{1 \dagger}$, Fangling Zhang ${ }^{1 \dagger}$, Xiaolin $\mathrm{Xiao}^{2}$, Zhao $\mathrm{Wu}^{1}$, Qichao $\mathrm{Hu}^{1}$, Yinxiao Jiang ${ }^{1}$, \\ Wenwen Zhang ${ }^{1}$, Shizhang Wei ${ }^{1}$, Xiao $\mathrm{Ma}^{1 *}$ and Xiaomei Zhang ${ }^{3 *}$ \\ ${ }^{1}$ State Key Laboratory of Southwestern Chinese Medicine Resources, School of Pharmacy, Chengdu University of Traditional \\ Chinese Medicine, Chengdu, China, ${ }^{2}$ Hospital of Chengdu University of Traditional Chinese Medicine, School of Clinical Medicine,

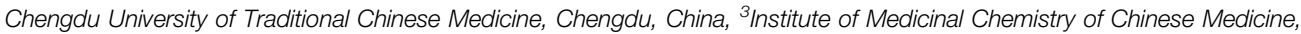 \\ Chongqing Academy of Chinese Materia Medica, Chongqing, China
}

Tripterygium hypoglaucum (Lévl.) Hutch $(\mathrm{THH})$ is believed to play an important role in health care and disease treatment according to traditional Chinese medicine. Moreover, it is also the representative of medicine with both significant efficacy and potential toxicity. This characteristic causes THH hard for embracing and fearing. In order to verify its prospect for clinic, a wide variety of studies were carried out in the most recent years. However, there has not been any review about $\mathrm{THH}$ yet. Therefore, this review summarized its characteristic of components, pharmacological effect, pharmacokinetics and toxicity to comprehensively shed light on the potential clinical application. More than 120 secondary metabolites including terpenoids, alkaloids, glycosides, sugars, organic acids, oleanolic acid, polysaccharides and other components were found in $\mathrm{THH}$ based on phytochemical research. All these components might be the pharmacological bases for immunosuppression, anti-inflammatory and anti-tumour effect. In addition, recent studies found that $\mathrm{THH}$ and its bioactive compounds also demonstrated remarkable effect on obesity, insulin resistance, fertility and infection of virus. The main mechanism seemed to be closely related to regulation the balance of immune, inflammation, apoptosis and so on in various disease. Furthermore, the study of pharmacokinetics revealed quick elimination of the main component triptolide. The feature of celastrol was also investigated by several models. Finally, the side effect of THH was thought to be the key for its limitation in clinical application. A series of reports indicated that multiple organs or systems including liver, kidney and genital system were involved in the toxicity. Its potential serious problem in liver was paid specific attention in recent years. In summary, considering the significant effect and potential toxicity of $\mathrm{THH}$ as well as its components, the combined medication to inhibit the toxicity, maintain effect might be a promising method for clinical conversion. Modern advanced technology such as structure optimization might be another way to 
reach the efficacy and safety. Thus, $\mathrm{THH}$ is still a crucial plant which remains for further investigation.

Keywords: Tripterygium hypoglaucum (Lévl.) Hutch., phytochemistry, pharmacology, pharmacokinetics, toxicity

\section{INTRODUCTION}

Effect and toxicity are two important aspects of drugs. Among the compounds obtained from plants or natural sources, agents with remarkable efficacy and potential toxicity have attracted much attention in recent years. It is well-known that some traditional Chinese medicine is highly toxic such as arsenic, Aconitum carmichaelii Debx. and Tripterygium wilfordii Hook F. (TwHF). Indeed, long-term consumption of arsenic can lead to arsenic accumulation in vital organs with diabetes, atherosclerosis, hypertension, ischemic heart disease, and hepatotoxicity (Khairul et al., 2017). However, arsenic trioxide $\left(\mathrm{As}_{2} \mathrm{O}_{3}\right)$ has recently shown significant efficacy in patients with acute promyelocytic leukemia (APL) and many other malignancies, such as adult T-cell leukemia/ lymphoma (ATL) and NPM1 mutant acute myeloid leukemia (AML) (Kchour et al., 2009; Mathews et al., 2011; El Hajj et al., 2015). In addition, fatal ventricular tachycardia and asystole may occur if aconite poisoning is severe (Chan, 2012). The processed Aconitum carmichaelii Debx. plays an important role as cardiotonic, analgesic and antiinflammatory in traditional medicine (Chan, 2011). Moreover, TwHF is frequently reported exhibiting multiple toxicity, including reproductive toxicity, renal cytotoxicity, and hepatotoxicity (Li X.-J. et al., 2014). However, due to its significant anti-inflammatory and immunosuppressive effects, TwHF preparations have been widely used for the treatment of autoimmune disorders and inflammatory diseases, such as rheumatoid arthritis (RA) (Luo et al., 2019; Xu et al., 2019). It is worth noting that multiple organ toxicity in TwHF can be resolved after dose adjustment (Zhang et al., 2021a). Therefore, the agents with both remarkable effect and potential toxicity should be paid specific focus.

Tripterygium hypoglaucum (Lévl.) Hutch. (THH), a plant distributed in southwest regions of China and along the south bank of the Yangtze River, has similar pharmacological effects with fewer side effects and lower toxicity than TwHF in the clinic (Li, 2006; Brinker et al., 2007; Ma et al., 2008) (Figure 1). Its main chemical components include alkaloids, diterpenoids and triterpenoids. Its root bark demonstrates excellent medicinal properties and has been widely used in folk medicine in China (Li, 2006). Numerous studies have found that terpenoids isolated from $\mathrm{THH}$ possess various pharmacological activities including anti-tumour, immunosuppressive and anti-inflammatory effects (Liu, 2011; Lü et al., 2015). Studies have shown that celastrol, a triterpenoid discovered from $\mathrm{THH}$, relieves insulin resistance, reduces body weight, and suppresses polycystic kidney disease (Booij et al., 2020). Despite significant efficacy, the clinical application of THH has a narrow therapeutic window due to severe toxicity, thereby limiting its widespread application (Dudics et al., 2018; Yuan et al., 2019a; Wang et al., 2019).
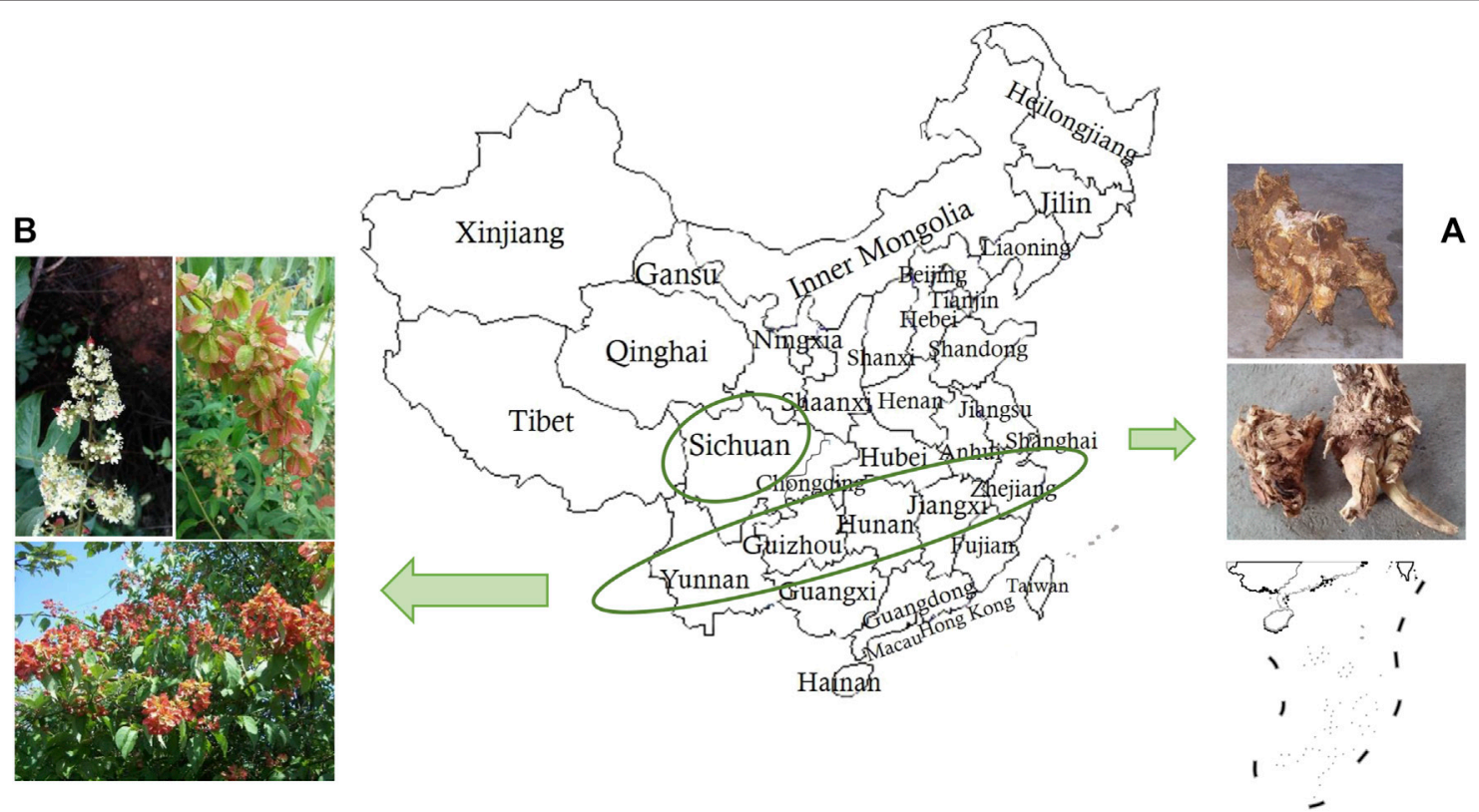

FIGURE 1 | Climatic and ecological adaptability distribution of $\mathrm{THH}$ in China. (A) Dried root bark of $\mathrm{THH}$, (B) Aerial view of $\mathrm{THH}$. 


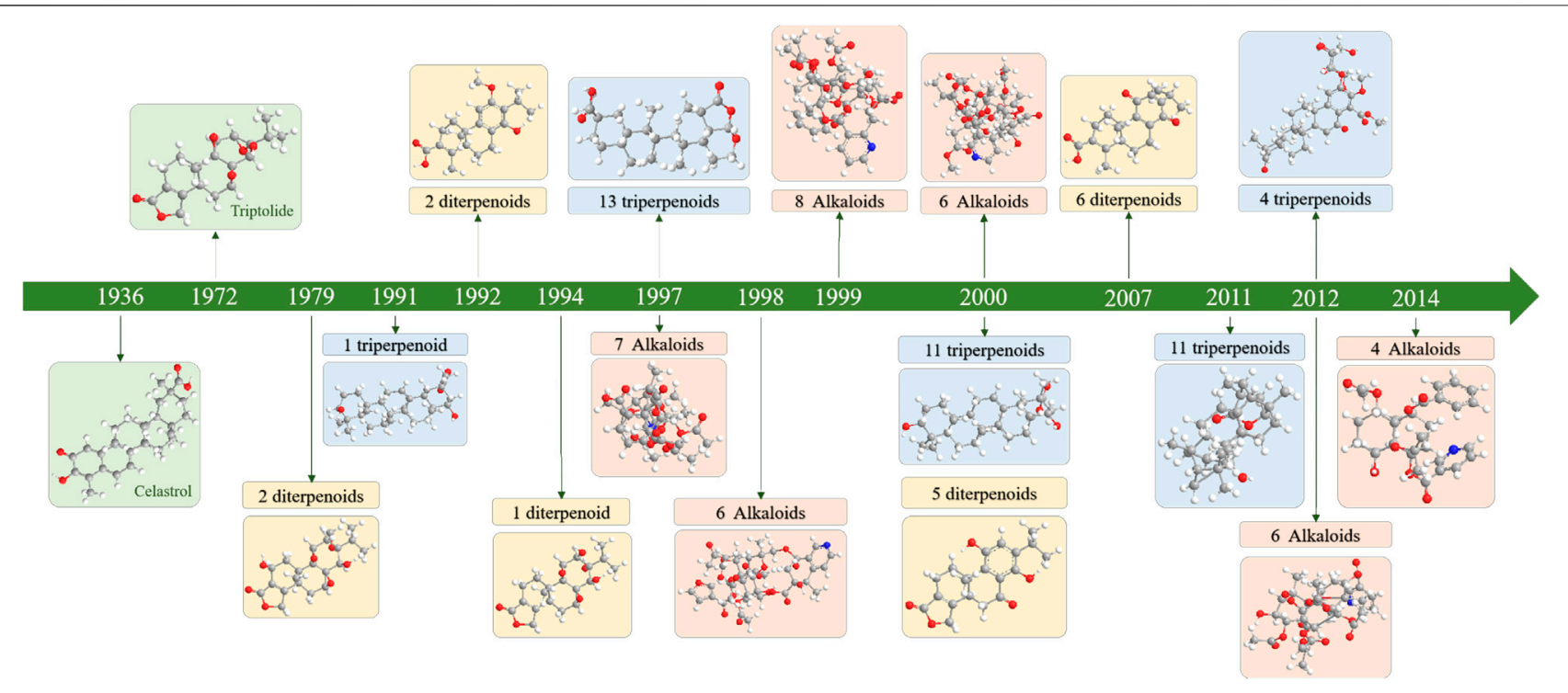

FIGURE 2 | Timeline of the isolation and identification of main chemical components from the genus Tripterygium.

Identification of the active chemical ingredients and pharmacological effects of $\mathrm{THH}$ is the primary goal of most THH studies, and this information is useful for the development of efficient and low-toxicity modern traditional Chinese medicines. The current research review on $\mathrm{THH}$ is limited, and sufficient attention has not been given to the relationship between compounds, pharmacological activities and toxicity. The chemical compositions and pharmacological mechanisms and potential toxicity of THH were studied to provide a scientific basis for the development of a safe medication with better clinical utility. To further clarify the chemical composition, mechanism of action, pharmacological effects and toxicity characteristics of $\mathrm{THH}$, we conducted the following review. We also summarized the pharmacokinetics study of $\mathrm{THH}$ in animals.

\section{METHODOLOGY}

Database searches using PubMed, China National Knowledge Internet (CNKI) and Wanfang database were conducted until December 2020. Tripterygium hypoglaucum (Lévl.) Hutch., Tripterygium, triptolide, celastrol and kunmingshanhaitang were searched as key words in the databases mentioned above. All of databases were retrieved twice. Experimental articles related to $\mathrm{THH}$ and its active components were included, and some irrelevant literature was excluded through reading abstracts or the full text. In almost all cases, the original articles were obtained and the relevant data was extracted.

\section{Phytochemical Constituents}

Since the 1960s, scholars have conducted in-depth research on TwHF through nearly half a century of chemical composition research on the genus Tripterygium (Figure 2). This plant genus contains more than 100 chemical components such as terpenoids (diterpenes, triterpenes, sesquiterpenes), alkaloids, glycosides, sugars, organic acids, euonymol, euonymus alkaloids, polysaccharides, $\beta$-sitosterol and other chemical components. Its characteristic active ingredients include diterpenoids such as triptolide, triptophenolide, triptriolide, triptoquinone $\mathrm{A}$, and triterpenoids, such as celastrol and wilforlide A (Xie et al., 2015) (Figure 3).

In the earliest study (1972) of the chemical composition of $\mathrm{THH}$, triptolide, triptolide diol, and triptolide ketone were isolated and identified from the ethanol-ethyl acetate extract of TwHF, a congeneric plant produced in China (Kupchan et al., 1972). In 1979, domestic studies in China first isolated trace amounts of two diterpene lactone chemical constituents, hypolide and tripterolide, from the root bark of TwHF. As a common chemical component of the three species of this genus, hypolides were isolated not only from $\mathrm{THH}$ but also from other species of the same genus, and it was hypothesized that hypolides might represent one of the precursors of biosynthesis in this genus $(\mathrm{Wu}$ and Sun, 1979).

A study reported that three rosin diterpenes, namely hypoglic acid, triptonoterpene methyl ether and triptonoterpenol could be separated from the ethyl acetate soluble portion of the root ethanol extract by silica gel column chromatography (Wang et al., 2012). An additional three ursolane triterpenes, namely hypoglaulide, triptotriterpenic acid $\mathrm{C}$ and regelin were obtained, and 3-acetoxy oleanolic acid was also obtained during the same separation process in 1992 (Zhang et al., 1992a). Ten crystals were obtained from the ethanol extract of the coarse powder of THH root: 3-oxofriedelan-29-oic acid methyl ester; $\beta$-sitosterol; 3-epik atonic acid methyl ester; $3 \beta, 22 \alpha$-dihydroxy- $\Delta 12$-oleanen-29-oic acid methyl ester; and $3 \beta, 22 \alpha$-dihydroxy- $\Delta 12$-ursen-30-oic acid methyl ester (Yi and Yang, 1993). In other studies, the chloroform extracts of $\mathrm{THH}$ roots were separated by column chromatography, and a total of 12 crystals were obtained. Of 


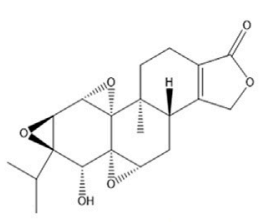

Triptolide

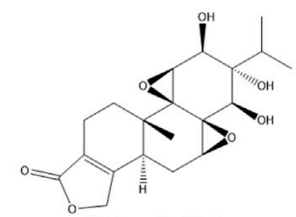

Triptriolide<smiles>CC1=C(O)C(=O)C=C2C1=CC=C1C2(C)CC[C@@]2(C)[C@@]1(C)CCC1(C)CCC(C)(C(=O)O)C[C@]12C</smiles>

Celastrol

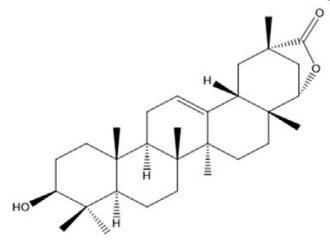

Wilforlide A

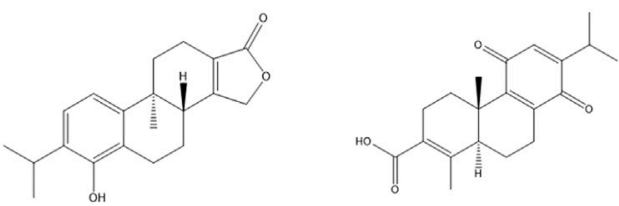

Triptophenolide

Triptoquinone A
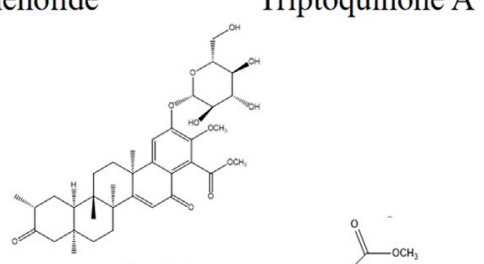

Hypoglaside A
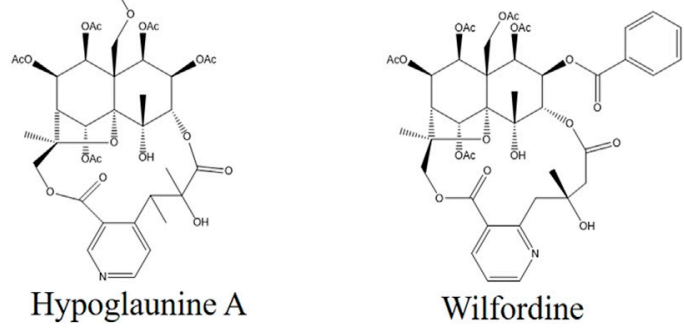

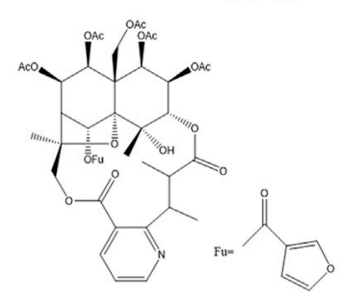

Hyponine A

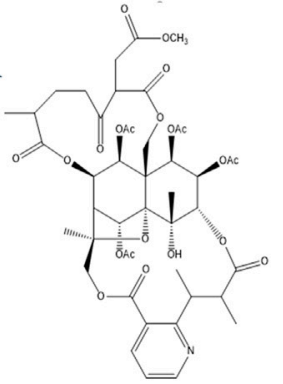

Triptonines A

FIGURE 3 | Chemical structures of the existing potential quality control markers in $\mathrm{THH}$.

these, 8 compounds were identified in 1992, including tripteroquinone, triptolide $\mathrm{A}$, triptolide $\mathrm{B}$, tripterygidine, triptolide, 1-epicatechin and $\beta$-sitosterol (Zhang and Zhang, 1992). They also reported that three diterpenoid compounds, namely, triptoditerpenic acid, tritoditerpenic acid $\mathrm{B}$ and hypodiolide $\mathrm{A}$, were obtained from the chloroform extracts of $\mathrm{THH}$ in the same year. In addition, other components, such as wilforgine and daucosterol, have been isolated from THH (Ding, 1991).

\section{Sesquiterpenoids}

Sesquiterpenes be isolated from $\mathrm{THH}$ mostly combine with pyridine to form alkaloids. At present, only two sesquiterpenoid monomeric compounds have been isolated from THH. In 2000, a sesquiterpene compound was isolated from the methanol extract of the root bark of THH. The molecular formula was $\mathrm{C}_{31} \mathrm{H}_{36} \mathrm{O}_{7}$, and the structural formula was $1 \beta$ benzoyl-8a-cinnamoyl-4a, 5a-dihydroxy dihydroagarofuran (Fujita et al., 2000). In 2014, a sesquiterpene compound was isolated from the $95 \%$ ethanol extract of the root bark of $\mathrm{THH}$. The molecular formula was $\mathrm{C}_{31} \mathrm{H}_{36} \mathrm{O}_{8}$ and the structural formula was: $\quad 1 \alpha$-acetoxy- $6 \beta, \quad 9 \beta$-dibenzoyloxy- $4 \beta$-hydroxydihydroagarofuran. These compounds exhibited weak cytotoxicity against $\mathrm{HeLa}$ cells with an $\mathrm{IC}_{50}$ value of $30.2 \mu \mathrm{M}$ (Liu Z.-Z. et al., 2014). Dihydro- $\beta$-agarofuran sesquiterpenes from $\mathrm{THH}$ are substrates of P-gp and potential modulators of MDR. These compounds exhibit no cytotoxicity in HepG2 and HepG2/ Adr cells. Moreover, these compounds restored the sensitivity of HepG2/Adr cells to Dox and increased the accumulation of intracellular Dox (Yang et al., 2019).

\section{Diterpenoids}

Diterpenoids are the most important components in $\mathrm{THH}$, and triptolide exhibits the most remarkable activity. Regarding the structural types of diterpenoids, epoxy-type diterpenoids, randolactone-type diterpenoids, fulfolterpenoid diterpenoids, kaurane-type diterpenoids and abietane-type diterpenoids are primarily observed in $\mathrm{THH}$.

One ranolactone-type diterpenoid, triptonolide, and two ranolterpene-type diterpenoids triptobenzene $\mathrm{A}$ and triptobenzene $\mathrm{J}$ were isolated from the methanol extract of THH (Duan et al., 1997). In addition, the following diterpenoids were isolated from the methanol extract of $\mathrm{THH}$ rhizomes in 2000: two ranolactone-type diterpenoids, triptobenzene $\mathrm{K}$ and triptophenolide; two fulfolterpenoid diterpenoids, triptobenzene $\mathrm{D}$ and triptobenzene $\mathrm{L}$; and one abietane-type diterpenoid, quinone 21 (Fujita et al., 2000). In 2007, three fulfolterpenoid diterpenoids (triptobenzene $\mathrm{H}$, triptonediol, and triptonoterpene) and three abietane-type diterpenoids (triptoquinone $\mathrm{A}$, triptoquinone $\mathrm{B}$, and triptoquinone $\mathrm{H}$ ) were isolated from $95 \%$ ethanol extracts of THH (Zhang et al., 2007). In 2011, a new fulfolterpenoid diterpenoid named triptonoterpene methyl ether was isolated from a 95\% ethanol extract of the root bark of THH (Liu et al., 2011). A randolactone-type diterpenoid, 11-O- $\beta-\mathrm{D}$ glucopyranosyl neotriptophenolide was isolated from a $95 \%$ ethanol extract of THH ( $\mathrm{Ti} \mathrm{X}, 2006)$. Four new diterpenoids, 2a, 16a-hydroxy-ent-kauran-19,20-olide, isopimara-8 (14), 15diene-11 $\beta, 19$-diol, isopimara-8 (14),15-diene-12 $\alpha, 19$-diol, and 3-oxo-14,15-dihydroxyabieta-8,11,13-trien-19-ol were isolated from $\mathrm{THH}$. Three new terpenoid compounds, epoxyionone A, 
TABLE 1 | Diterpenoids isolated from Tripterygium hypoglaucum.

\begin{tabular}{|c|c|c|c|c|}
\hline Serial number & Compound & Molecular formula & Plant part & References \\
\hline 1 & Hypolide & $\mathrm{C}_{20} \mathrm{H}_{24} \mathrm{O}_{3}$ & Root & Wu and Sun (1979) \\
\hline 2 & Triptonoterpenol & $\mathrm{C}_{21} \mathrm{H}_{30} \mathrm{O}_{4}$ & Root & Zhang et al. (1992b) \\
\hline 3 & Hypoglic acid & $\mathrm{C}_{20} \mathrm{H}_{26} \mathrm{O}_{4}$ & Root & Zhang et al. (1992b) \\
\hline 4 & Triptonoterpene methyl ether & $\mathrm{C}_{21} \mathrm{H}_{30} \mathrm{O}_{3}$ & Root & Zhang et al. (1992b) \\
\hline 5 & Hypodiolide A & $\mathrm{C}_{24} \mathrm{H}_{36} \mathrm{O}_{3}$ & Root & Zhang and Zhang (1992) \\
\hline 6 & Triptoditerpenic acid B & $\mathrm{C}_{21} \mathrm{H}_{28} \mathrm{O}_{3}$ & Root & Zhang and Zhang (1992) \\
\hline 7 & Triptonoditerpenic acid & $\mathrm{C}_{21} \mathrm{H}_{28} \mathrm{O}_{4}$ & Root & Zhang and Zhang (1992) \\
\hline 8 & Triptoquinone $\mathrm{H}$ & $\mathrm{C}_{20} \mathrm{H}_{26} \mathrm{O}_{3}$ & Root & Ding (1991) \\
\hline 9 & Triptobenzene L & $\mathrm{C}_{22} \mathrm{H}_{34} \mathrm{O}_{3}$ & Root & Ding (1991) \\
\hline 10 & Triptolide & $\mathrm{C}_{20} \mathrm{H}_{24} \mathrm{O}_{6}$ & Root & Duan et al. (1997) \\
\hline 11 & Triptonolide & $\mathrm{C}_{20} \mathrm{H}_{22} \mathrm{O}_{4}$ & Root & Duan et al. (1997) \\
\hline 12 & Triptobenzene A & $\mathrm{C}_{20} \mathrm{H}_{28} \mathrm{O}_{3}$ & Root & Duan et al. (1997) \\
\hline 13 & Triptobenzene J & $\mathrm{C}_{20} \mathrm{H}_{30} \mathrm{O}_{3}$ & Root & Duan et al. (1997) \\
\hline 14 & Triptobenzene K & $\mathrm{C}_{20} \mathrm{H}_{22} \mathrm{O}_{5}$ & Root & Duan et al. (1997) \\
\hline 15 & Neotriptophenolide & $\mathrm{C}_{21} \mathrm{H}_{26} \mathrm{O}_{4}$ & Root & Duan et al. (1997) \\
\hline 16 & $2 a, 16 a$-Hydroxy-ent-kauran-19,20-olide & $\mathrm{C}_{20} \mathrm{H}_{30} \mathrm{O}_{4}$ & Stem & Li et al. (2015b) \\
\hline 17 & Isopimara-8 (14), 15-diene-11 $\beta, 19$-diol & $\mathrm{C}_{20} \mathrm{H}_{32} \mathrm{O}_{2}$ & Stem & Li et al. (2015b) \\
\hline 18 & Isopimara-8 (14),15-diene-12a,19-diol & $\mathrm{C}_{20} \mathrm{H}_{32} \mathrm{O}_{2}$ & Stem & Li et al. (2015b) \\
\hline 19 & 3-Oxo-14,15-dihydroxyabieta-8,11,13-trien-19-ol & $\mathrm{C}_{20} \mathrm{H}_{28} \mathrm{O}_{4}$ & Stem & Li et al. (2015b) \\
\hline 20 & Triptobenzene W & $\mathrm{C}_{21} \mathrm{H}_{30} \mathrm{O}_{3}$ & Root & Zheng et al. (2020) \\
\hline 21 & Epoxyionone A & $\mathrm{C}_{19} \mathrm{H}_{28} \mathrm{O}_{6}$ & Root & Zheng et al. (2020) \\
\hline 22 & Loliolide A & $\mathrm{C}_{17} \mathrm{H}_{24} \mathrm{O}_{6}$ & Root & Zheng et al. (2020) \\
\hline 23 & Hypoglicin A & $\mathrm{C}_{20} \mathrm{H}_{30} \mathrm{O}_{4}$ & Stem & Chen et al. (2018b) \\
\hline 24 & Hypoglicin B & $\mathrm{C}_{20} \mathrm{H}_{24} \mathrm{O}_{3}$ & Stem & Chen et al. (2018b) \\
\hline 25 & Hypoglicin C & $\mathrm{C}_{19} \mathrm{H}_{20} \mathrm{O}_{3}$ & Stem & Chen et al. (2018b) \\
\hline 26 & Hypoglicin D & $\mathrm{C}_{20} \mathrm{H}_{26} \mathrm{O}_{5}$ & Stem & Chen et al. (2018b) \\
\hline 27 & Hypoglicin E & $\mathrm{C}_{20} \mathrm{H}_{28} \mathrm{O}_{2}$ & Stem & Chen et al. (2018b) \\
\hline 28 & Hypoglicin F & $\mathrm{C}_{20} \mathrm{H}_{28} \mathrm{O}_{2}$ & Stem & Chen et al. (2018b) \\
\hline 29 & Hypoglicin G & $\mathrm{C}_{20} \mathrm{H}_{28} \mathrm{O}_{2}$ & Stem & Chen et al. (2018b) \\
\hline 30 & Hypoglicin $\mathrm{H}$ & $\mathrm{C}_{20} \mathrm{H}_{26} \mathrm{O}_{3}$ & Stem & Chen et al. (2018b) \\
\hline 31 & Hypoglicin I & $\mathrm{C}_{20} \mathrm{H}_{26} \mathrm{O}_{3}$ & Stem & Chen et al. (2018b) \\
\hline 32 & Hypoglicin J & $\mathrm{C}_{20} \mathrm{H}_{26} \mathrm{O}_{3}$ & Stem & Chen et al. (2018b) \\
\hline 33 & Hypoglicin K & $\mathrm{C}_{20} \mathrm{H}_{22} \mathrm{O}_{6}$ & Stem & Chen et al. (2018b) \\
\hline 34 & Hypoglicin L & $\mathrm{C}_{20} \mathrm{H}_{22} \mathrm{O}_{6}$ & Stem & Chen et al. (2018b) \\
\hline 35 & Hypoglicin M & $\mathrm{C}_{19} \mathrm{H}_{20} \mathrm{O}_{4}$ & Stem & Chen et al. (2018b) \\
\hline 36 & 19-O- $\beta$-D-Glucopyranosyl-labda-8 (17),14-dien-13-ol & $\mathrm{C}_{26} \mathrm{H}_{44} \mathrm{O}_{7}$ & Aerial parts & Zhao et al. (2018) \\
\hline
\end{tabular}

triptobenzene $\mathrm{W}$ and loliolide A, were isolated from the $95 \%$ EtOH extract of the twigs of THH (Zheng et al., 2020). A new diterpenoid, 19-O- $\beta$-D-glucopyranosyl-labda-8 (17), 14-dien-13ol was isolated from the aerial parts of THH (Zhao et al., 2018) (Table 1).

The majority of diterpenoids exhibit strong immunosuppressive and anti-inflammatory activities. The inhibitory activity towards LPS-induced NO production of these terpenoids was evaluated in microglial BV-2 cells, and all of the compounds showed inhibitory effects (Zhao et al., 2014). Triptolide is a typical representative abietane terpenoid in $\mathrm{THH}$, that has been reported to have diverse pharmacological effects such as anti-inflammatory, antiproliferative, proapoptotic, immunosuppression, and tumour inhibition effects, and this compound exhibits great efficacy in the treatment of rheumatoid arthritis, asthma, and Shin disease (Shamon et al., 1997; Li J. et al., 2012; Chen S.-R. et al., 2018).

\section{Triterpenoids}

Triterpenoids are also one of the main components of THH. The triterpenoids found in $\mathrm{THH}$ are mainly pentacyclic triterpenoids, and three types are predominantly noted, including oleananetype, ursane-type and friedelane-type. Such pentacyclic triterpenoids are active ingredients in the treatment of autoimmune diseases.

One new triterpenoid named 6a-hydroxy triptoline, was isolated from the $95 \%$ ethanol extract of $\mathrm{THH}$ roots (Song et al., 2021). One friedelane-type triterpenoid (2,3-dihydroxy6-oxo-D:A-froedo-24 nor-1,3,5 (10), 7-oleanatetraen-29-oic acid) and other types of triterpenoids, including 23-noroxopristimerol and hypoglaside A, were isolated from the $95 \%$ ethanol extract of THH roots (Li X, 2006). Two oleanane-type triterpenoids, wilforlide $\mathrm{A}$ and 3-oxo-oleanoic acid were isolated from the chloroform emulsification layer of THH roots (Wang et al., 2011). One oleanane-type triterpenoid, triptotriterpenic acid A was isolated from $95 \%$ ethanol extract of the rhizomes of THH (Ding, 1991). The following triterpenoids were isolated from the methanol extract of THH rhizomes: four oleanane-type triterpenoids, including triptocallic acid D, triptocallic acid C, 3epikatonic acid, oleanoic acid 3-O-acetate; two friedelane-type triterpenoids, 29-hydroxyfriedelan-3-one and polpunonic acid; one ursane-type triterpenoid, $3 \beta$-acetoxy-urs-12-ene-28-oic acid; and other types of triterpenoids, such as triptohypol D, 
TABLE 2 | Triterpenoids isolated from Tripterygium hypoglaucum.

\begin{tabular}{|c|c|c|c|c|}
\hline Serial number & Compound & Molecular formula & Plant part & References \\
\hline 37 & Celastrol & $\mathrm{C}_{29} \mathrm{H}_{38} \mathrm{O}_{5}$ & Root & Duan et al. (1997) \\
\hline 38 & Wilforic acid $A$ & $\mathrm{C}_{29} \mathrm{H}_{42} \mathrm{O}_{4}$ & Root & Duan et al. (1997) \\
\hline 39 & Wilforol B & $\mathrm{C}_{29} \mathrm{H}_{42} \mathrm{O}_{4}$ & Root & Duan et al. (1997) \\
\hline 40 & Wilforic acid C & $\mathrm{C}_{30} \mathrm{H}_{48} \mathrm{O}_{4}$ & Root & Duan et al. (1997) \\
\hline 41 & Celastolide & $\mathrm{C}_{30} \mathrm{H}_{46} \mathrm{O}_{5}$ & Root & Duan et al. (1997) \\
\hline 42 & Hypodiol & $\mathrm{C}_{30} \mathrm{H}_{50} \mathrm{O}_{2}$ & Root & Duan et al. (1997) \\
\hline 43 & Salaspermic acid & $\mathrm{C}_{32} \mathrm{H}_{52} \mathrm{O}_{4}$ & Root & Duan et al. (1997) \\
\hline 44 & Cangoronine & $\mathrm{C}_{30} \mathrm{H}_{44} \mathrm{O}_{5}$ & Root & Duan et al. (1997) \\
\hline 45 & Popanonic acid & $\mathrm{C}_{30} \mathrm{H}_{48} \mathrm{O}_{3}$ & Root & Duan et al. (1997) \\
\hline 46 & Demthylzeylasteral & $\mathrm{C}_{30} \mathrm{H}_{38} \mathrm{O}_{6}$ & Root & Duan et al. (1997) \\
\hline 47 & Mesembryanthemoidigenic acid & $\mathrm{C}_{32} \mathrm{H}_{52} \mathrm{O}_{3}$ & Root & Duan et al. (1997) \\
\hline 48 & 3-Hydroxy-D: A friedoolean-3-en-2-on-29-oic-acid & $\mathrm{C}_{30} \mathrm{H}_{46} \mathrm{O}_{4}$ & Root & Duan et al. (1997) \\
\hline 49 & Triptohypol A & $\mathrm{C}_{30} \mathrm{H}_{40} \mathrm{O}_{6}$ & Root & Duan et al. (1997) \\
\hline 50 & Triptohypol B & $\mathrm{C}_{30} \mathrm{H}_{40} \mathrm{O}_{5}$ & Root & Duan et al. (1997) \\
\hline 51 & Triptohypol C & $\mathrm{C}_{29} \mathrm{H}_{39} \mathrm{O}_{4}$ & Root & Duan et al. (1997) \\
\hline 52 & Triptohypol D & $\mathrm{C}_{32} \mathrm{H}_{54} \mathrm{O}_{2}$ & Root & Fujita et al. (2000) \\
\hline 53 & Triptohypol E & $\mathrm{C}_{31} \mathrm{H}_{52} \mathrm{O}_{2}$ & Root & Fujita et al. (2000) \\
\hline 54 & Triptohypol F & $\mathrm{C}_{31} \mathrm{H}_{52} \mathrm{O}_{2}$ & Root & Fujita et al. (2000) \\
\hline 55 & Regelin & $\mathrm{C}_{31} \mathrm{H}_{48} \mathrm{O}_{4}$ & Root & Zhang et al. (1992a) \\
\hline 56 & hypoglaulide & $\mathrm{C}_{30} \mathrm{H}_{44} \mathrm{O}_{3}$ & Root & Zhang et al., (1992a) \\
\hline 57 & 3-Oxofriedelan-29-oic acid methyl ester & $\mathrm{C}_{32} \mathrm{H}_{52} \mathrm{O}_{3}$ & Root & Yi and Yang (1993) \\
\hline 58 & $3 \beta, 22 \alpha$-Dihydroxy- $\Delta^{12}$-ursen-30-oic acid methyl ester & $\mathrm{C}_{30} \mathrm{H}_{48} \mathrm{O}_{4}$ & Root & Yi and Yang (1993) \\
\hline 59 & $3 \beta, 22 \alpha$-Dihydroxy- $\Delta^{12}$-oleanen-29-oic acid methyl ester & $\mathrm{C}_{30} \mathrm{H}_{50} \mathrm{O}$ & Root & Yi and Yang (1993) \\
\hline 60 & Friedelin & $\mathrm{C}_{30} \mathrm{H}_{50} \mathrm{O}$ & Root bark & Liu et al. (2011) \\
\hline 61 & 3-Oxo-olean-9 (11),12-diene & $\mathrm{C}_{30} \mathrm{H}_{46} \mathrm{O}$ & Root bark & Liu et al. (2011) \\
\hline 62 & Canophyllal & $\mathrm{C}_{30} \mathrm{H}_{48} \mathrm{O}_{2}$ & Root bark & Liu et al. (2011) \\
\hline 63 & 6a-Hydroxy triptocslline & $\mathrm{C}_{28} \mathrm{H}_{42} \mathrm{O}_{5}$ & Root & Song et al. (2021) \\
\hline
\end{tabular}

triptohypol E, triptohypol F, and hypodiol (Fujita et al., 2000). The following triterpenoids were isolated from the methanol extract of $\mathrm{THH}$ roots: one oleanane-type triterpenoid, mesembryanthemoidigenic acid; ten friedelane-type triterpenoids, celastolide, triptoethylol A, wilforic acid A, triptohypol B, triptohypol C, wilforol A, wilforol B, demethylzeylasteral, wilforic acid $\mathrm{C}$, and cangoronine; and other types of triterpenoids, including salaspermic acid and 23-nor-6-oxo-demethyl pristimerol (Duan et al., 1997). Three oleanane-type triterpenoids, including 3 -acetoxy oleanolic acid, glut-5-en-3 $\beta, 28$-diol, and 3-oxo-olean- $\Delta 9(11), 12$-diene and two friedelane-type triterpenoids, canophyllal and friedelin were isolated from $95 \%$ ethanol extracts of the root bark of $\mathrm{THH}$ (Liu et al., 2011) (Table 2). Celastrol, the first triterpenoid ingredient isolated from the genus Tripterygium, is classified as a friedelane-type triterpenoid. Its toxicity is much lower than that of triptolide. Celastrol has significant anticancer effects and relieves insulin resistance. Thus, celastrol has attracted considerable attention in recent years (Petronelli et al., 2009; Yang et al., 2014).

\section{Alkaloids}

Alkaloids are one of the strongest bioactive ingredients found in the $\mathrm{THH}$ extract. The alkaloids obtained from $\mathrm{THH}$ exhibit pyridine alkaloid structures formed by condensation of dihydroagarofuran-type sesquiterpenes with different pyridinic acids. Studies have shown that alkaloids found in THH from traditional Chinese medicine exhibit antitumour activity in animals.
In 1997, seven alkaloids were isolated from the methanol extract of $\mathrm{THH}$ roots: euonine, hyponine $\mathrm{A}$, hyponine $\mathrm{B}$, hyponine $\mathrm{C}$, cangorinine $\mathrm{E}-\mathrm{I}$, regelidine, and 3pyridinecarboxylic acid (Duan et al., 1997). Then, six alkaloids were isolated from the methanol extract of $\mathrm{THH}$ roots in 1998: hypoglaunine A, hypoglaunine $\mathrm{B}$, hypoglaunine $\mathrm{C}$, hypoglaunine $\mathrm{D}$, euonymine, and wilforine (Duan and Takaishi, 1998). Two new alkaloids, wilfordine and wilformine were isolated from the ethanol extract of $\mathrm{THH}$ roots in 1999 (Li et al., 1999). Moreover, hyponines D, hyponines E, hyponines $\mathrm{F}$, neoeunoymine and forestine were isolated from the methanol extract of THH roots (Duan and Takaishi, 1999). In 2000, six alkaloids were isolated from the methanol extract of $\mathrm{THH}$ roots: triptonines $\mathrm{A}$, triptonines $\mathrm{B}$, wilfordinines $\mathrm{A}$, wilfordinines $\mathrm{B}$, wilfordinines $\mathrm{C}$ and peritassine $\mathrm{A}$ (Duan et al., 2000). In 2012, two sesquiterpene pyridine alkaloids, hypoglaunine $\mathrm{E}$ and hypoglaunine $\mathrm{F}$ were isolated from $95 \%$ ethanol extracts of THH roots (Li X, 2006). Then, four alkaloids, 2-O-deacetyleuonine, wilfortrine, triptolide (wilforgine) and tripfordine C were isolated from a $95 \%$ ethanol extract of the root bark of THH (Xie et al., 2012). In 2014, four new alkaloid compounds were isolated from the methanol extract of the rhizome of THH: $9 \alpha$-cinnamoyloxy-1 $\beta$-furoyloxy-4-hydroxy$6 \alpha$-nicotinoyloxy- $\beta$-dihydroagarofuran, $1 \beta, 9 \alpha$-dibenzoyloxy-4hydroxy-6a-nicotinoyloxy- $\beta$-dihydroagarofuran, $1 \beta$-benzoyloxy- $9 \alpha$ cinnamoyloxy-4-hydroxy-6a-nicotinoyloxy- $\beta$-dihydroagarofuran and $1 \beta$-acetoxy-9a-benzoyloxy-4-hydroxy- $6 \alpha$-nicotinoyloxy$\beta$-dihydroagarofuran (Chen X.-L. et al., 2018) (Table 3). The alkaloid fraction in $\mathrm{THH}$ is characterized by high 
TABLE 3 | Alkaloids isolated from Tripterygium hypoglaucum.

\begin{tabular}{|c|c|c|c|c|}
\hline Serial number & Compound & Molecular formula & Plant part & References \\
\hline 64 & Hypoglaunine A & $\mathrm{C}_{41} \mathrm{H}_{47} \mathrm{O}_{20} \mathrm{~N}$ & Root & Duan and Takaishi (1998) \\
\hline 65 & Hypoglaunine B & $\mathrm{C}_{41} \mathrm{H}_{47} \mathrm{O}_{20} \mathrm{~N}$ & Root & Duan and Takaishi (1998) \\
\hline 66 & Hypoglaunine $\mathrm{C}$ & $\mathrm{C}_{43} \mathrm{H}_{49} \mathrm{O}_{19} \mathrm{~N}$ & Root & Duan and Takaishi (1998) \\
\hline 67 & Hypoglaunine D & $\mathrm{C}_{41} \mathrm{H}_{47} \mathrm{O}_{19} \mathrm{~N}$ & Root & Duan and Takaishi (1998) \\
\hline 68 & Wilforine & $\mathrm{C}_{43} \mathrm{H}_{49} \mathrm{O}_{18} \mathrm{~N}$ & Root & Duan and Takaishi (1998) \\
\hline 69 & Wilforgine & $\mathrm{C}_{41} \mathrm{H}_{47} \mathrm{O}_{19} \mathrm{~N}$ & Root & Duan and Takaishi (1998) \\
\hline 70 & Wilfordine & $\mathrm{C}_{43} \mathrm{H}_{49} \mathrm{O}_{19} \mathrm{~N}$ & Root & Duan and Takaishi (1998) \\
\hline 71 & Wilfortrine & $\mathrm{C}_{41} \mathrm{H}_{47} \mathrm{O}_{20} \mathrm{~N}$ & Root & Duan and Takaishi (1998) \\
\hline 72 & Euonymine & $\mathrm{C}_{38} \mathrm{H}_{47} \mathrm{O}_{18} \mathrm{~N}$ & Root & Duan and Takaishi (1998) \\
\hline 73 & Wilformine & $\mathrm{C}_{41} \mathrm{H}_{48} \mathrm{O}_{18} \mathrm{~N}_{2}$ & Root & Duan and Takaishi (1998) \\
\hline 74 & Wilfornine & $\mathrm{C}_{41} \mathrm{H}_{47} \mathrm{O}_{19} \mathrm{~N}$ & Root & Duan and Takaishi (1998) \\
\hline 75 & Hyponine A & $\mathrm{C}_{41} \mathrm{H}_{47} \mathrm{O}_{19} \mathrm{~N}$ & Root & Duan et al. (1997) \\
\hline 76 & Hyponine B & $\mathrm{C}_{41} \mathrm{H}_{47} \mathrm{O}_{19} \mathrm{~N}$ & Root & Duan et al. (1997) \\
\hline 77 & Hyponine C & $\mathrm{C}_{43} \mathrm{H}_{49} \mathrm{O}_{18} \mathrm{~N}$ & Root & Duan et al. (1997) \\
\hline 78 & Cangorinine E-I & $\mathrm{C}_{43} \mathrm{H}_{49} \mathrm{O}_{18} \mathrm{~N}$ & Root & Duan et al. (1997) \\
\hline 79 & Evonine & $\mathrm{C}_{36} \mathrm{H}_{43} \mathrm{O}_{17} \mathrm{~N}$ & Root & Duan et al. (1997) \\
\hline 80 & 3-Pyridinecarboxylic acid & $\mathrm{C}_{29} \mathrm{H}_{34} \mathrm{O}_{7} \mathrm{~N}$ & Root & Duan et al. (1997) \\
\hline 81 & Hyponine D & $\mathrm{C}_{47} \mathrm{H}_{50} \mathrm{O}_{18} \mathrm{~N}_{2}$ & Root & Duan and Takaishi, (1999) \\
\hline 82 & Hyponine E & $\mathrm{C}_{45} \mathrm{H}_{48} \mathrm{O}_{19} \mathrm{~N}_{2}$ & Root & Duan and Takaishi (1999) \\
\hline 83 & Hyponine F & $\mathrm{C}_{41} \mathrm{H}_{47} \mathrm{O}_{19} \mathrm{~N}$ & Root & Duan and Takaishi (1999) \\
\hline 84 & Neoeunoymine & $\mathrm{C}_{36} \mathrm{H}_{45} \mathrm{O}_{17} \mathrm{~N}$ & Root & Duan and Takaishi (1999) \\
\hline 85 & Forrestine & $\mathrm{C}_{43} \mathrm{H}_{49} \mathrm{O}_{18} \mathrm{~N}$ & Root & Duan and Takaishi (1999) \\
\hline 86 & Peritassine A & $\mathrm{C}_{39} \mathrm{H}_{49} \mathrm{O}_{18} \mathrm{~N}$ & Root & Duan et al. (2000) \\
\hline 87 & Regelidine & $\mathrm{C}_{35} \mathrm{H}_{37} \mathrm{O}_{8} \mathrm{~N}$ & Root & Duan et al. (2000) \\
\hline 88 & Triptonine A & $\mathrm{C}_{45} \mathrm{H}_{55} \mathrm{O}_{21} \mathrm{~N}$ & Root & Duan et al. (2000) \\
\hline 89 & Triptonine B & $\mathrm{C}_{45} \mathrm{H}_{55} \mathrm{O}_{22} \mathrm{~N}$ & Root & Duan et al. (2000) \\
\hline 90 & Wilfordinine A & $\mathrm{C}_{36} \mathrm{H}_{55} \mathrm{O}_{12} \mathrm{~N}$ & Root & Duan et al. (2000) \\
\hline 91 & Wilfordinine B & $\mathrm{C}_{38} \mathrm{H}_{60} \mathrm{O}_{13} \mathrm{~N}$ & Root & Duan et al. (2000) \\
\hline 92 & Wilfordinine C & $\mathrm{C}_{43} \mathrm{H}_{60} \mathrm{O}_{14} \mathrm{~N}$ & Root & Duan et al. (2000) \\
\hline 93 & 2-O-Deacetyleuonine & $\mathrm{C}_{36} \mathrm{H}_{45} \mathrm{O}_{17} \mathrm{~N}$ & Root bark & Xie et al. (2012) \\
\hline 94 & Tripfordine C & $\mathrm{C}_{36} \mathrm{H}_{45} \mathrm{O}_{17} \mathrm{~N}$ & Root bark & Xie et al. (2012) \\
\hline 95 & 1-a-Benzoyloxy- $6 \beta$-nicotinoyloxy- $9 \beta$-acetoxy- $4 \beta$-hydroxy-dihydro- $\beta$-agarofuran & $\mathrm{C}_{30} \mathrm{H}_{35} \mathrm{O}_{8} \mathrm{~N}$ & Root & Duan et al. (2000) \\
\hline
\end{tabular}

activity and low toxicity; thus, these compounds exhibit potential value in new drug development research.

\section{Flavonoids}

In 1998, two flavonoids were isolated from industrial alcohol extracts of THH stems: (+) -catechin and L-epicatechin (Zhang and Zhang, 1998). In 2012, two flavonoids were isolated from a 95\% ethanol extract of the root bark of THH: $4^{\prime}-\mathrm{O}-(-)$ methylepigallocatechin and (2R, 3R)-3,5,7,3',5'-pentahydroxyflavan (Xie et al., 2012).

\section{Lignans}

Three new lignans, 9'-O-benzoyl-lariciresinol, 9'-O-benzoyl-5' methoxylariciresinol, and $9^{\prime}$-O-cinnamoyl-lariciresinol, were isolated from the $95 \% \mathrm{EtOH}$ extract of the twigs of $\mathrm{THH}$. Moreover, only 9'-O-benzoyl-lariciresinol showed weak cytotoxicity against HepG2/Adr cells, with an IC50 value of $30.1 \mu \mathrm{M}$ in vitro (Liu et al., 2011). Recently, syringaresinol, a common bisepoxylignan, was isolated from the 95\% $\mathrm{EtOH}$ extract of THH (Song et al., 2021).

\section{Other Compounds}

In addition to diterpenes, triterpenes and alkaloids, other compounds, such as steroids, fatty acids, tannins and glycosides, have been identified in THH. Although terpenoids are the main pharmacodynamic components of $\mathrm{THH}$, other components also play synergistic roles.

In 1991, two steroidal compounds, $\beta$-sitosterol and daucosterol, and one other compound, fumaric acid, were isolated from the $95 \%$ ethanol extract of the rhizome of $\mathrm{THH}$ (Ding L, 1991). Two steroidal compounds, ergosta-4,6,8 (14), 22tetraen-3-one and stigmast-4-en-3-one and three other compounds, $p$-hydroxyl benzoic acid, 3,4-dihydroxy-benzoic acid, and 3-meth-oxy-4-hydroxy-benzoic acid were isolated from the ether extract of THH stems (Zhang and Zhang, 1998). In 2011, three fatty acid compounds, palmitic acid, stearic acid and tricosanoic acid were isolated from the $95 \%$ ethanol extract of the root bark of THH (Liu et al., 2011). Two tannins were isolated from industrial alcohol extracts of $\mathrm{THH}$ stems: procyanidin B-3 and procyanidin B-4 (Zhang and Zhang, 1998). In 2011, a tannin compound, procyanidin B-2, was isolated from the chloroform emulsified layer of $\mathrm{THH}$ roots (Petronelli et al., 2009). Two glycosides, 3,4-dimethoxyphenyl- $\beta$-Dglucopyranoside and 3,4,5-trimethoxyphenyl- $\beta$-Dglucopyranoside were isolated from the $95 \%$ ethanol extract of the root bark of THH (Xie et al., 2012).

\section{Pharmacological Activity}

$\mathrm{THH}$ is a traditional medicine that exhibits various pharmacological activities, including anti-inflammation, 


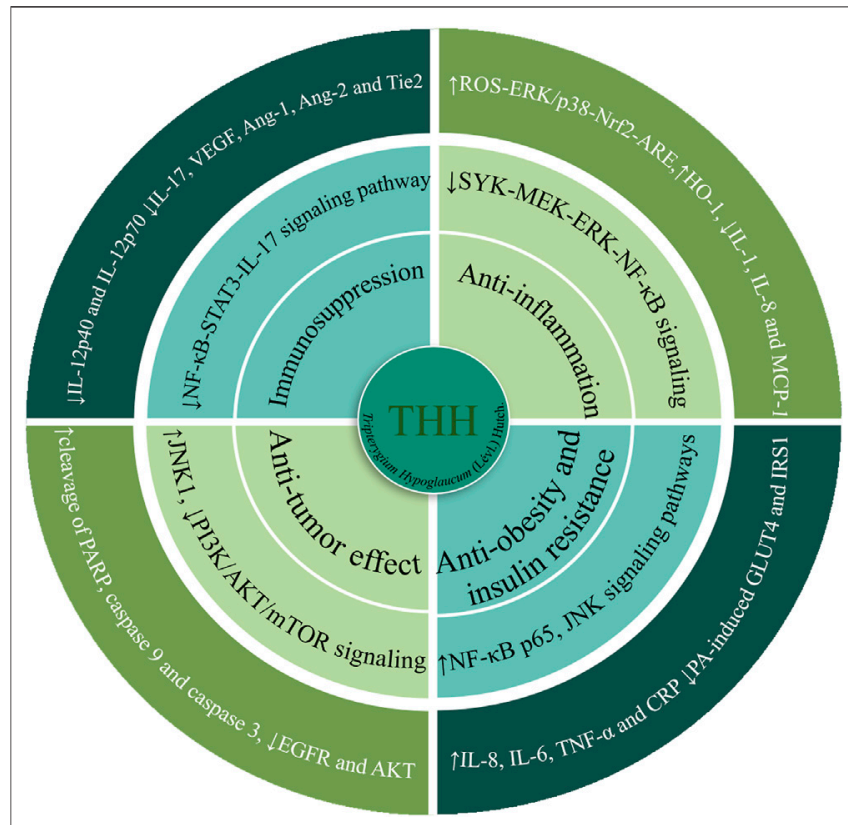

FIGURE 4 | The main signalling pathways and molecular targets of the pharmacologically active components in $\mathrm{THH}$.

immunosuppression, antitumour, obesity and insulin resistance, antifertility, and antiviral effects. These pharmacological effects are mainly related to the alkaloids and terpenoids of THH. These components are expected to exhibit therapeutic significance in various human immunological diseases, such as rheumatoid arthritis, systemic lupus erythematosus, acute infectious hepatitis, chronic nephritis, leukemia, neurodermatitis, and chronic urticaria (Guo et al., 2018; Tang et al., 2020). Here, we summarized several classical pharmacological activities of $\mathrm{THH}$ (Figure 4, Tables 4 and 5).

\section{Anti-Inflammatory Effects}

Corticosteroids are widely used as anti-inflammatory drugs, but some serious side effects often occur after long-term use. THH has been shown to be effective in a variety of inflammatory diseases. Under the condition of reasonable control of THH toxicity, $\mathrm{THH}$ is expected to play a huge potential as an alternative drug. The therapeutic mechanisms of $\mathrm{THH}$ include the inhibition of inflammation and capillary permeability as well as the reduction of infiltrates. Moreover, Hypoglicins B-G and J-M, which are isolated from the stem of $\mathrm{THH}$, inhibited $\mathrm{NO}$ production with $\mathrm{IC}_{50}$ values ranging from 0.72 to $36.91 \mu \mathrm{M}$. Moreover, hypoglicin $\mathrm{D}$ and hypoglicin L significantly inhibit the mRNA expression of iNOS at doses of 12.5 and $3.13 \mu \mathrm{M}$, respectively (Chen X.-L. et al., 2018). Importantly, the compounds found in $\mathrm{THH}$ do not act through the pituitary-adrenal cortex system, so there will be no "rebound" phenomenon after stopping the drug, and even long-term use will not damage the immune system (Zhong et al., 2011), but the toxic accumulation of long-term use must be considered carefully.

The mechanism by which triptolide attenuates the inflammatory pathology of Crohn's disease (CD) involves increasing IL-10 levels and Foxp3+ Tregs in the mucosa and decreasing TNF- $\alpha$ levels in the mucosa (Li G. et al., 2014). The pathogenesis of $\mathrm{CD}$ is mainly mediated by the TLR/NF- $\kappa \mathrm{B}$ signalling pathway. Triptolide upregulates TLR2 and TLR4 in a CD model in IL-10-null (IL-10 -/-) mice by inhibiting TLR/ NF- $\kappa \mathrm{B}$ signalling pathways in vivo. TLR activation also promotes angiogenesis mediated by exogenous and endogenous ligands in different inflammatory settings (Harmey et al., 2002; Oda and Kitano, 2006; Yu et al., 2010). A key regulator of the signal transduction cascade activated by NF- $\mathrm{KB}$ and activator protein-1 is TAK1. However, for TAK1 to be fully activated, it must be induced by a protein activator, TAK1 binding protein (TAB1). Triptolide interferes with the formation of the TAK1TAB1 complex and thus inhibits the activity of TAK1 kinase. The interaction region between triptolide and TAB1 involves the amino acid residues between TAB1373 and 502. Triptolide inhibits MAPK pathway activation in macrophages upon binding to TAB1 ( $\mathrm{Lu}$ et al., 2014). In addition, triptolide inhibited the activation of microglia and the secretion of inflammatory factors in BV2 cells by upregulating miR96 (Huang et al., 2019). Moreover, the $\gamma$-butyrolactone and C-14 $\beta$-hydroxyl portions of the triptolide molecules are important components responsible for the compound's anti-inflammatory characteristics and cytotoxicity (Wong et al., 2008). Triptolide suppresses the production of IL-6, IL- 8 , TNF- $\alpha$, and IL- $1 \beta$ in human bronchial epithelial cells, and inhibits staphylococcal exotoxin-stimulated T-cell proliferation. Triptolide induces the expression of monocyte chemotactic protein (MCP)-1, IFN-g, TNF, IL-6, IL-1 $\beta$, macrophage inflammatory protein (MIP)- $1 \beta$ and MIP-1 $\alpha$ in peripheral blood mononuclear cells (PBMCs) (Krakauer et al., 2005).

Angiogenesis is a fundamental event in inflammation. Infection leads to inflammation and growth factors released by leukocytes promote angiogenesis. Many chronic inflammatory diseases, such as retinopathy, rheumatoid arthritis, Crohn's disease, atherosclerosis, diabetes and cancer are closely associated with angiogenesis (McDonald, 2001; RodríguezMartínez et al., 2006; Costa et al., 2007). Celastrol achieves its effect mainly by regulating various inflammatory mediators ( $\mathrm{Li}$ et al., 2008; Li G. et al., 2013), inhibiting the production of proinflammatory cytokines (IL-6, IL-2, IFN- $\gamma$, TNF, IL- $1 \beta$, IL8 , etc.) and proinflammatory enzymes (COX-1, prostaglandin $\mathrm{E} 2, \mathrm{NOS}, \mathrm{COX}-2$ and iNOS, etc.) through inhibition of NF- $\kappa \mathrm{B}$ (Lee et al., 2006; Jung et al., 2007; Kim et al., 2009; Seo et al., 2010, 2011; Cascão et al., 2012; Joshi et al., 2016). In addition, celastrol interferes with the migration, proliferation, and activation of inflammatory cells (Yu et al., 2015). Celastrol suppresses the LPS-induced I $\mathrm{KB}$ kinase $(\mathrm{IKK}) / \mathrm{NF}-\kappa \mathrm{B}$ pathway, significantly downregulates TLR4 expression and inhibits VEGF secretion in LP-1 cells. These results suggest that celastrol inhibits LPSinduced angiogenesis by inhibiting TLR4-triggered NF- $\kappa B$ activation (Zhang R. et al., 2019).

\section{Immunosuppression}

THH was used to treat various autoimmune diseases based on its action against metabolic pathways, and three metabolites, urocanate, L-glutamate and alanine played very important roles (Guo et al., 2018). The key molecular mechanism of 
$\mathrm{THH}$ against RA is related to inhibition of the inflammatory response through inactivation of the TNF and NF- $\kappa \mathrm{B}$ signalling pathways (Jiang et al., 2020b). THH reduces the expression of related inflammatory cytokines in joint tissue and serum, and the mechanism of THH in the treatment of collagen II-induced arthritis (CIA) mice involves inhibition of the NF- $\kappa$ B-STAT3IL-17 pathway (Zhou et al., 2020). The formation and function of osteoclasts in CIA mice are directly inhibited by celastrol. Celastrol significantly reduced joint bone damage, and inhibited arthritis, and this activity is associated with the expression of the osteoclast marker serum tartrate-resistant acid phosphatase (TRAP) 5b and osteoclastic genes (Ctr, Mmp-9, Ctsk and Trap) and transcription factors (NFATc1 c-Jun and c-Fos). Moreover, celastrol suppressed bone resorption activity and the formation of TRAP + multinucleate cells in a dose-dependent manner (Gan et al., 2015).

Triptolide and celastrol are the most important active ingredients of $\mathrm{THH}$ against RA, and their molecular mechanisms involve many targets, such as inhibition of inflammation, inhibition of angiogenesis, immunosuppression, protection of cartilage, and induction of apoptosis (Kong et al., 2013; Fan et al., 2016, 2018; Wang S. et al., 2018). The expression of chemokines and inflammatory cytokines in RA synovioblasts is inhibited by celastrol through modulation of the OPG/RANKL axis, thereby inhibiting RA inflammation and bone erosion (Feng et al., 2013). Celastrol also decreases the expression of NF- $\kappa B$, nitrite levels, and TLR2 expression and $\mathrm{CD}^{+}$Tlymphocyte counts as assessed by immunohistochemistry; and the cytokine phenotype changes significantly from Th1 to Th2, with increased IL-10 and decreased TNF- $a$ levels. (Abdin and Hasby, 2014). In addition, the binding of LPS to the TLR4/MD2 complex and TLR4 activation were also inhibited by celastrol in a thioldependent manner (Lee et al., 2015). Celastrol suppresses the expression of phosph-stat3, c-Myc, Glut1, mTOR, HK2, HIF-1a and Akt in Th17 cells; upregulates the expression of phosph-stat5 in iTreg cells, and upregulates the expression of CPT1A and AMPKa in iTreg cells to promote fatty acid-oxidation (Zhang et al., 2018).

Triptolide inhibits the production of proMMP-1 and -3 induced by IL-1 $\alpha$ in human synovial fibroblasts and reduces the messenger RNA levels of IL-1 $\alpha$. In contrast, the IL-1alphainduced gene expression and production of TIMP-1 and-2 were further augmented by triptolide in synovial cells. Triptolide also inhibited the IL-1alpha-induced production of PGE2 by selectively suppressing the gene expression and production of COX-2, but not COX-1 (Lin et al., 2001) (Hu et al., 2004). Triptolide inhibits the production of IL-2, IL-4, and IFN- $\gamma$ and the activation of $\mathrm{CD}^{+}$and $\mathrm{CD}^{+} \mathrm{T}$ cells in peripheral blood in RA patients, thus exerting an immunosuppressive effect (Ren et al., 2010) (Nong et al., 2019). Professional antigen presenting cells (APCs), such as dendritic cells (DCs), are another target for the immunosuppressive activity of triptolide (Chen et al., 2005). DCs are induced by high concentrations $(20 \mathrm{ng} / \mathrm{ml})$ of triptolide via caspase 3 activation and sequential p38 MAP kinase phosphorylation (Liu et al., 2004; Liu et al., 2006). Triptolide also inhibits T cells and DC-mediated chemoattraction of neutrophils by reducing NF- $\kappa$ B activation and STAT3 phosphorylation (Zhu et al., 2005). Triptolide prevents the differentiation of immature monocyte-derived DCs (MoDCs), mainly by reducing the ability of MoDCs to stimulate lymphocyte proliferation in allogeneic mixed lymphocyte reactions (MLRs) and downregulating CD86, CD40, CD1a, CD80, and HLA-DR expression. Triptolide reduces IFN- $\gamma$-induced expression of CD80 and CD86 in DCs and THP-1 cells (Liu et al., 2005). Recently, it was found that triptolide inhibited IL-12/IL-23 expression in APCs via CCAAT/ enhancer-binding protein a (Liu et al., 2008).

\section{Antitumour Effects}

The alkaloid fraction of $\mathrm{THH}$ induced apoptosis at lower concentrations and significantly inhibited tumour growth in vitro and in vivo. In addition, the apoptotic effect of total alkaloids in tumour cells is potentially mediated through both the extrinsic death receptor pathway and the intrinsic mitochondrial pathway. The total alkaloids fraction of THH induced apoptosis by inhibiting Bcl-xL, Bcl-2, and XIAP and activating PARP and caspase-3, thereby inhibiting the growth of colon cancer cells in a dose-dependent manner in vitro (Jiang et al., 2014). Triptonide potently inhibited vasculogenic mimicry mediated by pancreatic cancer cells (Han et al., 2018). In addition, triptonide inhibited the epithelial-mesenchymal transition of gastric cancerassociated fibroblasts (GCAFs) by correcting abnormalities in microRNA expression and subsequently eliminating the epithelial-mesenchymal transition in gastric cancer cells (Wang et al., 2017). Moreover, a cytotoxicity of triptolide and 2-epilactone was observed, particularly in A549, DU145, KB, KBvin, and MDA-MB-231 human tumour cell lines, with $\mathrm{IC}_{50}$ values of $0.0012-0.1306 \mu \mathrm{M}$ in vitro (Li X.-L. et al., 2015). The mRNA and protein levels of CD147 and MMPs were reduced, and triptonide also inhibited the expression of caveolin-1, thereby inhibiting the invasion and migration of prostate cancer cells (Yuan et al., 2020).

Pancreatic cancer (PC) cell lines SNU-213, Capan-1 and Capan-2 exhibit different sensitivities to triptolide with $\mathrm{IC}_{50}$ values of $0.01,0.02$, and $0.0096 \mu \mathrm{M}$, respectively. Phosphorylation of Chk2 was more significant in SNU-213 sensitive to triptolide but, not in SNU-410 insensitive to triptolide, suggesting that the effect of triptolide on different PC cell lines may be related to gene expression (Liu L. et al., 2014; Kim et al., 2018). In addition, triptolide inhibited CRC growth through induction of cleavage and perinuclear translocation of 14-3-3e protein (Liu et al., 2012). Furthermore, triptolide dosedependently inhibited the proliferation of human scale-cell carcinoma SAS, human cervical carcinoma SKG-II, and human fibrosarcoma HT-1080 cells, an important target molecule in the antitumour effect of triptolide is phosphatidylinositol 3-kinase (PI3K). The reduction of PI3K activity leads to inhibition of tumour cell proliferation, which subsequently leads to enhanced JNK1 phosphorylation through Akt and/or PKC-independent pathways (Miyata et al., 2005).

As an important compound of $\mathrm{THH}$, celastrol exhibits tumour-inhibiting effects in a variety of tumour models, and its antitumour mechanisms have been demonstrated in various 
cancers in vitro (Li Z. et al., 2012; Lee et al., 2012). There are two main pathways by which celastrol induces apoptosis in cancer cell lines, namely, through the activation of intrinsic pathways (mitochondrial pathways) and extrinsic apoptotic pathways (death receptor pathways) (Mou et al., 2011). Apoptosis, paraptosis, and necrosis are modes of cell death induced by celastrol (Chen et al., 2011); the expression of ERa target genes was suppressed, celastrol also decreased the expression of ERa at the protein and mRNA levels in MCF7 and T47D human breast cancer cells, leading to cell cycle arrest and inhibition of breast cancer cell growth (Jang et al., 2011). Moreover, celastrol induced apoptosis by cleaving the PARP proteins, caspase-3, caspase- 9 , and caspase-8; increasing FasL and Fas expression; decreasing mitochondrial membrane potential; upregulating proapoptotic Bax expression; and downregulating antiapoptotic Bcl-2 (Mou et al., 2011). In addition, the activation of caspase- 3 also involved in the induces myeloma cell apoptosis, and celastrol inhibited NF- $\mathrm{kB}$ migration into the nucleus, and treatment of the human myeloma cell line U266 with celastrol induces cell cycle at the G1 phase followed by apoptosis (Tozawa et al., 2011). Moreover, celastrol suppressed the migration of AGS and YCC-2 cells in gastric tumour induced G1 arrest in cell-cycle populations, and increased phosphorylated AMPK levels after reducing the levels of AKT, mTOR, and S6K phosphorylation (Lee et al., 2014). In addition, celastrol can significantly reduce tumour nodules in the liver by decreasing DEN-induced MDM2 levels and activating the p53 pathway, thereby improving DEN-induced liver pathology (Chang et al., 2016). It also induces apoptosis in Bel-7402 cells by the mitochondrial apoptosis pathway (Li P.-P. et al., 2015). Moreover, it upregulates both the mRNA and protein levels of DR4 and DR5, which induce TRAIL/Apo-2 L-mediated apoptosis in cancer cells (Zhu et al., 2010; Lin et al., 2017).

In the last 10 years, given the increased accessibility of oncometabolites, the idea that cancer is a metabolic disorder has gradually emerged (Collins et al., 2017). In reports on colon cancer, many oncometabolites such as histidine, isoleucine, phenylalanine, tyrosine, threonine, glutamate, and pyruvate have been found to be closely related to cancer-associated metabolic pathways (Mishra and Ambs, 2015; Wishart et al., 2016). Treatment with triptolide may help to restore normal metabolite levels in these pathways. Triptolide increases isoleucine, plasma proline, methionine, 2-hydroxyisovalerate (2-HIV), low-density lipoprotein/very low-density lipoprotein (LDL/VLDL) and 2-hydroxyisobutyrate (2-HIB) levels, and reduces plasma pyruvate, 3-hydroxybutyric acid, and glutamine levels. Because 2-HIV, LDL/VLDL and 2-HIB are related to branched-chain amino acid metabolism, lactate and pyruvate metabolism, and cholesterol metabolism, respectively, the antitumour mechanism of triptolide may rely on correcting alterations in serine/glycine/methionine biosynthesis, branchedchain amino acid metabolism, and ketone body metabolism ( $\mathrm{Li}$ et al., 2019).

\section{Anti-Obesity and Insulin Resistance Effects}

Celastrol targets mitochondria, inhibits the inflammatory response and prevents obesity induced by specific diets in mice. Celastrol-administered mice at $100 \mu \mathrm{g} / \mathrm{kg}$ decrease food consumption and body weight via a leptin-dependent mechanism (Kyriakou et al., 2018). In 2015, the Umut Ozcan team at Harvard Medical School screened more than 1,000 compounds that reduce ER stress (insulin resistance is a major risk factor for obesity, and ER stress is an important cause of resistance) and found that celastrol can be used as a weight-loss drug. Obese mice treated with celastrol lost $45 \%$ of their body weight, and improved insulin sensitivity was observed. Thus, celastrol may exhibit potential therapeutic effects in various diseases, such as type 2 diabetes and fatty liver (Liu et al., 2015). The weight-loss mechanism of celastrol is mediated through interleukin 1 receptor 1 (IL1R1) (Feng X. et al., 2019), it has no effects on weight loss, diabetes or fatty liver in mice if IL1R1 is absent.

Mitochondrial dysfunction and inflammation tend to occur at high levels of fatty acid saturation in insulin-sensitive tissues (Hernández-Aguilera et al., 2013). Celastrol reduces the body weight of obese mice induced by a high leptin diet by up to $45 \%$, increases insulin sensitivity and energy expenditure, and inhibits food intake. Celastrol is a leptin sensitizer, but it has shown effects in leptin-deficient $(\mathrm{ob} / \mathrm{ob})$ and leptin receptor-deficient $(\mathrm{db} / \mathrm{db})$ mouse models (Liu et al., 2015). Palmitate-mediated insulin resistance could be blocked by celastrol by improving metabolic activity associated with mitochondrial function (Bakar et al., 2014). In addition, celastrol significantly reduced mitochondrial superoxide production; enhanced the cellular fatty acid oxidation rate, intracellular ATP content and mitochondrial membrane potential citrate synthase activity; increased levels of tricarboxylic acid cycle intermediates; improved mitochondrial function; increased mitochondrial DNA content, and inhibited oxidative DNA damage, and glucose uptake activity and enhances the expression of AMPK and GLUT4 proteins were also improved by decreasing the activation of NF- $\mathrm{KB}$ and PKCO (Abu Bakar et al., 2015; Abu Bakar and Tan, 2017).

Importantly, Celastrol showed an anti-IR activity, it was achieved by reducing miR-223, and celastrol re-upregulated the downregulation of miR-150 and miR-223 in HepG2 cells (human hepatocellular carcinoma cell lines) through the GLUT4 pathway, reversing palmitate-induced insulin resistance (Zhang X. et al., 2019). Celastrol treatment significantly enhanced tyrosine-612 phosphorylation of IRS-1 protein and decreased serine-307 in C3A hepatocytes, protecting cells from mitochondrial dysfunction and insulin resistance (Abu Bakar et al., 2017). Meanwhile, it also reduces serum malondialdehyde (MDA) and reactive oxygen species levels, increases antioxidant enzyme activities, reduces oxidative stress and improves lipid metabolism in a dose-dependent manner by alleviating oxidative damage, and inhibiting NADPH oxidase activity by improving ABCA1 expression. These actions inhibit increases in body weight and alleviate cardiovascular damage (Abu Bakar and Tan, 2017). The inhibition of negative regulators protein tyrosine phosphatase (PTP) 1B (PTP1B) and T cell PTP (TCPTP) in the hypothalamic arcuate nucleus (ARC) were also invovled in body weight reduction. The reversible noncompetitive binding of celastrol to these proteins is mediated by an allosteric pocket close to the active site (Kyriakou et al., 2018). 


\section{Antifertility Effect}

In 1986, reversible anti-fertility effects of TwHF extract in male rats were discovered, sparking global interest. The researchers performed bioassay-guided subfractionation of material extracted from plants and isolated a series of six male antifertility diterpene epoxides: triptolide, tripdiolide, triptolidenol, tripchlorolide, 16 hydroxytriptolide and T7/19 (Zhen et al., 1995). At the ED95 dosage levels, metamorphic spermatids as well as testicular and epididymal sperm excoriation and late spermatid basic nuclear protein turnover were inhibited. In addition, treatment with these compounds delayed spermatogenesis and sperm head-to-tail separation as well as microtubule, microfilament, and membrane damage (Zhen et al., 1995). Triptolide inhibited GATA4-mediated glycolysis by suppressing Sp1-dependent PFKP expression in SCs and induced testicular toxicity (Zhang et al., 2021b).

Oral $\mathrm{THH}$ reversibly induces infertility in men without significant side effects and does not affect libido or potency (Qian et al., 1988). Triptolide induced complete infertility in adult rats with minimal adverse effect on the testis, and it mainly targets epididymal sperm. No effects on testicular and accessory organ weights, tubular lumen volume and total number of Leydig cells, spermatogonia, tubule diameter, and number of Sertoli cells, pachytene (P) spermatocytes, and preleptotene (PL) were observed. Triptolide significantly reduced tubule volume and the number of round spermatids, making it an attractive lead agent as a post-testicular male contraceptive (Lue et al., 1998). We look forward to more reliable data to verify this possibility.

\section{Antiviral Effects}

Many natural products have been found to effectively inhibit unique enzymes and proteins that are essential for the viral life cycle (Vlietinck and Vanden Berghe, 1991; Baker et al., 1995). Hypoglaunine $\mathrm{A}$, hypoglaunine $\mathrm{B}$, triptonine $\mathrm{A}$, and hyponine $\mathrm{E}$ have represented compounds extracted and purified from $\mathrm{THH}$ roots with anti-HIV viral effects (Cheng et al., 2002). The total alkaloid extracts of THH showed potent anti-HSV-1 activity and low cytotoxicity in Vero cells (Tao et al., 2007). Triptobenzene J and quinone 21 have anti-A/PR/8/34 (H1N1) influenza virus (oseltamivir-resistance) activity with $\mathrm{EC}_{50}$ values of $38.6 \pm$ $10.7 \mu \mathrm{M}$, and $22.9 \pm 6.4 \mu \mathrm{M}$, respectively. Quinone 21 exhibited anti-A/Hong Kong/8/68 (H3N2) influenza virus (sensitivity) activity with an $\mathrm{EC}_{50}$ value of $21.6 \pm 0.6 \mathrm{Mm}$ (Wang et al., 2020).

Moreover, triptolide treatment inhibited macrophage infiltration; inhibited the overproduction of malondialdehyde (MDA), IL- 6, TNF- $\alpha$ and IL-1 $\beta$ in reperfusion myocardial tissue; and upregulated the activities of glutathione peroxidase (GPx), antioxidant superoxide dismutase (SOD), and glutathione (GSH), and the nuclear accumulation of $\mathrm{Nrf} 2$ and the activity of its downstream target haem oxygenase-1 (HO-1) were enhanced in ischaemic myocardial tissues (Yu et al., 2016). Additionally, triptolide significantly inhibited Epstein-Barr virus (EBV)-positive cellinduced tumour proliferation in vivo, and low-dose triptolide significantly decreased the half-life of EBV nuclear antigen 1, obviously reduced the expression of EBV nuclear antigen 1, and enhanced triptolide-induced apoptosis by activating the proteasome-ubiquitin pathway (Zhou et al., 2018). However, mitochondrial dysfunction, apoptotic damage, oxidative stress, and histopathological changes in the heart were noted in normal BALB/C mice treated with $1.2 \mathrm{mg} / \mathrm{kg}$ triptolide (Zhou et al., 2014). Therefore, the determination of safe dose is the key to the clinical application of triptolide.

Celastrol also showed effective activities in antivirals, it upregulated ERK1/2 phosphorylation, inhibited reactive oxygen species (ROS) generation, and improved endothelial cell activity and Ang II-mediated HUVEC injury by activating Nrf2 (Li M. et al., 2017); and the nuclear levels of Nrf2, nuclear levels of HSF-1 and cardiac GSH levels are also increased (Wang et al., 2015). Moreover, celastrol also inhibited hepatitis $\mathrm{C}$ virus (HCV) replication in both the $\mathrm{HCV}$ subgenomic and $\mathrm{HCVcc}$ infection systems with $\mathrm{EC}_{50}$ values of $0.37 \pm 0.022 \mathrm{mM}$ and $0.43 \pm 0.019 \mathrm{mM}$, respectively, the NS3/4A protease activity is inhibited, and further enhancing anti-HCV activity, thereby blocking $\mathrm{HCV}$ replication. Interestingly, celastrol showed synergistic effects in combination with the NS5B inhibitors sofosbuvir and interferon- $\alpha$ and the NS5A inhibitor daclatasvir targeting the JNK/Nrf2/HO-1 axis with celastrol presents a promising strategy against $\mathrm{HCV}$ infection that could serve as a potential supplement to block HCV replication (Tseng et al., 2017). This result suggests that synergistic use could be a topic in future research.

\section{Other Effects}

THH promoted the expression of Foxp3, increased the level of CD4+/CD25 + T cells, decreased the occurrence of aGVHD, and prolonged survival time in mice by regulating cytokine secretion (Li Z. Y. et al., 2013). Syringaresinol has significant protective activity against excitatory damage induced by sodium glutamate in SH-SY5Y neurons, and the mechanism potentially involves antioxidative stress and repair of mitochondrial function and DNA damage to significantly reduce sodium glutamate-induced neuronal apoptosis (Yan et al., 2019).

In recent years, researchers have gradually started to pay attention to the effect of triptolide in $\mathrm{AD}$. Regarding the neuroinflammatory pathology of the $\mathrm{AD}$ brain, triptolides potentially exert neuroprotective effects on synapses by partially inhibiting the mechanism of the $A \beta$-induced immunoinflammatory response, which may effectively slow the neurodegenerative process of AD (Nie et al., 2012). Triptolide inhibits $A \beta$-induced elevation of IL- $1 \beta$ and TNF- $\alpha$ levels in cultured rat microglia (Jiao et al., 2008). Triptolide promotes synaptophysin expression in hippocampal neurons in an AD cell model (Nie et al., 2012). Tripchlorolide, a novel analogue of triptolide, protected neuronal cells by blocking microglial inflammatory responses to oligomeric Abeta (1-42), inhibited nuclear translocation of nuclear NF- $\kappa \mathrm{B}$ without affecting I- $\kappa \mathrm{B} \alpha$ phosphorylation and inhibited $A \beta$-induced JNK phosphorylation, but not ERK or p38 MAPK (Pan et al., 2009). Triptolide also inhibits the upregulated expression of prostaglandin $\mathrm{E} 2$ and $\mathrm{IL}-1 \beta$ in lymphocytes and $\mathrm{AD}$ cell models (Tao et al., 1998; Li et al., 2011). 
TABLE 4 | Pharmacological effects of different compounds isolated from Tripterygium hypoglaucum in vitro studies.

\begin{tabular}{|c|c|c|}
\hline $\begin{array}{l}\text { Pharmacological } \\
\text { activity }\end{array}$ & Compound & Experimental design \\
\hline Anti-inflammatory & $\begin{array}{l}\text { THH } \\
\text { alkaloids }\end{array}$ & $\begin{array}{l}10 \mu \mathrm{g} \text { of total RNA isolated from THH-treated } \\
(40 \mu \mathrm{g} / \mathrm{ml}, 8 \mathrm{~h}) \text { and untreated } \mathrm{HL}-60 \text { cells }\end{array}$ \\
\hline- & Triptolide & $\begin{array}{l}\text { Corneal fibroblasts absence or presence of IL-1 } \\
(10 \mathrm{ng} / \mathrm{ml}) \text {, with or without triptolide }(30 \mathrm{nM}) \text { or } \\
\text { dexamethasone }(100 \mathrm{nM})\end{array}$ \\
\hline- & Triptolide & $\begin{array}{l}\text { Raw } 264.7 \text { cells stimulated with LPS }(50 \mathrm{ng} / \mathrm{ml}) \text { in } \\
\text { the presence or absence of triptolide }(30 \mu \mathrm{M}) \\
\text { for } 24 \mathrm{~h}\end{array}$ \\
\hline- & Triptolide & $\begin{array}{l}\text { Microglia were pre-treated with PBS, triptolide (10, } \\
30 \text {, or } 50 \mu \mathrm{M}) \text {, with or without Bay } 11-7,082 \text { for } \\
30 \text { min before LPS treatment ( } 10 \mathrm{ng} / \mathrm{ml}, 24 \mathrm{~h})\end{array}$ \\
\hline- & Triptolide & $\begin{array}{l}\text { TP-mmc }(15 \mu \mathrm{M}) \text { with or without TP }(1.2,12,15 \text {, } \\
30 \mu \mathrm{M}) \text { was added to RAW } 264.7 \text { cells (middle } \\
\text { panel: bar, } 50 \mu \mathrm{M}) \text { for } 2 \mathrm{~h}\end{array}$ \\
\hline- & Celastrol & $\begin{array}{l}\text { fibroblast-like synoviocytes (FLSs) were treated with } \\
\text { celastrol }(0.05,0.1,0.2,0.4 \text { and } 0.8 \mathrm{mM}) \text { for } 24 \mathrm{~h}\end{array}$ \\
\hline- & Celastrol & $\begin{array}{l}\text { HaCaT cells were incubated with celastrol }(0,0.1 \text {, } \\
0.5,1 \mu \mathrm{g} / \mathrm{ml}) \text { for } 1 \mathrm{~h} \text {, and stimulated with IFN-c } \\
(100 \mathrm{U} / \mathrm{ml}) \text { for } 4 \mathrm{~h} \text { (for RNA) or } 12 \mathrm{~h} \text { (for protein) }\end{array}$ \\
\hline- & Celastrol & $\begin{array}{l}\text { HaCaT cells were pretreated with DPI }(10 \mu \mathrm{M}) \text {, NAC } \\
(20 \mathrm{mM}) \text { or EUK } 134(50 \mu \mathrm{M}) \text { for } 1 \mathrm{~h} \text {, and then } \\
\text { incubated with celastrol }(1 \mu \mathrm{g} / \mathrm{ml}) \text { for } 6 \mathrm{~h} \text { (for RNA) or } \\
12 \mathrm{~h} \text { (for protein) }\end{array}$ \\
\hline- & Celastrol & $\begin{array}{l}\text { RAW264.7 cells were treated with } 0-1 \mu \mathrm{M} \text { of } \\
\text { celastrol for } 24 \mathrm{~h}\end{array}$ \\
\hline- & Celastrol & $\begin{array}{l}\text { BV-2 cells were pre-treated with various } \\
\text { concentrations of celastrol }(1,10 \text { and } 100 \mathrm{nM}) \text { for } \\
30 \mathrm{~min} \text { prior to stimulation with LPS }(10 \mathrm{ng} / \mathrm{ml}) \text { for } \\
6 \mathrm{~h} \text { (for TNF- } \alpha \text { ) and } 24 \mathrm{~h} \text { (for IL-1 } \beta \text { ) }\end{array}$ \\
\hline- & Celastrol & $\begin{array}{l}\text { Jurkat T cells were preincubated for } 30 \text { min with } \\
\text { celastrol }(0,0.3,1 \mu \mathrm{g} / \mathrm{ml}) \text { and followed by the } \\
\text { stimulation with of TNF-a }(20 \mathrm{ng} / \mathrm{ml}) \text { or PMA ( } 50 \mathrm{ng} / \\
\mathrm{ml}) \text { for } 90 \mathrm{~min}\end{array}$ \\
\hline- & Celastrol & $\begin{array}{l}\text { Neutrophils were pre-incubated with different doses } \\
\text { of celastrol }(0.5-20 \mu \mathrm{M}) \text { or vehicle only at RT for } \\
45 \text { min }\end{array}$ \\
\hline Immuno-suppression & Triptolide & $\begin{array}{l}\text { Monocytes were cultured for } 5 \text { days in the presence } \\
\text { of various concentrations }(1-20 \mathrm{ng} / \mathrm{ml}) \text { of triptolide } \\
\text { and Dex }(10-8-10-6 \mathrm{M})\end{array}$ \\
\hline- & Triptolide & $\begin{array}{l}\text { LPS }(100 \mathrm{ng} / \mathrm{ml}) \text {-stimulated } \text { U937 cells were treated } \\
\text { with or without triptolide }(12.5 \mathrm{nM})\end{array}$ \\
\hline- & Celastrol & $\begin{array}{l}\text { Bone marrow-derived macrophages were pre- } \\
\text { treated with celastrol }(0.1,0.5 \text { and } 1 \mu \mathrm{M}) \text { for } 1 \mathrm{~h} \text { and } \\
\text { treated with Alexa Fluor } 594 \text { conjugated with LPS } \\
(1.5 \mu \mathrm{g} / \text { sample) for } 30 \mathrm{~min}\end{array}$ \\
\hline- & Celastrol & $\begin{array}{l}\text { Purified CD4+CD25- T cells were treated in the } \\
\text { presence or absence (control) of Celastrol }(200 \mathrm{nM})\end{array}$ \\
\hline- & Triptolide & $\begin{array}{l}\text { Confluent synovial cells were treated with } \\
\text { recombinant human interleukin-1a (IL-1a; } 1 \mathrm{ng} / \mathrm{ml}) \text {, } \\
\text { dexamethasone (Dex), and/or triptolide } \\
(2.8-140 \mathrm{nM}) \text { at the indicated concentrations }\end{array}$ \\
\hline- & Triptolide & $\begin{array}{l}\text { Human monocytes were cultured for } 7 \text { days with G4 } \\
\text { medium in the presence of TPT (D2-7, 0.5-10 nM) or } \\
\text { medium alone }\end{array}$ \\
\hline \multirow[t]{2}{*}{-} & Triptolide & $\begin{array}{l}\text { C57BL/ } 6 \text { mouse bone marrow cells were cultured } \\
\text { with mGM-CSF and } \mathrm{mlL}-4 \text {, and triptolide }(0,1,5,10 \text {, } \\
20,50 \text {, and } 100 \mathrm{ng} / \mathrm{ml}) \text { added on day } 3 \text { of culture } \\
\text { (Trip-DC) }\end{array}$ \\
\hline & Triptolide & \\
\hline
\end{tabular}

References action

Tgenes related to the NF- $\mathrm{KB}$ signalling pathway and Zhuang et al. cell apoptosis (such as NFKBIB, PRG1 and B2M), $\downarrow$ C- $\quad$ (2004) myc binding protein and apoptosis-related cysteine proteases caspase- 3 and caspase- 8

\IL-1, IL-8 and MCP-1

Lu et al. (2005)

$\downarrow$ DNA binding activity of NF- $\mathrm{BB}, \downarrow N \mathrm{NO}$ production, $\downarrow$ phosphorylation of $\mathrm{C}$-Jun $\mathrm{NH}(2)$-terminal kinase (JNK)

\p38-NF-kappaB-COX-2-PGE(2) and JNK-PGE(2)

\TAK1-TAB1 complex kinase activity

Kim et al. (2004)

Gong et al.

(2008)

Lu et al. (2014)

$\downarrow$ MMP-9 promoter activity, $\downarrow$ TLR4/MyD88/NF-кB pathway, $\downarrow$ FLS migration and invasion \IFN- $\gamma$-induced ICAM-1 mRNA and protein expression

Li et al. (2013a)

Seo et al. (2010)

१ROS-ERK/p38-Nrf2-ARE, $\uparrow \mathrm{HO}-1$

Seo et al. (2011)

$\downarrow$ nitric oxide synthase and cyclooxygenase-2, $\downarrow$ MPO activity, $\downarrow$ LL-6 and TNF- $\alpha$

$\downarrow$ expression of mRNAs of iNOS and cytokines; $\downarrow N O$, IL- $1 \beta$ and TNF- $\alpha$; $\downarrow$ ERK $1 / 2$ phosphorylation and NF$\kappa \mathrm{B}$ activation

$\downarrow \mid \mathrm{KK}$ activity and IKK $\beta$ activity, $\downarrow \mathrm{Bfl}-1 / \mathrm{A} 1$ expression

Lee et al. (2006)

$\downarrow$ neutrophil oxidative burst and NET formation, \SYK- Yu et al. (2015) MEK-ERK-NF- $\mathrm{kB}$ signalling cascade

$\downarrow$ CD1a, CD40, CD80, CD86 and HLA-DR expression; $\uparrow C D 14$ expression

Zhu et al. (2005)

$\downarrow$ TREM-1 and DNAX-associated protein (DAP)12, $\downarrow$ activation of JAK2 and STAT3, $\downarrow$ TNF- $\alpha, \mathrm{IL}-1 \beta$ and IL-6

$\downarrow T N F-\alpha, I L-6, I L-12$, and IL-1 $\beta, \downarrow$ LPS binding to the Lee et al. (2015) TLR4/MD2 complex

$\downarrow$ mTOR, HIF-1 $\alpha$, c-Myc and Akt expression in Th17 cells, $\uparrow F A O$ of lipids by upregulating CPT1A and

Zhang et al. AMPKa expression in iTreg cells

$\downarrow \| \mathrm{L}-1 \alpha$-induced production of proMMP- 1 and -3, $\uparrow \mathrm{LL}-\quad$ Lin et al. (2001) 1alpha-induced gene expression and production of TIMP-1 and -2

$\downarrow$ production of IL-12 p70

Chen et al. (2005)

activation of $\mathrm{p38}$, \activation of caspase 3

Liu et al. (2004)

Liu et al. (2008)

(Continued on following page) 
TABLE 4 | (Continued) Pharmacological effects of different compounds isolated from Tripterygium hypoglaucum in vitro studies.

$\begin{array}{llcc}\text { Pharmacological } & \text { Compound } & \text { Experimental design } & \text { Molecular targets/mode of } \\ \text { activity } & & \text { action }\end{array}$

\begin{tabular}{|c|c|c|}
\hline \multirow[b]{2}{*}{ Antitumour effect } & & \\
\hline & $\begin{array}{l}\text { Total } \\
\text { alkaloids }\end{array}$ & $\begin{array}{l}\text { JB6 Cl41 cells were suspended containing } 10 \% \\
\text { FBS, } 10 \mu \mathrm{M} \text { TPA with or without THHta } \\
(1.25-10 \mu \mathrm{g} / \mathrm{ml})\end{array}$ \\
\hline- & Triptonide & $\begin{array}{l}\text { treatment of the pancreatic cancer cell lines } \\
\text { Patu8988 and Panc1 with triptonide at the doses of } \\
0-20 \mathrm{nM}\end{array}$ \\
\hline- & Triptolide & $\begin{array}{l}\text { PC-3 and DU145 cells were incubated with triptolide } \\
(0,25,50 \mathrm{nM}) \text { for } 24 \mathrm{~h}\end{array}$ \\
\hline- & Triptolide & $\begin{array}{l}\text { Malignant (BxPc-3, MIA-PaCa2 and AsPC-1) and } \\
\text { nonmalignant (pancreatic ductal cells and MSC) cells } \\
\text { grown under normoxia or hypoxia in the presence or } \\
\text { absence of triptolide ( } 20 \mathrm{nM})\end{array}$ \\
\hline- & Triptolide & $\begin{array}{l}\text { Urothelial cancer cells were treated with CDDP at the } \\
\text { concentration corresponding to IC25 ( } 30 \mathrm{mM}) \text { with } \\
\text { or without } 1 \mathrm{~h} \text { pretreatment of } 30 \mathrm{nM} \text { triptolide } \\
\text { for } 12 \mathrm{~h}\end{array}$ \\
\hline- & Triptolide & $\begin{array}{l}\text { The JNK1 knockdown cells were treated with } \\
\text { triptolide }(14-56 \mathrm{nM}) \text { for } 15 \mathrm{~h}\end{array}$ \\
\hline- & Celastrol & $\begin{array}{l}\text { SO-Rb } 50 \text { cells were treated with celastrol } \\
\text { nanoparticles }(0-54.4 \mu \mathrm{g} / \mathrm{ml}) \text { and the same dosage } \\
\text { of PEG-b-PCL micelles without celastrol for } 48 \mathrm{~h}\end{array}$ \\
\hline
\end{tabular}

- Celastrol A549 cells were treated with celastrol $(0-8 \mu \mathrm{M})$ at the

indicated concentration for 24,48 , and $72 \mathrm{~h}$

Celastrol

Celastrol

Celastrol

Anti-obesity and insulin Celastrol resistance

$-\quad$ Celastro

Antiviral effect

Triptolide

$\mathrm{H} 1650$ cells were collected for apoptosis analysis at $24 \mathrm{~h}$ after the treatment of celastrol $(0.5,1,2,4 \mu \mathrm{M})$ $\mathrm{H} 1299$ cells were treated with or without $4 \mu \mathrm{M}$ celastrol in the absence or presence of $50 \mu \mathrm{M}$ Z-VAD for $24 \mathrm{~h}$

Human myeloma cell line U266 cells were treated with celastrol $(0.25$ and $0.5 \mu \mathrm{M})$ for the indicated times (0-48 h)

Fully differentiated 3T3-L1 adipocytes were

incubated with different doses of oligomycin $(5,10$, 20 and $30 \mu \mathrm{g} / \mathrm{ml})$ and celastrol $(5,10,20$ and $30 \mu \mathrm{M})$ in DMSO for $48 \mathrm{~h}$

C3A human hepatocytes were exposed to various concentration (10-50 nM) of celastrol in the serumfree media for $48 \mathrm{~h}$

Myoblasts were treated with different concentrations $(10,20,30,40,50$ and $60 \mathrm{nM})$ of celastrol were prepared and mixed with $0.1 \%(\mathrm{~V} / \mathrm{V}) \mathrm{DMSO}$. The vehicle consisted of an equal amount of DMSO was used as a control

HONE1/Akata, HK1/Akata, C666-1, and CNE1 cells were placed in $35 \mathrm{~mm}$ culture dishes (500 cells/ dish) and cultured in standard medium with DMSO control $(0.01 \%)$ or triptolide $(1,2$, or $5 \mathrm{nM})$ for 2 weeks

- $\quad$ Triptolide Human umbilical vascular endothelial cells (HUVEC) were trested with or without brusatol $(40 \mathrm{nmol} / \mathrm{L}) /$ celastrol (50 nmol/L)/Angll( $400 \mathrm{nmol} / \mathrm{L})$ for $24 \mathrm{~h}$

- Celastrol The transfected ava5 cells were treated with

celastrol $(0,0.2,0.3,0.4,0.5 \mu \mathrm{M})$ for 3 days

Other effects Triptolide The model microglial group was treated with $A \beta 1-40$ (20 $\mathrm{\mu g} / \mathrm{ml})$. The low-dose triptolide microglial group was treated with $A \beta 1-40(20 \mu \mathrm{g} / \mathrm{ml})$ and triptolide $(5 \mu \mathrm{g} / \mathrm{ml})$. The high-dose triptolide microglial group $\downarrow \mathrm{CD} 80$ and CD86 expression on IFN-gamma-

(500 kU/L) and LPS- (1 mg/L) activated THP-1 cells, IIL-12p40 and IL-12p70

Tactivation of caspase-3 and PARP, $\downarrow$ Bcl-2, Bcl-xL Jiang et al. (2014) and XIAP

IVE-cadherin and CXCL2 genes

Han et al. (2018)

$\downarrow R N A$ polymerase activity, $\downarrow C D C 25 A$, and MYC and Src oncogenes

」epithelial-mesenchymal transition (EMT) and CSC Liu et al. (2014a) features

\CDDP-induced p53 transcriptional activity

Matsui et al. (2008)

$\downarrow$ phosphatidylinositol 3-kinase (PI3K) activity, $\uparrow$ C-Jun $\mathrm{NH}(2)$-terminal kinase 1 (JNK1)

Miyata et al. (2005) $\downarrow$ elevated levels of ALT, AST, ALP and AFP; \antiapoptotic $\mathrm{Bcl}-2$ and $\mathrm{Bcl}-\mathrm{xl}$; induced the expression of pro-apoptotic Bax, cytochrome C, PARP and caspases

Texpression of pro-apoptotic Bax, \anti-apoptotic $\mathrm{Bcl}-2$ and Akt phosphorylation

$\downarrow$ EGFR and AKT

Li et al. (2012b)

$\uparrow$ cleavage of PARP, caspase 9 and caspase 3

Mou et al. (2011)

Fan et al. (2014)

Chen et al. (2011)

$\uparrow$ caspase-3 and NF-kB pathways

Tozawa et al. (2011)

$\downarrow$ oxidative DNA damage, protein carbonylation and Bakar et al. lipid peroxidation

(2014)

\PA-induced GLUT4 and IRS1

Abu Bakar et al. (2017)

$\uparrow N F-\kappa B$ p65, c-Jun NH(2)-terminal kinase (JNK)

Abu Bakar and signalling pathways, $\uparrow I L-8, \mathrm{IL}-6, \mathrm{TNF}-\alpha$ and CRP

Tan (2017)

$\downarrow$ ratio of Bax/Bcl-2, †activated caspase-3 and Nrf2

Zhou et al. (2018)

$\uparrow$ caspase-9-dependent apoptosis

Li et al. (2017a)

$\downarrow$ iNOS, TNF- $\alpha$, and NF-kB phospho-p65 expression, †nuclear levels of Nrf2 and HSF-1

Tseng et al.

(2017)

Nie et al. (2012) 
TABLE 4 | (Continued) Pharmacological effects of different compounds isolated from Tripterygium hypoglaucum in vitro studies.

\begin{tabular}{|c|c|c|c|c|}
\hline $\begin{array}{l}\text { Pharmacological } \\
\text { activity }\end{array}$ & Compound & Experimental design & $\begin{array}{l}\text { Molecular targets/mode of } \\
\text { action }\end{array}$ & References \\
\hline & & $\begin{array}{l}\text { was treated with } A \beta 1-40(20 \mu \mathrm{g} / \mathrm{ml}) \text { and triptolide } \\
(25 \mu \mathrm{g} / \mathrm{ml})\end{array}$ & & \\
\hline- & Triptolide & $\begin{array}{l}\text { RASF, HM, HFF, or U937 cells were incubated } \\
\text { overnight with or without LPS }(2 \mu \mathrm{g} / \mathrm{ml}) \text { in the } \\
\text { presence or absence of the indicated concentrations } \\
\text { of T2 }(1,2,4 \mu \mathrm{g} / \mathrm{ml}) \text {, triptolide }(1,2,4 \mathrm{ng} / \mathrm{ml}) \text {, DEX } \\
(0.1,1,10 \mu \mathrm{M}) \text {, or Indo }(0.01,0.1 \mu \mathrm{g} / \mathrm{ml})\end{array}$ & $\begin{array}{l}\downarrow \text { protein levels of inducible nitric oxide synthase } \\
\text { (iNOS) and cyclooxygenase- } 2 \text { (COX-2) }\end{array}$ & Tao et al. (1998) \\
\hline
\end{tabular}

\section{Pharmacokinetics}

Over the years, scholars have conducted numerous studies on the pharmacodynamics of THH, but studies on the pharmacokinetics of THH compounds in animals, especially those administered intravenously, are limited. Antitumour pharmacodynamics and toxicological studies of triptolide are closely related to the pharmacokinetics and tissue distribution of triptolide, which are important components of new drug evaluation studies. Oral triptolide is rapidly and highly absorbed and distributed in the liver, heart, spleen, lung and kidney. Biotransformation of triptolide in rats includes hydroxylation, sulfate, glucuronide, $\mathrm{N}$-acetylcysteine (NAC) and glutathione (GSH) conjugation and combinations of these pathways. Less than $4 \%$ of triptolide was recovered from the faces, bile and urine within $24 \mathrm{~h}$. After repeating the dosage, triptolide was eliminated quickly without accumulation in vivo. As a substrate for P-glycoprotein (P-gp) and CYP3A4, triptolide could have clinically significant pharmacokinetic interactions with protein substrates/inhibitors (Song et al., 2019). After injection of three doses $(100 \mu \mathrm{g} / \mathrm{kg}$, $200 \mu \mathrm{g} / \mathrm{kg}, 300 \mu \mathrm{g} / \mathrm{kg}$ ) of triptolide into the veins of rats, the corresponding $t_{1 / 2 \alpha}$ of each subsequent dose group was: 0.033 , 0.021 , and $0.026 \mathrm{~h}$, respectively, and the $t 1 / 2 \beta$ values were 0.753 , 0.630 , and $0.574 \mathrm{~h}$. The AUC was related to the dose, and the compartmental model was a two-compartment model. After intravenous injection of an effective dose $(200 \mu \mathrm{g} / \mathrm{kg})$ of triptolide in rats, rapid and extensive tissue distribution was observed. After 5 min of administration, the highest triptolide levels were noted in lung tissue followed by liver, kidney, heart, brain, spleen, small intestine, gonads, skeletal muscle, and stomach. Fifteen min after administration, the drug concentrations in all tissues decreased with higher concentrations in the lung, kidney, heart and liver. The distribution order is similar to that noted $5 \mathrm{~min}$ after administration. One hour after administration, the drug concentration in each tissue decreased significantly, and high drug concentration was still maintained in the liver and small intestine (Shao et al., 2007).

Celastrol exhibited linearity in the concentration range of $0.05-5 \mu \mathrm{g} / \mathrm{ml}$ with $\mathrm{R}^{2}$ of 0.999 . Rats were intravenously (IV) administered $1 \mathrm{mg} / \mathrm{kg}$ of pure CL in PEG 300 solution, which resulted in a maximum concentration $\left(\mathrm{C}_{\max }\right)$ value of $0.17 \mu \mathrm{g} / \mathrm{ml}$ at $5 \mathrm{~min}$ following administration (Onyeabor et al., 2019). After oral administration of Tripterygium wilfordii tablets ( 1 tablet $/ \mathrm{kg}$ ) to beagle dogs, the changes in plasma celastrol levels followed a one-compartment model $(\mathrm{w}=1 / \mathrm{cc})$, and the main pharmacokinetic parameters were $\mathrm{C}_{\max }(35.64 \pm 9.540) \mu \mathrm{g} \cdot \mathrm{L}^{-1}$, $\operatorname{Tmax}(2.62 \pm 0.69) \mathrm{h}, \mathrm{T} 1 / 2(2.93 \pm 0.29) \mathrm{h}, \mathrm{CL}(0.308 \pm 0.056) \mathrm{Lkg}$

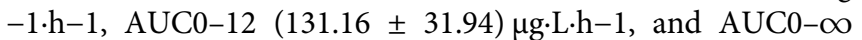
$(142.83 \pm 37.57) \mu \mathrm{g} \cdot \mathrm{L} \cdot \mathrm{h}-1$ (Zhang et al., 2016). Glycyrrhizin significantly decreased the plasma concentration (from $64.36 \mathrm{ng} / \mathrm{ml}$ to $38.42 \mathrm{ng} / \mathrm{ml}$ ) and AUC0-t (from 705.39 to $403.43 \mu \mathrm{g} \mathrm{h} / \mathrm{L}$ ) of celastrol in rats, and increased the efflux ratio of celastrol (4.02 vs. 6.51). Moreover, glycyrrhizin significantly increased the intrinsic clearance rate of celastrol from $20.3 \pm 3.37$ to $38.8 \pm 4.18 \mu \mathrm{L} / \mathrm{min} / \mathrm{mg}$ proteins (Yan et al., 2017).

\section{Toxicity}

The targets of toxicity were closely associated with the p53 signalling pathway, PI3K-Akt signalling pathway and other pathways. Although THH has multiple phytochemical activities and pharmacological effects, it is also limited in clinical application given its toxicities associated with multiple targets (Xu et al., 2004). Although triptolide has attracted remarkable efficacy against diseases, the safety margin of the triptolide medication dose is very narrow, and the accumulation of triptolide in the body can lead to severe hepatotoxicity, renal toxicity, and reproductive toxicity (Sun et al., 2013; Kong et al., 2015; Ma et al., 2015). Therefore, dose control is particularly important in clinical treatment (Figure 5).

Triptolide mainly causes abnormal purine and pyrimidine metabolites in the body through the metabolism of hypoxanthine, allantoic acid, ADA and other proteins. The mechanism of triptolide-induced liver injury exhibits an important relationship with oxidative stress, and excessive ROS and anionic peroxide production, depletion, autophagy, hepatocyte apoptosis, and suppression of antioxidant enzyme activities are the main causes of oxidative stress (Fu et al., 2011; Xi et al., 2017; Wei et al., 2019). Thus, hepatocyte injury is mainly caused by high levels of ROS and reactive nitrogen species (RNS) inhibiting sodium, ATPase, and calcium pump activities in the cell membrane, resulting in decreased mitochondrial membrane potential (MMP) and release of the apoptosis factor caspase-3 (Li J. et al., 2014; Wang Y. et al., 2018; Tabeshpour et al., 2018; Feng Z. et al., 2019; Yuan et al., 2019b; Hasnat et al., 2019). Moreover, triptolide significantly increased serum ALP, AST, and ALT levels; increased hepatic MDA, IL- 6 , TNF- $\alpha$, IFN- $\gamma$, and IL$1 \beta$ levels, induced nuclear translocation of NF- $\mathrm{kB}$; and decreased 
TABLE 5 | Pharmacological effects of different compounds isolated from Tripterygium hypoglaucum in vivo studies.

\begin{tabular}{|c|c|c|c|c|c|c|}
\hline $\begin{array}{l}\text { Pharmacological } \\
\text { activity }\end{array}$ & Compound & Experimental design & $\begin{array}{c}\text { Molecular targets/mode } \\
\text { of action }\end{array}$ & $\begin{array}{l}\text { Duration of } \\
\text { treatment }\end{array}$ & $\begin{array}{c}\text { Route of } \\
\text { administration }\end{array}$ & References \\
\hline Anti-inflammation & Triptolide & $\begin{array}{l}\text { Triptolide ( } 8,16 \text { and } 32 \mathrm{mg} / \\
\text { (kg day); } \mathrm{n}=16 \text {, } \\
\text { respectively), } \\
\text { dexamethasone ( } 1 \mathrm{mg} /(\mathrm{kg} \\
\text { every } 2 \text { days); } n=16) \text { or } \\
\text { vehicle }(n=20)\end{array}$ & $\begin{array}{l}\downarrow \text { metalloproteinases- } 13 \text { and } \\
-3, \downarrow \text { COX- } 2 \text { and PGE(2), } \downarrow \downarrow L-1 \beta \text {, } \\
\text { TNF- } \alpha \text { and IL- } \\
6, \uparrow \text { metalloproteinases- } 1 \text { and }-2\end{array}$ & $\begin{array}{l}\text { Daily for a period of } \\
21 \text { days }\end{array}$ & Oral administration & $\begin{array}{l}\text { Lin et al. } \\
(2007)\end{array}$ \\
\hline- & Triptolide & $\begin{array}{l}\text { Triptolide }(0.1 \mathrm{mg} / \mathrm{kg} / \mathrm{d}) \\
\text { dissolved in } 5 \% \text { dimethyl } \\
\text { sulfoxide was } \\
\text { intraperitoneally injected } \\
\text { into the } \mathrm{SCl} \text { rats }\end{array}$ & 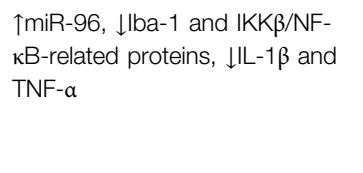 & $\begin{array}{l}\text { Continued for } \\
\text { successive } 10 \text { days }\end{array}$ & $\begin{array}{l}\text { Intraperitoneal } \\
\text { injection }\end{array}$ & $\begin{array}{l}\text { Huang et al. } \\
(2019)\end{array}$ \\
\hline- & Tripterine & $\begin{array}{l}\text { tripterine }(5,10 \text { and } 20 \mathrm{mg} \\
\mathrm{kg}-1 \mathrm{day}-1) \text {, or prednisone } \\
(10 \mathrm{mg} \mathrm{kg}-1 \text { day-1); } 0.5 \% \\
\text { CMC solution as vehicle- } \\
\text { treated group }\end{array}$ & $\begin{array}{l}\downarrow \text { lgG and delayed-type } \\
\text { hypersensitivity (DTH), } \downarrow \text { IL-1 } \beta \\
\text { and TNF- } \alpha\end{array}$ & 5 days & $\begin{array}{l}\text { Intragastrical } \\
\text { administration }\end{array}$ & Li et al. (2008) \\
\hline- & Celastrol & $\begin{array}{l}1 \mu \mathrm{g} / \mathrm{g} \text { Celastrol or } 2 \mu \mathrm{g} / \mathrm{g} \\
\text { digoxin were administrated } \\
\text { at adjuvant-induced arthritis } \\
\text { (AIA) rats }\end{array}$ & $\downarrow I L-1 \beta$ and TNF & $\begin{array}{l}\text { After } 4 \text { days (early } \\
\text { treatment group) and } \\
\text { after } 11 \text { days (late } \\
\text { treatment group) of } \\
\text { disease induction }\end{array}$ & $\begin{array}{l}\text { Intraperitoneal } \\
\text { injection }\end{array}$ & $\begin{array}{l}\text { Cascão et al. } \\
\text { (2012) }\end{array}$ \\
\hline- & Celastrol & $\begin{array}{l}\text { Saline }(20 \mu \mathrm{L}) \text { containing } \\
4 \mu \mathrm{g} \text { of SPLA2IIA with } \\
\text { celastrol }(1,10,30 \mu \mathrm{M} \text { and } \\
100 \mu \mathrm{M}) / \text { vehicle was } \\
\text { injected into the intra- } \\
\text { plantar surface of the right } \\
\text { hind footpad of mice }\end{array}$ & $\begin{array}{l}\downarrow \text { sPLA2IIA, 5-LOX and COX-2 } \\
\text { enzymes }\end{array}$ & $\begin{array}{l}\text { After } 45 \text { min, mice were } \\
\text { anaesthetized with } \\
\text { pentobarbitone } \\
(30 \mathrm{mg} / \mathrm{kg} \text {, i.p. }) \text { and } \\
\text { euthanized }\end{array}$ & $\begin{array}{l}\text { Injected into the } \\
\text { intra-plantar surface } \\
\text { of the right hind } \\
\text { footpad of mice }\end{array}$ & $\begin{array}{l}\text { Joshi et al. } \\
\text { (2016) }\end{array}$ \\
\hline- & Celastrol & $\begin{array}{l}\text { Hepa1- } 6 \text { single-cell } \\
\text { suspension cells }(2 \times 107 / \\
\text { ml) were injected } \\
\text { subcutaneously at a volume } \\
\text { of } 0.1 \mathrm{ml} \text { in the right flank of } \\
\text { each mouse }\end{array}$ & $\begin{array}{l}\downarrow \text { AKT pathway and VEGF } \\
\text { autocrine system }\end{array}$ & $\begin{array}{l}21 \text { days of } \\
\text { administration }\end{array}$ & $\begin{array}{l}\text { Intraperitoneal } \\
\text { injection }\end{array}$ & $\begin{array}{l}\text { Zhang et al. } \\
\text { (2019a) }\end{array}$ \\
\hline $\begin{array}{l}\text { Immuno- } \\
\text { suppression }\end{array}$ & $\mathrm{THH}$ & $\begin{array}{l}\text { C57BL/ } 6 \text { mice were used } \\
\text { to model CIA mice received } \\
\text { THH } 420 \mathrm{mg} / \mathrm{kg} / \text { day or the } \\
\text { same amount of normal } \\
\text { saline (NS) }\end{array}$ & $\begin{array}{l}\downarrow T N F-\alpha \text {, IFN- } \gamma \text {, and IL-17A } \\
\text { mRNA and protein levels; } \downarrow N F- \\
\text { кB-STAT3-IL-17 pathway }\end{array}$ & 20 days & $\begin{array}{l}\text { Intragastrical } \\
\text { administration }\end{array}$ & $\begin{array}{l}\text { Zhou et al. } \\
\text { (2020) }\end{array}$ \\
\hline- & Celastrol & $\begin{array}{l}\text { CIA mice were treated } \\
\text { intraperitoneally (IP) with } \\
\text { celastrol in phosphate } \\
\text { buffered saline (PBS; } \\
3 \mathrm{mg} / \mathrm{kg} \text { ) or PBS alone }\end{array}$ & $\begin{array}{l}\downarrow \text { osteoclastic genes (Trap, Ctsk, } \\
\text { Ctr, Mmp-9) and transcription } \\
\text { factors (c-Fos, C-Jun and } \\
\text { NFATc1), } \downarrow N F-\kappa B \text { and MAPK } \\
\text { phosphorylation }\end{array}$ & 15 days & $\begin{array}{l}\text { Intraperitoneal } \\
\text { injection }\end{array}$ & $\begin{array}{l}\text { Gan et al. } \\
\text { (2015) }\end{array}$ \\
\hline- & Triptolide & $\begin{array}{l}\mathrm{ClA} \text { rats were treated with } \\
\text { triptolide }(11-45 \mu \mathrm{g} / \mathrm{kg} / \text { day }) \\
\text { starting on the day } 1 \text { after } \\
\text { first immunization }\end{array}$ & $\begin{array}{l}\downarrow \text { Matrigel-induced cell adhesion } \\
\text { of HFLS-RA and HUVEC, } \downarrow \text { TNF- } \\
\text { a, IL-17, VEGF, VEGFR, Ang-1, } \\
\text { Ang-2 and Tie2, } \downarrow \text { IL } 1-\beta \text {-induced } \\
\text { ERK phosphorylation and p38 } \\
\text { and JNK protein levels }\end{array}$ & $\begin{array}{l}\text { Daily for a period of } \\
28 \text { days from day } 1 \text { to } \\
\text { day } 28 \text { of first } \\
\text { immunization }\end{array}$ & $\begin{array}{l}\text { Oral administration } \\
\text { intragastrically using } \\
\text { syringe feeding }\end{array}$ & $\begin{array}{l}\text { Kong et al. } \\
\text { (2013) }\end{array}$ \\
\hline- & Celastrol & $\begin{array}{l}\text { Female Sprague Dawley } \\
\text { rats were treated by } \\
\text { celastrol ( } 1 \mathrm{mg} / \mathrm{kg} / \text { day, i.p.) }\end{array}$ & $\begin{array}{l}\uparrow I L-10, \downarrow T N F-\alpha \text {, } \\
\text { \immunohistochemical } \\
\text { expression of TLR2 and CD3+ } \\
\text { T-lymphocytic count }\end{array}$ & 32 days & $\begin{array}{l}\text { Intraperitoneal } \\
\text { injection }\end{array}$ & $\begin{array}{l}\text { Abdin and } \\
\text { Hasby, (2014) }\end{array}$ \\
\hline Antitumour effect & Celastrol & $\begin{array}{l}\text { C57BL/6N mice were } \\
\text { treated with } 1 \mathrm{mg} / \mathrm{kg} \text { of } \\
\text { celastrol, } 3 \mathrm{mg} / \mathrm{kg} \text { of } \\
\text { celastrol, or a vehicle } \\
\text { control. Celastrol was } \\
\text { dissolved in vehicle (10\% } \\
\text { DMSO, } 70 \% \text { Cremophor/ } \\
\text { ethanol (3:1), and } \\
20 \% \text { PBS) }\end{array}$ & $\begin{array}{l}\uparrow R O S-m e d i a t e d \text { caspase- } \\
\text { dependent apoptosis; } \downarrow \text { PI3K/ } \\
\text { AKT/mTOR signalling }\end{array}$ & 20 days & $\begin{array}{l}\text { Oral gavage every } \\
2 \text { days }\end{array}$ & $\begin{array}{l}\text { Lee et al. } \\
(2012)\end{array}$ \\
\hline
\end{tabular}


TABLE 5 | (Continued) Pharmacological effects of different compounds isolated from Tripterygium hypoglaucum in vivo studies.

\begin{tabular}{|c|c|c|c|c|c|c|}
\hline $\begin{array}{l}\text { Pharmacological } \\
\text { activity }\end{array}$ & Compound & Experimental design & $\begin{array}{l}\text { Molecular targets/mode } \\
\text { of action }\end{array}$ & $\begin{array}{l}\text { Duration of } \\
\text { treatment }\end{array}$ & $\begin{array}{c}\text { Route of } \\
\text { administration }\end{array}$ & References \\
\hline $\begin{array}{l}\text { Anti-obesity and } \\
\text { insulin resistance }\end{array}$ & Celastrol & $\begin{array}{l}\text { C57BL/6 mice were } \\
\text { allowed to recover for } \\
2 \text { weeks postsurgery } \\
\text { before receiving } \\
\text { intraperitoneal vehicle or } \\
\text { celastrol }(100 \mu \mathrm{g} / \mathrm{kg}) \text { at } 6 \\
\text { pm each day }\end{array}$ & $\begin{array}{l}\downarrow T C, T G, L D L-C \text { and Apo B in } \\
\text { plasma, } \downarrow N A D P H \text { oxidase activity }\end{array}$ & 10 consecutive days & $\begin{array}{l}\text { Intraperitoneal } \\
\text { injection }\end{array}$ & $\begin{array}{l}\text { Kyriakou et al. } \\
(2018)\end{array}$ \\
\hline- & Celastrol & $\begin{array}{l}\text { Sprague-Dawley rats were } \\
\text { treated with celastrol } \\
(1.0 \mathrm{ml} / 100 \mathrm{~g}) \text { or } \\
\text { simvastatin }(1.0 \mathrm{ml} / 100 \mathrm{~g})\end{array}$ & $\begin{array}{l}\text { Tprotein phosphorylation of } \\
\text { insulin signalling cascades with } \\
\text { amplified expression of AMPK } \\
\text { protein, \attenuated NF-kB and } \\
\text { PKC } \theta \text { activation }\end{array}$ & 6 weeks & $\begin{array}{l}\text { Intragastrical } \\
\text { administration }\end{array}$ & $\begin{array}{l}\text { Wang et al. } \\
(2014)\end{array}$ \\
\hline Antiviral effect & Triptolide & $\begin{array}{l}\text { Male BALB/C mice were } \\
\text { intravenously (i.v.) treated } \\
\text { with a single dose of TP } \\
(1.2 \mathrm{mg} / \mathrm{kg})\end{array}$ & $\begin{array}{l}\downarrow T N F-\alpha, I L-1 \beta, I L-6 \\
\text { malondialdehyde (MDA) and } \\
\text { antioxidative superoxide } \\
\text { dismutase (SOD), } \uparrow \text { glutathione } \\
\text { (GSH) and glutathione } \\
\text { peroxidase (GPx) }\end{array}$ & $24 \mathrm{~h}$ & Intravenous injection & $\begin{array}{l}\text { Zhou et al. } \\
\text { (2014) }\end{array}$ \\
\hline Other effects & Celastrol & $\begin{array}{l}\text { Celastrol (0.5 and } \\
1.0 \mathrm{mg} / \mathrm{kg} \text {, i.v.) was } \\
\text { administered to } \\
\text { anaesthetized rats } 2 \mathrm{~h} \\
\text { before and } 30 \mathrm{~min} \text { after } \\
\text { LPS challenge } \\
(10 \mathrm{mg} / \mathrm{kg} \text {, i.v.) }\end{array}$ & $\begin{array}{l}\uparrow N \text { rf2 activation, } \downarrow \text { Nox } 2 / A T 1 \\
\text { receptor expression, } \\
\uparrow p h o s p h o r y l a t i o n ~ o f ~ E R K 1 / 2\end{array}$ & $8 \mathrm{~h}$ & Intravenous injection & $\begin{array}{l}\text { Wang et al. } \\
(2015)\end{array}$ \\
\hline
\end{tabular}

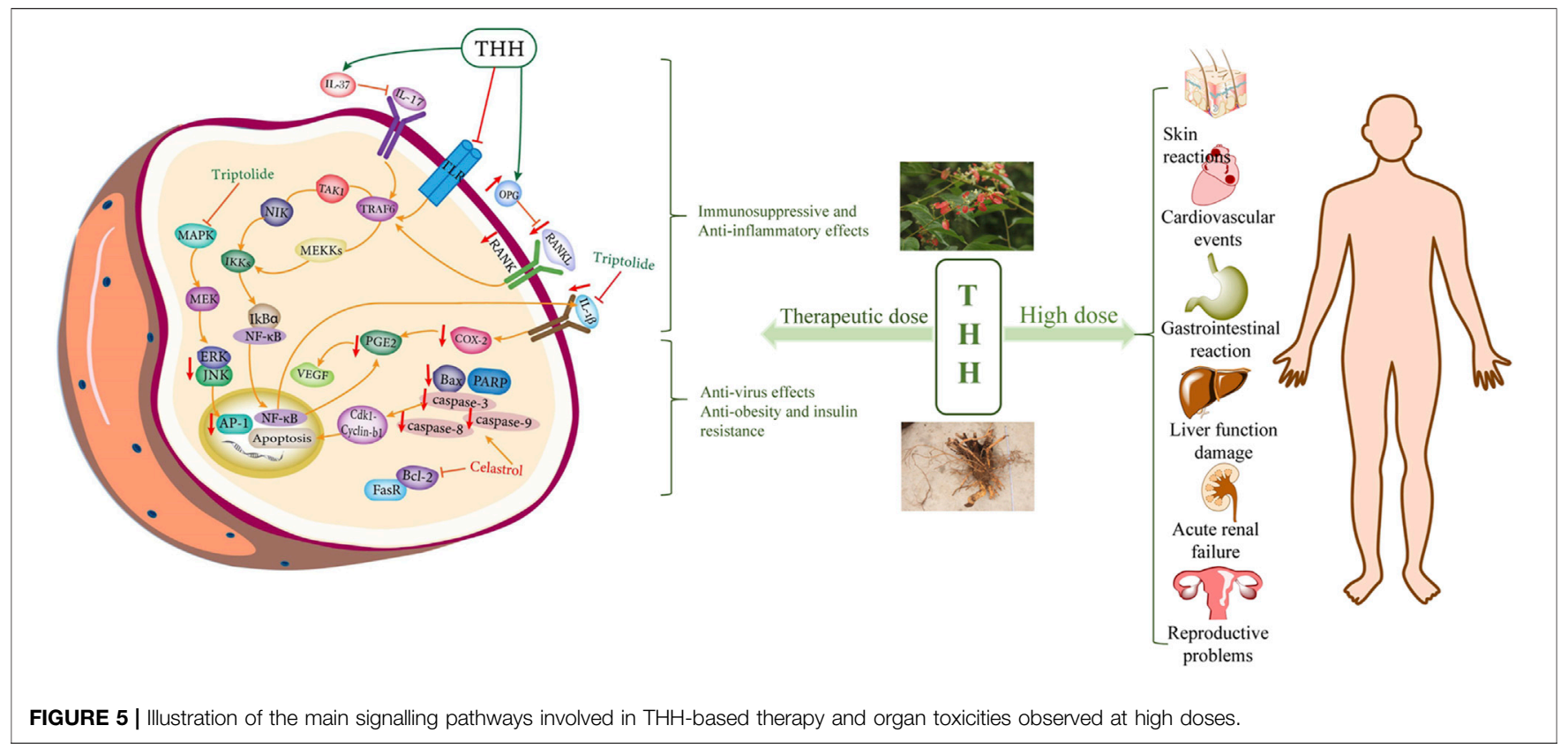

hepatic GSH-Px, CAT, and SOD activities (Yang et al., 2017). It also regulates the metabolism of sphingolipids and glycerophospholipids by affecting metabolites and key proteins such as sphingosine, PC, PKC, PAH, LPC, and PLC, which cause disturbances in $\mathrm{Ca}^{2+}$ channels and stimulate oxidative stress levels, leading to kidney damage (Xie et al., 2020). Therefore, reducing liver toxicity and nephrotoxicity through chemical modification is an important topic for triptolide to be applied.

Triptolide induced cytotoxicity in L02 cells, caused mitochondrial dysfunction and altered mitochondrial dynamics, mainly characterized by an imbalance in mitochondrial fusion and fission protein mitochondrial 
fragmentation. Mitochondrial fragmentation can lead to increasing autophagic flux by triptolide. Changes in mitochondrial dynamics were associated with increasing expression of the Drp1 fission protein. Despite no significant effect on L02 cells, triptolide doses of 12.5, 25 and $50 \mathrm{nM}$ were significantly toxic. Mdivi-1 is a potent mitochondrial fission inhibitor that reverses mitophagy by inhibiting mitochondrial fission and increasing mitophagy in vitro and in vivo (Hasnat et al., 2019). Treatment of mice with the PPARa agonist fenofibrate alleviated triptolide-induced liver injury, whereas the PPARa antagonist GW6471 increased hepatotoxicity and increased long-chain acylcarnitine through activation of the NOTCH-NRF2 pathway to protect against triptolide-induced liver damage ( $\mathrm{Hu}$ et al., 2019). The hepatotoxicity of triptolide is closely related to its dose, indicating that the liver is more sensitive to other drugs (CYP450 inhibitors) and their accumulation. Thus, celastrol, which is also a hepatotoxic component of $\mathrm{THH}$ and an inhibitor of CYP450, could aggravate triptolide-induced hepatotoxicity, which may explain why the combination of celastrol and triptolide causes more severe liver injury. In summary, celastrol and triptolide damaged primary rat hepatocytes by decreasing cell viability, enhancing cellular stress, decreasing MMP, increasing LDH and ROS levels, and inevitably damaging the cell membrane (Jin C. et al., 2015; Jin et al., 2019).

However, Arctiin exerts antioxidant effects mediated by the Nrf2/ARE pathway and alleviates triptolide-induced hepatotoxicity, and its molecular mechanism may be related to its antioxidative stress ability (Jin J. et al., 2015; Wei et al., 2019). A novel mechanism of triptolide-induced hepatotoxicity is mitochondrial fission associated mitophagy, and triptolideinduced hepatotoxicity can be targeted by mitochondrial fission and mitochondrial autophagy signalling pathways (Hasnat et al., 2019). Specifically, $18 \beta$ glycyrrhetinic acid (GA) is the main bioactive component of liquorice (Glycyrrhiza glabra L.), and low-dose GA (50 mg/kg) effectively reduces triptolideinduced hepatotoxicity in rats through its inflammatory, antioxidative, and antiapoptotic effects (Yang et al., 2017). GA reduced the accumulation of triptolide in $\mathrm{HK}-2$ cells, which were related to P-gp (Li Z. et al., 2017). Pretreatment with GL significantly accelerates the metabolic elimination of triptolide from the body mainly through induction of hepatic CYP3A activity (Tai et al., 2014). Thus, the combination of triptolide with other natural compounds may be an effective measure to control its toxicity and ensure its safety, there still need more further research to investigate its mechanism of combination.

\section{DISCUSSION AND CONCLUSION}

Traditional Chinese medicine (TCM) has unique therapeutic advantages in the treatment of a variety of complex diseases and major diseases, such as cholestasis, nonalcoholic fatty liver disease, liver fibrosis, and ischaemic stroke (Jiang et al., 2020a; Hu et al., 2020). The genus Tripterygium contains only 3 species, i.e. Tripterygium wilfordii Hook. f., Tripterygium hypoglaucum $(\mathrm{H}$. Lév.) Hutch. and Tripterygium regelii Sprague and Takeda. In the last 10 years, many studies have discussed the plants related to the genus Tripterygium. Among them, Tripterygium wilfordii Hook. $\mathrm{f}$., as one of the widely reported plants, has occupied almost all the focus of the review of the genus Tripterygium. Individual scholars have included the chemical constituents and pharmacological activities of $\mathrm{THH}$ in their studies on the genus Tripterygium ( $\mathrm{Lv}$ et al., 2019). In contrast, our study separately investigated the related active components and pharmacological effects of $\mathrm{THH}$, providing more selectivity for the extraction of components from the genus Tripterygium. In addition, we updated the recently published experimental studies and supplemented the pharmacokinetic studies of compounds in $\mathrm{THH}$, so as to provide some ideas for the development of new drugs.

In this review, we summarized the various bioactive components of $\mathrm{THH}$, such as sesquiterpenes, diterpenes, triterpenoids, flavonoids, and lignans. In this review, we introduced the structural grouping of 120 secondary metabolites of $\mathrm{THH}$ and described the activity data obtained from $\mathrm{THH}$ research in the past 2 decades. The compounds isolated from TwHF, including triptolide and tripdiolide, induce male infertility (Wang et al., 2014). Although the prospects of male antifertility drugs have been explored, further safety evaluation results of this drug are needed. Therefore, THH is likely to be a genotoxic agent. Chinese investigators are cautious and suggest that patients should avoid reproduction for 6 months after THH therapy (Liang et al., 2006). In addition, we emphasized the pharmacological effects of triptolide, celastrol and other important bioactive components, and great progress has been made in the identification of the mechanisms associated with these components, such as anti-inflammatory, immunosuppressive, and anti-tumour effects. At $50 \mathrm{nM}$, triptolide could completely block the LPS-induced PGE2 release. Further, triptolide at 50 or $100 \mathrm{nM}$ in primary microglial cells was not toxic (Jiao et al., 2008). In addition, the animals pretreated with triptolide $(100 \mathrm{mg} / \mathrm{kg})$ show significant attenuation of LPS-induced proinflammatory cytokine release in serum, including TNF-a, IL-6, and IL-12, but not IL-1 $\beta$ (Huang et al., 2019). Triptolide could suppress CD80 and CD86 expressions on IFN- $\gamma(500 \mathrm{kU} /$ $\mathrm{L}$ ) and LPS ( $1 \mathrm{mg} / \mathrm{L}$ )-activated THP-1 cells at $2.5-0.625 \mu \mathrm{g} / \mathrm{L}$ (Liu et al., 2005). Celastrol caused a dose- and time-dependent growth inhibition of A549 cells with an $\mathrm{IC}_{50}$ of $2.12 \mu \mathrm{M}$ at $48 \mathrm{~h}$ treatment (Mou et al., 2011). Celastrol at the optimum concentration of $30 \mathrm{nM}$ was able to protect the cells from mitochondrial dysfunction and insulin resistance (Abu Bakar et al., 2017).

At present, the studies in vitro and in vivo are relatively separate from each other. There is a lack of relevance between experiments in vitro and in vivo especially in the aspect of dosage. In future studies, more attention should be paid to research to understand whether the concentration used in vitro can achieve the same efficacy in vivo. In conclusion, some data suggest that triptolide may possess anti-angiogenic effect in RA both in vivo and in vitro assay systems by downregulating the angiogenic activators and inhibiting the activation of mitogen-activated protein kinase downstream signal pathway (Kong et al., 2013). Triptonide effectively inhibited pancreatic cancer cell-formed capillary-like structures in vitro and blood vessels in vivo 
through suppressing pancreatic cancer cell migration, invasion, and VM via inhibiting expression of tumour VM master gene VEcadherin and pro-migratory gene chemokine $\mathrm{C}-\mathrm{X}-\mathrm{C}$ motif ligand 2 (CXCL2), mainly via reduction of gene promoter activity (Han et al., 2018). This is particularly crucial for the exploration of antitumour effect. However, this promising effect seems less to be displayed in vivo. It is to be due to the complex system of the body. Therefore, from the perspective of animals or even humans, we should construct a systematic experiment synchronously carried out the experiment in vitro and in vivo. Furthermore, the dosage for these studies should confirm the stability of the effect. In addition, researchers have discovered new pharmacological effects of these compounds, including alleviation of $\mathrm{AD}$ and insulin resistance as well as anti-obesity, and cardioprotective effects. However, these herbs also have potential multiorgan toxicity that has not been addressed for many years (Wang L. et al., 2018). Pharmacodynamic and toxicological studies of $\mathrm{THH}$ are closely related to pharmacokinetics and tissue distribution. Due to the lack of studies on human pharmacokinetics, it is unclear whether the pharmacological effects obtained at the concentrations of compounds used in vitro can achieve the same efficacy in humans. Therefore, various toxic reactions might occur in clinical application. Many studies have reported the metabolic processing of toxic active compounds in vitro and in vivo, aiming to reduce drug toxicity and improve the safety of these agents from a metabolic point of view or using different methods.

Alternatively, many low toxicity active analogues have been developed by drug synthesis researchers from natural active products of the genus Tripterygium (Shan et al., 2017; Ning et al., 2018). The Chinese pharmacopoeia indicates that THH patent medicine (Kunming Shanhaitang tablet) is made from extracts of THH dried roots, and this is a legally licenced drug in China. Kunming Shanhaitang tablet is commonly used to treat RA. Inhibition of IL-2 production by human peripheral blood lymphocytes through nuclear inhibition of transcriptional activation of NF- $\mathrm{B}$, prevention of $\mathrm{T}$ cell proliferation, induction of apoptotic death of $\mathrm{T}$ lymphocytes, reduction of PGE2 production in human monocytes and rheumatoid arthritis synovial fibroblasts, suppression of complement C3 and the expression of CD40 and B7 in activated human proximal tubular epithelial cells by triptolide indicates a wide range therapeutic target cells of this Chinese herb. Dex is a wellknown classical glucocorticoid with potent anti-inflammatory and immunosuppressive effects when gave in pharmacological doses. Though the effect of triptolide is not so strong as Dex in the clinical managements, it shares the properties of Dex such as anti-inflammation and immunosuppression. Here, we demonstrated that DC is a target of triptolide. Due to DC has the unique property to activate native $\mathrm{T}$ cells and is required for the induction of a primary response, the suppression of DC function may very efficiently control the specific immune response. One of the mechanisms by which triptolide can suppress the immune response in humans is by inhibiting differentiation, terminal maturation and function of DC. In addition, triptolide abrogates the capacity of mature DCs to secrete IL-12 and also promotes DC apoptosis. These effects result in inhibition of alloreactive $\mathrm{T}$ cell activation. Suppression of DC may contribute to the actions of triptolide in the treatment of immune-related diseases and for the prevention of allograft rejection. Adjuvant treatment of facial corticosteroid addiction dermatitis with Kunming Shanhaitang tablet effectively improved symptoms and manifestations within 2 months and was more beneficial than topical drugs alone in significantly improving symptoms in the first 2 weeks. In addition, the effect was comparable to that of antihistamine combined with topical drugs or topical drugs alone (Xue and $\mathrm{Wu}, 2008)$. The injection of $\mathrm{THH}$ demonstrates a significant inhibitory effect on the production of haemolysin antibodies in mice, and the effect is more obvious with a long period of dosing (Li X, 2006). Tripterygium agents (TAs) extracted from TwHF are a complementary therapy used to treat eczema based on previous experience. However, TA has significant side effects in the treatment of specific eczema, but seems to be effective only in combination with some therapies. Thus, researchers believe that TA cannot be used clinically for eczema in general (Liu et al., 2019). Less toxic preparation of THH could potentially be used as an alternative. In previous separation and extraction experiments, most of the chemical active ingredients of $\mathrm{THH}$ were extracted with $95 \%$ ethanol, but it was found that column chromatography was replaced by sodium carbonate extraction for removing the acidic compounds and enriching epoxyditerpenoids and alkaloids in the extract. The therapeutic index $\left(\mathrm{IC}_{50} / \mathrm{EC}_{50}\right)$ on murine macrophage Raw 264.7 cells and rat mesangial HBZY-1 cells of the extract prepared by sodium carbonate extraction was significantly higher than that of Tripterygium glycosides $(0.8$ and 5.2 vs. 0.3 and 2.6), while its cytotoxicity on human liver HL7702 cells was significantly lower $(14.5 \pm 1.4$ vs. $6.8 \pm 0.9$,). Therefore, Tripterygium extract prepared by sodium carbonate extraction may represent a potentially optimal source of medicine with good therapeutic index (Fang et al., 2012). Therefore, many studies have shown that $\mathrm{THH}$ is a potential source of various drugs. Here, we consulted the literature and summarized the useful information and evidence. From the current research, it can be seen that a variety of active components of THH show significant efficacy and great potential in many major diseases. Toxicity is the main factor limiting $\mathrm{THH}$ in drug development. To date, the research on the mechanism of toxicity caused by $\mathrm{THH}$ is not sufficient. A full understanding of the mechanism of toxicity induced by $\mathrm{THH}$ is the premise to effectively reduce the toxicity of $\mathrm{THH}$, and it is also the key to the development of $\mathrm{THH}$ efficacy. So do other plants of the genus Tripterygium. Through continuous in-depth studies of THH and TwHF, our understanding of their structure, pharmacology, toxicology and other aspects will be further advanced, which will provide a solid theoretical basis for their clinical application. In the future, if we focus on preserving the active ingredients and minimizing the toxic components of the preparations, these agents will certainly have broader prospects in various fields.

In conclusion, $\mathrm{THH}$ has abundant chemically active components, and some representative components (triptolide, celastrol, etc.,) have been demonstrated to have significant antiinflammatory, immunosuppressive and anti-tumour effects. 
Meanwhile, the toxicity of THH cannot be underestimated. How to effectively control the toxicity of $\mathrm{THH}$ and obtain the maximum therapeutic effect is still a problem to be solved. The combination of traditional theory and modern advanced technology will be an important goal for the efficacy and safety of traditional Chinese medicine.

\section{AUTHOR CONTRIBUTIONS}

$\mathrm{JZ}$ is the major contributor to this manuscript. JZ conducted the analytical part, wrote the first version of the manuscript, FZ, XX, and ZW finalized the manuscript. XX, YJ, and WZ, downloaded the reference and processed the graph and the table in the manuscript. SW, QH, collected the data. XM and $\mathrm{XZ}$ (corresponding author) conceived and coordinated the study, and critically evaluated the data. All authors read and approved the final manuscript.

\section{REFERENCES}

Abdin, A. A., and Hasby, E. A. (2014). Modulatory Effect of Celastrol on Th1/Th2 Cytokines Profile, TLR2 and CD3+ T-Lymphocyte Expression in a RelapsingRemitting Model of Multiple Sclerosis in Rats. Eur. J. Pharmacol. 742, 102-112. doi:10.1016/j.ejphar.2014.09.001

Abu Bakar, M. H., Cheng, K.-K., Sarmidi, M. R., Yaakob, H., and Huri, H. Z. (2015). Celastrol Protects against Antimycin A-Induced Insulin Resistance in Human Skeletal Muscle Cells. Molecules 20, 8242-8269. doi:10.3390/ molecules20058242

Abu Bakar, M. H., Sarmidi, M. R., Tan, J. S., and Mohamad Rosdi, M. N. (2017). Celastrol Attenuates Mitochondrial Dysfunction and Inflammation in Palmitate-Mediated Insulin Resistance in C3A Hepatocytes. Eur. J. Pharmacol. 799, 73-83. doi:10.1016/j.ejphar.2017.01.043

Abu Bakar, M. H., and Tan, J. S. (2017). Improvement of Mitochondrial Function by Celastrol in Palmitate-Treated C2C12 Myotubes via Activation of PI3K-Akt Signalling Pathway. Biomed. Pharmacother. 93, 903-912. doi:10.1016/ j.biopha.2017.07.021

Bakar, M. H. A., Sarmidi, M. R., Kai, C. K., Huri, H. Z., and Yaakob, H. (2014). Amelioration of Mitochondrial Dysfunction-Induced Insulin Resistance in Differentiated 3T3-L1 Adipocytes via Inhibition of NF-Kb Pathways. Int. J. Mol. Sci. 15, 22227-22257. doi:10.3390/ijms151222227

Baker, J. T., Borris, R. P., Carté, B., Cordell, G. A., Soejarto, D. D., Cragg, G. M., et al. (1995). Natural Product Drug Discovery and Development: New Perspectives on International Collaboration. J. Nat. Prod. 58, 1325-1357. doi:10.1021/ np50123a003

Booij, T. H., Leonhard, W. N., Bange, H., Yan, K., Fokkelman, M., Plugge, A. J., et al. (2020). In Vitro 3D Phenotypic Drug Screen Identifies Celastrol as an Effective In Vivo Inhibitor of Polycystic Kidney Disease. J. Mol. Cel Biol. 12, 644-653. doi:10.1093/jmcb/mjz029

Brinker, A. M., Ma, J., Lipsky, P. E., and Raskin, I. (2007). Medicinal Chemistry and Pharmacology of Genus Tripterygium (Celastraceae). Phytochemistry 68, 732-766. doi:10.1016/j.phytochem.2006.11.029

Cascão, R., Vidal, B., Raquel, H., Neves-Costa, A., Figueiredo, N., Gupta, V., et al. (2012). Effective Treatment of Rat Adjuvant-Induced Arthritis by Celastrol. Autoimmun. Rev. 11, 856-862. doi:10.1016/j.autrev.2012.02.022

Chan, T. Y. K. (2012). Aconitum Alkaloid Content and the High Toxicity of Aconite Tincture. Forensic Sci. Int. 222, 1-3. doi:10.1016/j.forsciint.2012.02.026

Chan, T. Y. K. (2011). Causes and Prevention of Herb-Induced Aconite Poisonings in Asia. Hum. Exp. Toxicol. 30, 2023-2026. doi:10.1177/0960327111407224

Chang, W., He, W., Li, P.-P., Song, S.-S., Yuan, P.-F., Lu, J.-T., et al. (2016). Protective Effects of Celastrol on Diethylnitrosamine-Induced Hepatocellular Carcinoma in Rats and its Mechanisms. Eur. J. Pharmacol. 784, 173-180. doi:10.1016/j.ejphar.2016.04.045

\section{FUNDING}

This work was supported by National Natural Science Foundation of China $(81874365,81703725)$, Sichuan Science and Technology Program (2019YJ0492), Beijing Medical and Health Foundation (YWJKJJHKYJJ-B20645FN), Chengdu University of TCM Found Grant (QNXZ2018025), National Major New Drug Creation Major Science and Technology Projects (2017ZX09101002-002-004), Natural Science Foundation of Chongqing (cstc2017jcyjAX0001, cstc2018jcyjAX0142).

\section{ACKNOWLEDGMENTS}

The authors would like to thank the reviewers and also the authors of all references. The reviewer's advice really makes the great improvement of this paper.

Chen, G., Zhang, X., Zhao, M., Wang, Y., Cheng, X., Wang, D., et al. (2011) Celastrol Targets Mitochondrial Respiratory Chain Complex I to Induce Reactive Oxygen Species-dependent Cytotoxicity in Tumour Cells. BMC Cancer 11, 170. doi:10.1186/1471-2407-11-170

Chen, S.-R., Dai, Y., Zhao, J., Lin, L., Wang, Y., and Wang, Y. (2018a). A Mechanistic Overview of Triptolide and Celastrol, Natural Products from Tripterygium Wilfordii Hook F. Front. Pharmacol. 9, 104. doi:10.3389/ fphar.2018.00104

Chen, X.-L., Liu, F., Xiao, X.-R., Yang, X.-W., and Li, F. (2018b). Antiinflammatory Abietanes Diterpenoids Isolated from Tripterygium Hypoglaucum. Phytochemistry 156, 167-175. doi:10.1016/ j.phytochem.2018.10.001

Chen, X., Murakami, T., Oppenheim, J. J., and Howard, O. M. Z. (2005). Triptolide, a Constituent of Immunosuppressive Chinese Herbal Medicine, Is a Potent Suppressor of Dendritic-Cell Maturation and Trafficking. Blood 106, 2409-2416. doi:10.1182/blood-2005-03-0854

Cheng, H.-Y., Lin, C.-C., and Lin, T.-C. (2002). Antiherpes Simplex Virus Type 2 Activity of Casuarinin from the Bark of Terminalia Arjuna Linn. Antivir. Res 55, 447-455. doi:10.1016/s0166-3542(02)00077-3

Collins, R. R. J., Patel, K., Putnam, W. C., Kapur, P., and Rakheja, D. (2017). Oncometabolites: A New Paradigm for Oncology, Metabolism, and the Clinical Laboratory. Clin. Chem. 63, 1812-1820. doi:10.1373/ clinchem.2016.267666

Costa, C., Incio, J., and Soares, R. (2007). Angiogenesis and Chronic Inflammation: Cause or Consequence? Angiogenesis 10, 149-166. doi:10.1007/s10456-0079074-0

Ding, L., and Zhang, Z. (1991). Studies on Chemical Constituents of Tripterygium Hypoglaucum Stems II. Nanjing J. China Pharm. Univ., 25-26.

Duan, H., Kawazoe, K., Bando, M., Kido, M., and Takaishi, Y. (1997). Di- and Triterpenoids from Tripterygium Hypoglaucum. Phytochemistry 46, 103-110. doi:10.1016/s0031-9422(97)00288-4

Duan, H., Takaishi, Y., Imakura, Y., Jia, Y., Li, D., Cosentino, L. M., et al. (2000). Sesquiterpene Alkaloids from Tripterygium Hypoglaucum and Tripterygium Wilfordii: a New Class of Potent Anti-HIV Agents. J. Nat. Prod. 63, 357-361. doi:10.1021/np990281s

Duan, H., and Takaishi, Y. (1999). Sesquiterpene Evoninate Alkaloids from Tripterygium Hypoglaucum. Phytochemistry 52, 1735-1738. doi:10.1016/ s0031-9422(99)00179-X

Duan, H., and Takaishi, Y. (1998). Structures of Sesquiterpene Polyol Alkaloids from Tripterygium Hypoglaucum. Phytochemistry 49, 357. doi:10.1016/s00319422(98)00439-7

Dudics, S., Langan, D., Meka, R. R., Venkatesha, S. H., Berman, B. M., Che, C.-T., et al. (2018). Natural Products for the Treatment of Autoimmune Arthritis: Their Mechanisms of Action, Targeted Delivery, and Interplay with the Host Microbiome. Int. J. Mol. Sci. 19, 2508. doi:10.3390/ijms19092508 
El Hajj, H., Dassouki, Z., Berthier, C., Raffoux, E., Ades, L., Legrand, O., et al. (2015). Retinoic Acid and Arsenic Trioxide Trigger Degradation of Mutated NPM1, Resulting in Apoptosis of AML Cells. Blood 125, 3447-3454. doi:10.1182/blood-2014-11-612416

Fan, D., Guo, Q., Shen, J., Zheng, K., Lu, C., Zhang, G., et al. (2018). The Effect of Triptolide in Rheumatoid Arthritis: From Basic Research towards Clinical Translation. Int. J. Mol. Sci. 19, 376. doi:10.3390/ijms19020376

Fan, D., He, X., Bian, Y., Guo, Q., Zheng, K., Zhao, Y., et al. (2016). Triptolide Modulates TREM-1 Signal Pathway to Inhibit the Inflammatory Response in Rheumatoid Arthritis. Int. J. Mol. Sci. 17, 498. doi:10.3390/ijms17040498

Fan, X.-X., Li, N., Wu, J.-L., Zhou, Y.-L., He, J.-X., Liu, L., et al. (2014). Celastrol Induces Apoptosis in Gefitinib-Resistant Non-small Cell Lung Cancer Cells via Caspases-dependent Pathways and Hsp90 Client Protein Degradation. Molecules 19, 3508-3522. doi:10.3390/molecules 19033508

Fang, W., Peng, F., Yi, T., Zhang, C., Wan, C., Xu, H., et al. (2012). Biological Activity and Safety of Tripterygium Extract Prepared by Sodium Carbonate Extraction. Molecules 17, 11113-11123. doi:10.3390/molecules170911113

Feng, X., Guan, D., Auen, T., Choi, J. W., Salazar Hernández, M. A., Lee, J., et al. (2019a). IL1R1 Is Required for Celastrol's Leptin-Sensitization and Antiobesity Effects. Nat. Med. 25, 575-582. doi:10.1038/s41591-019-0358-x

Feng, X., Lv, C., Wang, F., Gan, K., Zhang, M., and Tan, W. (2013). Modulatory Effect of 1,25-dihydroxyvitamin D 3 on IL1 $\beta$-induced RANKL, OPG, TNF $\alpha$, and IL-6 Expression in Human Rheumatoid Synoviocyte MH7A. Clin. Dev. Immunol. 2013, 160123. doi:10.1155/2013/160123

Feng, Z., Zhou, C., Dong, S., Liu, Z., Liu, T., Zhou, L., et al. (2019b). Catalpol and Panax Notoginseng Saponins Synergistically Alleviate Triptolide-Induced Hepatotoxicity through Nrf2/ARE Pathway. Toxicol. Vitro 56, 141-149. doi:10.1016/j.tiv.2019.01.016

Fu, Q., Huang, X., Shu, B., Xue, M., Zhang, P., Wang, T., et al. (2011). Inhibition of Mitochondrial Respiratory Chain Is Involved in Triptolide-Induced Liver Injury. Fitoterapia 82, 1241-1248. doi:10.1016/j.fitote.2011.08.019

Fujita, R., Duan, H., and Takaishi, Y. (2000). Terpenoids from Tripterigyum Hypoglaucum. Phytochemistry 53, 715-722. doi:10.1016/s0031-9422(99) 00557-9

Gan, K., Xu, L., Feng, X., Zhang, Q., Wang, F., Zhang, M., et al. (2015). Celastrol Attenuates Bone Erosion in Collagen-Induced Arthritis Mice and Inhibits Osteoclast Differentiation and Function in RANKL-Induced RAW264.7. Int. Immunopharmacol. 24, 239-246. doi:10.1016/j.intimp.2014.12.012

Gong, Y., Xue, B., Jiao, J., Jing, L., and Wang, X. (2008). Triptolide Inhibits COX-2 Expression and PGE2 Release by Suppressing the Activity of NF-kappaB and JNK in LPS-Treated Microglia. J. Neurochem. 107, 779-788. doi:10.1111/j.14714159.2008.05653.x

Guo, Y., Wang, Y., Shi, X., Qin, W., Zhang, X., Xu, J., et al. (2018). A Metabolomics Study on the Immunosuppressive Effect of Tripterygium Hypoglaucum (Levl.) Hutch in Mice: The Discovery of Pathway Differences in Serum Metabolites. Clin. Chim. Acta 483, 94-103. doi:10.1016/j.cca.2018.04.004

Han, H., Du, L., Cao, Z., Zhang, B., and Zhou, Q. (2018). Triptonide Potently Suppresses Pancreatic Cancer Cell-Mediated Vasculogenic Mimicry by Inhibiting Expression of VE-Cadherin and Chemokine Ligand 2 Genes. Eur. J. Pharmacol. 818, 593-603. doi:10.1016/j.ejphar.2017.11.019

Harmey, J. H., Bucana, C. D., Lu, W., Byrne, A. M., McDonnell, S., Lynch, C., et al. (2002). Lipopolysaccharide-induced Metastatic Growth Is Associated with Increased Angiogenesis, Vascular Permeability and Tumour Cell Invasion. Int. J. Cancer 101, 415-422. doi:10.1002/ijc.10632

Hasnat, M., Yuan, Z., Naveed, M., Khan, A., Raza, F., Xu, D., et al. (2019). Drp1associated Mitochondrial Dysfunction and Mitochondrial Autophagy: a Novel Mechanism in Triptolide-Induced Hepatotoxicity. Cell Biol. Toxicol. 35, 267-280. doi:10.1007/s10565-018-9447-8

Hernández-Aguilera, A., Rull, A., Rodríguez-Gallego, E., Riera-Borrull, M., Luciano-Mateo, F., Camps, J., et al. (2013). Mitochondrial Dysfunction: a Basic Mechanism in Inflammation-Related Non-communicable Diseases and Therapeutic Opportunities. Mediators Inflamm. 2013, 135698. doi:10.1155/ 2013/135698

Hu, D.-D., Zhao, Q., Cheng, Y., Xiao, X.-R., Huang, J.-F., Qu, Y., et al. (2019). The Protective Roles of PPARa Activation in Triptolide-Induced Liver Injury. Toxicol. Sci. 171, 1-12. doi:10.1093/toxsci/kfz146

Hu, Q., Wei, S., Wen, J., Zhang, W., Jiang, Y., Qu, C., et al. (2020). Network Pharmacology Reveals the Multiple Mechanisms of Xiaochaihu Decoction in the Treatment of Non-alcoholic Fatty Liver Disease. BioData Min 13, 11. doi:10.1186/s13040-020-00224-9

Huang, Y., Zhu, N., Chen, T., Chen, W., Kong, J., Zheng, W., et al. (2019). Triptolide Suppressed the Microglia Activation to Improve Spinal Cord Injury through miR-96/ikk $\beta /$ nf-Kb Pathway. Spine (Phila. Pa. 1976) 44, E707-E714. doi:10.1097/BRS.0000000000002989

Jang, S. Y., Jang, S.-W., and Ko, J. (2011). Celastrol Inhibits the Growth of Estrogen Positive Human Breast Cancer Cells through Modulation of Estrogen Receptor a. Cancer Lett. 300, 57-65. doi:10.1016/j.canlet.2010.09.006

Jiang, X., Huang, X., Ao, L., Liu, W., Han, F., Cao, J., et al. (2014). Total Alkaloids of Tripterygium Hypoglaucum (levl.) Hutch Inhibits Tumour Growth Both In Vitro and In Vivo. J. Ethnopharmacol. 151, 292-298. doi:10.1016/ j.jep.2013.10.045

Jiang, Y., Wen, J., Zhang, W., Ma, Z., Zhang, C., Wang, J., et al. (2020a). Metabolomics Coupled with Integrative Pharmacology Reveals the Therapeutic Effect of L-Borneolum against Cerebral Ischaemia in Rats. J. Pharm. Pharmacol. 72, 1256-1268. doi:10.1111/jphp.13294

Jiang, Y., Zhong, M., Long, F., and Yang, R. (2020b). Deciphering the Active Ingredients and Molecular Mechanisms of Tripterygium Hypoglaucum (Levl.) Hutch against Rheumatoid Arthritis Based on Network Pharmacology. Evid. Based. Complement. Alternat. Med. 2020, 2361865. doi:10.1155/2020/2361865

Jiao, J., Xue, B., Zhang, L., Gong, Y., Li, K., Wang, H., et al. (2008). Triptolide Inhibits Amyloid-Beta1-42-Induced TNF-Alpha and IL-1beta Production in Cultured Rat Microglia. J. Neuroimmunol. 205, 32-36. doi:10.1016/ j.jneuroim.2008.08.006

Jin, C., He, X., Zhang, F., He, L., Chen, J., Wang, L., et al. (2015a). Inhibitory Mechanisms of Celastrol on Human Liver Cytochrome P450 1A2, 2C19, 2D6, 2E1 and 3A4. Xenobiotica 45, 571-577. doi:10.3109/ 00498254.2014 .1003113

Jin, C., Wu, Z., Wang, L., Kanai, Y., and He, X. (2019). CYP450s-Activity Relations of Celastrol to Interact with Triptolide Reveal the Reasons of Hepatotoxicity of Tripterygium Wilfordii. Molecules 24, 2162. doi:10.3390/molecules24112162

Jin, J., Sun, X., Zhao, Z., Wang, W., Qiu, Y., Fu, X., et al. (2015b). Activation of the Farnesoid X Receptor Attenuates Triptolide-Induced Liver Toxicity. Phytomedicine 22, 894-901. doi:10.1016/j.phymed.2015.06.007

Joshi, V., Venkatesha, S. H., Ramakrishnan, C., Nanjaraj Urs, A. N., Hiremath, V., Moudgil, K. D., et al. (2016). Celastrol Modulates Inflammation through Inhibition of the Catalytic Activity of Mediators of Arachidonic Acid Pathway: Secretory Phospholipase A(2) Group IIA, 5-lipoxygenase and Cyclooxygenase-2. Pharmacol. Res. 113, 265-275. doi:10.1016/ j.phrs.2016.08.035

Jung, H. W., Chung, Y. S., Kim, Y. S., and Park, Y.-K. (2007). Celastrol Inhibits Production of Nitric Oxide and Proinflammatory Cytokines through MAPK Signal Transduction and NF-kappaB in LPS-Stimulated BV-2 Microglial Cells. Exp. Mol. Med. 39, 715-721. doi:10.1038/emm.2007.78

Kchour, G., Tarhini, M., Kooshyar, M.-M., El Hajj, H., Wattel, E., Mahmoudi, M., et al. (2009). Phase 2 Study of the Efficacy and Safety of the Combination of Arsenic Trioxide, Interferon Alpha, and Zidovudine in Newly Diagnosed Chronic Adult T-Cell Leukemia/lymphoma (ATL). Blood 113, 6528-6532. doi:10.1182/blood-2009-03-211821

Khairul, I., Wang, Q. Q., Jiang, Y. H., Wang, C., and Naranmandura, H. (2017). Metabolism, Toxicity and Anticancer Activities of Arsenic Compounds. Oncotarget 8, 23905-23926. doi:10.18632/oncotarget.14733

Kim, D. H., Shin, E. K., Kim, Y. H., Lee, B. W., Jun, J.-G., Park, J. H. Y., et al. (2009). Suppression of Inflammatory Responses by Celastrol, a Quinone Methide Triterpenoid Isolated from Celastrus Regelii. Eur. J. Clin. Invest. 39, 819-827. doi:10.1111/j.1365-2362.2009.02186.x

Kim, S. T., Kim, S. Y., Lee, J., Kim, K., Park, S. H., Park, Y. S., et al. (2018). Triptolide as a Novel Agent in Pancreatic Cancer: the Validation Using Patient Derived Pancreatic Tumour Cell Line. BMC Cancer 18, 1103. doi:10.1186/s12885-0184995-0

Kim, Y.-H., Lee, S.-H., Lee, J.-Y., Choi, S.-W., Park, J.-W., and Kwon, T. K. (2004). Triptolide Inhibits Murine-Inducible Nitric Oxide Synthase Expression by Down-Regulating Lipopolysaccharide-Induced Activity of Nuclear FactorKappa B and C-Jun NH2-terminal Kinase. Eur. J. Pharmacol. 494, 1-9. doi:10.1016/j.ejphar.2004.04.040

Kong, L.-L., Zhuang, X.-M., Yang, H.-Y., Yuan, M., Xu, L., and Li, H. (2015). Inhibition of P-Glycoprotein Gene Expression and Function Enhances 
Triptolide-Induced Hepatotoxicity in Mice. Sci. Rep. 5, 11747. doi:10.1038/ srep11747

Kong, X., Zhang, Y., Liu, C., Guo, W., Li, X., Su, X., et al. (2013). Anti-angiogenic Effect of Triptolide in Rheumatoid Arthritis by Targeting Angiogenic cascade. PLoS One 8, e77513. doi:10.1371/journal.pone.0077513

Krakauer, T., Chen, X., Howard, O. M. Z., and Young, H. A. (2005). Triptolide Attenuates Endotoxin- and Staphylococcal Exotoxin-Induced T-Cell Proliferation and Production of Cytokines and Chemokines. Immunopharmacol. Immunotoxicol. 27, 53-66. doi:10.1081/iph-51294

Kupchan, S. M., Court, W. A., Dailey, R. G. J., Gilmore, C. J., and Bryan, R. F. (1972). Triptolide and Tripdiolide, Novel Antileukemic Diterpenoid Triepoxides from Tripterygium Wilfordii. J. Am. Chem. Soc. 94, 7194-7195. doi:10.1021/ja00775a078

Kyriakou, E., Schmidt, S., Dodd, G. T., Pfuhlmann, K., Simonds, S. E., Lenhart, D., et al. (2018). Celastrol Promotes Weight Loss in Diet-Induced Obesity by Inhibiting the Protein Tyrosine Phosphatases PTP1B and TCPTP in the Hypothalamus. J. Med. Chem. 61, 11144-11157. doi:10.1021/ acs.jmedchem.8b01224

Lee, H.-W., Jang, K. S. Bin., Choi, H. J., Jo, A., Cheong, J.-H., and Chun, K.-H. (2014). Celastrol Inhibits Gastric Cancer Growth by Induction of Apoptosis and Autophagy. BMB Rep. 47, 697-702. doi:10.5483/bmbrep.2014.47.12.069

Lee, J.-H., Koo, T. H., Yoon, H., Jung, H. S., Jin, H. Z., Lee, K., et al. (2006). Inhibition of NF-Kappa B Activation through Targeting I Kappa B Kinase by Celastrol, a Quinone Methide Triterpenoid. Biochem. Pharmacol. 72, 1311-1321. doi:10.1016/j.bcp.2006.08.014

Lee, J.-H., Won, Y.-S., Park, K.-H., Lee, M.-K., Tachibana, H., Yamada, K., et al. (2012). Celastrol Inhibits Growth and Induces Apoptotic Cell Death in Melanoma Cells via the Activation ROS-dependent Mitochondrial Pathway and the Suppression of PI3K/AKT Signalling. Apoptosis 17, 1275-1286. doi:10.1007/s10495-012-0767-5

Lee, J. Y., Lee, B. H., Kim, N. D., and Lee, J. Y. (2015). Celastrol Blocks Binding of Lipopolysaccharides to a Toll-like Receptor4/myeloid Differentiation Factor2 Complex in a Thiol-dependent Manner. J. Ethnopharmacol. 172, 254-260. doi:10.1016/j.jep.2015.06.028

Li, C., Li, Z., Zhang, T., Wei, P., Li, N., Zhang, W., et al. (2019). (1)H NMR-Based Metabolomics Reveals the Antitumour Mechanisms of Triptolide in BALB/c Mice Bearing CT26 Tumours. Front. Pharmacol. 10, 1175. doi:10.3389/fphar.2019.01175

Li, G., Liu, D., Zhang, Y., Qian, Y., Zhang, H., Guo, S., et al. (2013a). Celastrol Inhibits Lipopolysaccharide-Stimulated Rheumatoid Fibroblast-like Synoviocyte Invasion through Suppression of TLR4/NF-Kb-Mediated Matrix Metalloproteinase-9 Expression. PLoS One 8, e68905. doi:10.1371/ journal.pone. 0068905

Li, G., Ren, J., Wang, G., Gu, G., Hu, D., Ren, H., et al. (2014a). T2 Enhances In Situ Level of Foxp3+ Regulatory Cells and Modulates Inflammatory Cytokines in Crohn's Disease. Int. Immunopharmacol. 18, 244-248. doi:10.1016/ j.intimp.2013.12.014

Li, H., Zhang, Y.-Y., Tan, H.-W., Jia, Y.-F., and Li, D. (2008). Therapeutic Effect of Tripterine on Adjuvant Arthritis in Rats. J. Ethnopharmacol. 118, 479-484. doi:10.1016/j.jep.2008.05.028

Li, J., Jin, J., Li, M., Guan, C., Wang, W., Zhu, S., et al. (2012a). Role of Nrf2 in protection against Triptolide-Induced Toxicity in Rat Kidney Cells. Toxicol. Lett. 213, 194-202. doi:10.1016/j.toxlet.2012.07.008

Li, J., Shen, F., Guan, C., Wang, W., Sun, X., Fu, X., et al. (2014b). Activation of Nrf2 Protects against Triptolide-Induced Hepatotoxicity. PLoS One 9, e100685. doi:10.1371/journal.pone.0100685

Li, M., Liu, X., He, Y., Zheng, Q., Wang, M., Wu, Y., et al. (2017a). Celastrol Attenuates Angiotensin II Mediated Human Umbilical Vein Endothelial Cells Damage through Activation of Nrf2/ERK1/2/Nox2 Signal Pathway. Eur. J. Pharmacol. 797, 124-133. doi:10.1016/j.jphar.2017.01.027

Li, P.-P., He, W., Yuan, P.-F., Song, S.-S., Lu, J.-T., and Wei, W. (2015a). Celastrol Induces Mitochondria-Mediated Apoptosis in Hepatocellular Carcinoma Bel7402 Cells. Am. J. Chin. Med. 43, 137-148. doi:10.1142/S0192415X15500093

Li, X.-J., Jiang, Z.-Z., and Zhang, L. (2014c). Triptolide: Progress on Research in Pharmacodynamics and Toxicology. J. Ethnopharmacol. 155, 67-79. doi:10.1016/j.jep.2014.06.006

Li, X.-L., Gao, L.-H., Li, H.-M., Wang, L.-T., Lee, K.-H., and Li, R.-T. (2015b). Diterpenoids from the Stems of Tripterygium Hypoglaucum (Celastraceae) and Cytotoxic Evaluation. Phytochem. Lett. 12. doi:10.1016/j.phytol.2015.02.018
Li, X. G., and He, L. (2006). Pharmacological Control Study between Tripterygium Hypoglaucum Hutch and Tripterygium Wilfordii Hook F. J. Kunming Med. Coll. 12, 527723. doi:10.3969/j.issn.1005-9202.2011.18.040

Li, Y. B., Nie, J., Lü, C., Hu, X. L., and Xue Gy, L. C. (2011). Influence of Triptolide on the Expression of Interleukin-1 $\beta$ and Prostaglandin E2 in Rat Microglia Induced by Beta-Amyloid Protein. Chin. J. Gerontol. 31, 3521-3523.

Li, Z., Wu, X., Li, J., Yao, L., Sun, L., Shi, Y., et al. (2012b). Antitumour Activity of Celastrol Nanoparticles in a Xenograft Retinoblastoma Tumour Model. Int. J. Nanomedicine 7, 2389-2398. doi:10.2147/IJN.S29945

Li, Z., Yan, M., Cao, L., Fang, P., Guo, Z., Hou, Z., et al. (2017b). Glycyrrhetinic Acid Accelerates the Clearance of Triptolide through P-Gp In Vitro. Phytother. Res. 31, 1090-1096. doi:10.1002/ptr.5831

Li, Z. Y., Wu, Q., Yan, Z., Li, D., Pan, X., Qiu, T., et al. (2013b). Prevention of Acute GVHD in Mice by Treatment with Tripterygium Hypoglaucum Hutch Combined with Cyclosporin A. Hematology 18, 352-359. doi:10.1179/ 1607845413Y.0000000076

Liang, Z.-Q., Cao, N., Song, Z.-K., and Wang, X. (2006). In Vitro porcine Brain Tubulin Assembly Inhibition by Water Extract from a Chinese Medicinal Herb, Tripterygium Hypoglaucum Hutch. World J. Gastroenterol. 12, 1133-1135. doi:10.3748/wjg.v12.i7.1133

Lin, H.-F., Hsieh, M.-J., Hsi, Y.-T., Lo, Y.-S., Chuang, Y.-C., Chen, M.-K., et al. (2017). Celastrol-induced Apoptosis in Human Nasopharyngeal Carcinoma Is Associated with the Activation of the Death Receptor and the Mitochondrial Pathway. Oncol. Lett. 14, 1683-1690. doi:10.3892/ol.2017.6346

Lin, N., Liu, C., Xiao, C., Jia, H., Imada, K., Wu, H., et al. (2007). Triptolide, a Diterpenoid Triepoxide, Suppresses Inflammation and Cartilage Destruction in Collagen-Induced Arthritis Mice. Biochem. Pharmacol. 73, 136-146. doi:10.1016/j.bcp.2006.08.027

Lin, N., Sato, T., and Ito, A. (2001). Triptolide, a Novel Diterpenoid Triepoxide from Tripterygium Wilfordii Hook. f., Suppresses the Production and Gene Expression of Pro-matrix Metalloproteinases 1 and 3 and Augments Those of Tissue Inhibitors of Metalloproteinases 1 and 2 in Human Synovia. Arthritis Rheum. 44, 2193-2200. doi:10.1002/1529-0131(200109)44:9<2193::aidart373>3.0.co;2-5

Liu, H.-K., Perrier, S., Lipina, C., Finlay, D., McLauchlan, H., Hastie, C. J., et al. (2006). Functional Characterisation of the Regulation of CAAT Enhancer Binding Protein Alpha by GSK-3 Phosphorylation of Threonines 222/226. BMC Mol. Biol. 7, 14. doi:10.1186/1471-2199-7-14

Liu, J., Lee, J., Salazar Hernandez, M. A., Mazitschek, R., and Ozcan, U. (2015). Treatment of Obesity with Celastrol. Cell 161, 999-1011. doi:10.1016/ j.cell.2015.05.011

Liu, J., Wu, Q.-L., Feng, Y.-H., Wang, Y.-F., Li, X.-Y., and Zuo, J.-P. (2005). Triptolide Suppresses CD80 and CD86 Expressions and IL-12 Production in THP-1 Cells. Acta Pharmacol. Sin. 26, 223-227. doi:10.1111/j.17457254.2005.00035.x

Liu, L., Luo, Y., Zhou, M., Lu, Y., Xing, M., Ru, Y., et al. (2019). Tripterygium Agents for the Treatment of Atopic Eczema: A Bayesian Analysis of Randomized Controlled Trials. Phytomedicine 59, 152914. doi:10.1016/ j.phymed.2019.152914

Liu, L., Salnikov, A. V., Bauer, N., Aleksandrowicz, E., Labsch, S., Nwaeburu, C., et al. (2014a). Triptolide Reverses Hypoxia-Induced EpithelialMesenchymal Transition and Stem-like Features in Pancreatic Cancer by NF-Kb Downregulation. Int. J. Cancer 134, 2489-2503. doi:10.1002/ ijc. 28583

Liu, Q., Chen, T., Chen, H., Zhang, M., Li, N., Lu, Z., et al. (2004). Triptolide (PG490) Induces Apoptosis of Dendritic Cells through Sequential P38 MAP Kinase Phosphorylation and Caspase 3 Activation. Biochem. Biophys. Res. Commun. 319, 980-986. doi:10.1016/j.bbrc.2004.04.201

Liu, Q. (2011). Triptolide and its Expanding Multiple Pharmacological Functions. Int. Immunopharmacol. 11, 377-383. doi:10.1016/j.intimp.2011.01.012

Liu, Y., Chen, Y., Liu, F. Q., Lamb, J. R., and Tam, P. K. H. (2008). Combined Treatment with Triptolide and Rapamycin Prolongs Graft Survival in a Mouse Model of Cardiac Transplantation. Transpl. Int. Off. J. Eur. Soc. Organ. Transpl. 21, 483-494. doi:10.1111/j.1432-2277.2007.00630.x

Liu, Y., Song, F., Wu, W. K. K., He, M., Zhao, L., Sun, X., et al. (2012). Triptolide Inhibits colon Cancer Cell Proliferation and Induces Cleavage and Translocation of 14-3-3 Epsilon. Cell Biochem. Funct. 30, 271-278. doi:10.1002/cbf.2793 
Liu, Z.-Z., Zhao, R.-H., Liu, Y.-T., Zhang, H.-W., Ding, G., Ma, Z., et al. (2014b). A New Dihydroagarofuranoid Sesquiterpene from the Roots of Tripterygium Hypoglaucum. J. Asian Nat. Prod. Res. 16, 327-331. doi:10.1080/ 10286020.2013.873410

Liu, Z., Zhao, R., and Zou, Z. (2011). Chemical Constituents from Root Bark of Tripterygium Hypoglaucum. Zhongguo Zhong Yao Za Zhi 36, 2503-2506.

Lü, S., Wang, Q., Li, G., Sun, S., Guo, Y., and Kuang, H. (2015). The Treatment of Rheumatoid Arthritis Using Chinese Medicinal Plants: From Pharmacology to Potential Molecular Mechanisms. J. Ethnopharmacol. 176, 177-206. doi:10.1016/j.jep.2015.10.010

Lu, Y., Fukuda, K., Nakamura, Y., Kimura, K., Kumagai, N., and Nishida, T. (2005). Inhibitory Effect of Triptolide on Chemokine Expression Induced by Proinflammatory Cytokines in Human Corneal Fibroblasts. Invest. Ophthalmol. Vis. Sci. 46, 2346-2352. doi:10.1167/iovs.05-0010

Lu, Y., Zhang, Y., Li, L., Feng, X., Ding, S., Zheng, W., et al. (2014). TAB1: a Target of Triptolide in Macrophages. Chem. Biol. 21, 246-256. doi:10.1016/ j.chembiol.2013.12.009

Lue, Y., Sinha Hikim, A. P., Wang, C., Leung, A., Baravarian, S., Reutrakul, V., et al. (1998). Triptolide: a Potential Male Contraceptive. J. Androl. 19, 479-486.

Luo, D., Zuo, Z., Zhao, H., Tan, Y., and Xiao, C. (2019). Immunoregulatory Effects of Tripterygium Wilfordii Hook F and its Extracts in Clinical Practice. Front. Med. 13, 556-563. doi:10.1007/s11684-018-0649-5

Lv, H., Jiang, L., Zhu, M., Li, Y., Luo, M., Jiang, P., et al. (2019). The Genus Tripterygium: A Phytochemistry and Pharmacological Review. Fitoterapia 137, 104190. doi:10.1016/j.fitote.2019.104190

Ma, B., Qi, H., Li, J., Xu, H., Chi, B., Zhu, J., et al. (2015). Triptolide Disrupts Fatty Acids and Peroxisome Proliferator-Activated Receptor (PPAR) Levels in Male Mice Testes Followed by Testicular Injury: A GC-MS Based Metabolomics Study. Toxicology 336, 84-95. doi:10.1016/j.tox.2015.07.008

Ma, J., Schmidt, B. M., Poulev, A., and Raskin, I. (2008). Determination of Tripdiolide in Root Extracts of Tripterygium Wilfordii by Solid-phase Extraction and Reversed-phase High-Performance Liquid Chromatography. Phytochem. Anal. 19, 348-352. doi:10.1002/pca.1059

Mathews, V., Chendamarai, E., George, B., Viswabandya, A., and Srivastava, A. (2011). Treatment of Acute Promyelocytic Leukemia with Single-Agent Arsenic Trioxide. Mediterr. J. Hematol. Infect. Dis. 3, e2011056. doi:10.4084/ MJHID.2011.056

Matsui, Y., Watanabe, J., Ikegawa, M., Kamoto, T., Ogawa, O., and Nishiyama, H. (2008). Cancer-specific Enhancement of Cisplatin-Induced Cytotoxicity with Triptolide through an Interaction of Inactivated Glycogen Synthase Kinase3beta with P53. Oncogene 27, 4603-4614. doi:10.1038/onc.2008.89

McDonald, D. M. (2001). Angiogenesis and Remodeling of Airway Vasculature in Chronic Inflammation. Am. J. Respir. Crit. Care Med. 164, S39-S45. doi:10.1164/ajrccm.164.supplement_2.2106065

Mishra, P., and Ambs, S. (2015). Metabolic Signatures of Human Breast Cancer. Mol. Cel. Oncol. 2, e992217. doi:10.4161/23723556.2014.992217

Miyata, Y., Sato, T., and Ito, A. (2005). Triptolide, a Diterpenoid Triepoxide, Induces Antitumour Proliferation via Activation of C-Jun NH2-terminal Kinase 1 by Decreasing Phosphatidylinositol 3-kinase Activity in Human Tumour Cells. Biochem. Biophys. Res. Commun. 336, 1081-1086. doi:10.1016/j.bbrc.2005.08.247

Mou, H., Zheng, Y., Zhao, P., Bao, H., Fang, W., and Xu, N. (2011). Celastrol Induces Apoptosis in Non-small-cell Lung Cancer A549 Cells through Activation of Mitochondria- and Fas/FasL-Mediated Pathways. Toxicol. Vitro 25, 1027-1032. doi:10.1016/j.tiv.2011.03.023

Nie, J., Zhou, M., Lü, C., Hu, X., Wan, B., Yang, B., et al. (2012). Effects of Triptolide on the Synaptophysin Expression of Hippocampal Neurons in the AD Cellular Model. Int. Immunopharmacol. 13, 175-180. doi:10.1016/j.intimp.2012.03.021

Ning, C., Mo, L., Chen, X., Tu, W., Wu, J., Hou, S., et al. (2018). Triptolide Derivatives as Potential Multifunctional Anti-alzheimer Agents: Synthesis and Structure-Activity Relationship Studies. Bioorg. Med. Chem. Lett. 28, 689-693. doi:10.1016/j.bmcl.2018.01.019

Nong, C., Wang, X.-Z., Jiang, Z.-Z., and Zhang, L.-Y. (2019). [Progress of Effect and Mechanisms of Tripterygium Wilfordii on Immune System]. Zhongguo Zhong Yao Za Zhi = Zhongguo Zhongyao Zazhi = China J. Chin. Mater. Med. 44, 3374-3383. doi:10.19540/j.cnki.cjcmm.20190419.401

Oda, K., and Kitano, H. (2006). A Comprehensive Map of the Toll-like Receptor Signalling Network. Mol. Syst. Biol. 2, 0015. doi:10.1038/msb4100057
Onyeabor, F., Paik, A., Kovvasu, S., Ding, B., Lin, J., Wahid, M. A., et al. (2019). Optimization of Preparation and Preclinical Pharmacokinetics of CelastrolEncapsulated Silk Fibroin Nanoparticles in the Rat. Molecules 24, 3271. doi:10.3390/molecules24183271

Pan, X.-D., Chen, X.-C., Zhu, Y.-G., Chen, L.-M., Zhang, J., Huang, T.-W., et al. (2009). Tripchlorolide Protects Neuronal Cells from Microglia-Mediated BetaAmyloid Neurotoxicity through Inhibiting NF-kappaB and JNK Signalling. Glia 57, 1227-1238. doi:10.1002/glia.20844

Petronelli, A., Pannitteri, G., and Testa, U. (2009). Triterpenoids as New Promising Anticancer Drugs. Anticancer. Drugs 20, 880-892. doi:10.1097/ CAD.0b013e328330fd90

Qian, S. Z., Hu, Y. Z., Wang, S. M., Luo, Y., Tang, A. S., Shu, S. Y., et al. (1988). Effects of Tripterygium Hypoglaucum (Lévl.) Hutch on Male Fertility. Adv. Contracept. Off. J. Soc. Adv. Contracept. 4, 307-310. doi:10.1007/BF01849272

Ren, Z., Zhang, C., Wang, L., Cui, Y., Qi, R., Yang, C., et al. (2010). In Vitro antiviral Activity of the Total Alkaloids from Tripterygium Hypoglaucum against Herpes Simplex Virus Type 1. Virol. Sin. 25, 107-114. doi:10.1007/s12250-0103092-6

Rodríguez-Martínez, S., Cancino-Diaz, M. E., Miguel, P.-S., and CancinoDiaz, J. C. (2006). Lipopolysaccharide from Escherichia coli Induces the Expression of Vascular Endothelial Growth Factor via Toll-like Receptor 4 in Human Limbal Fibroblasts. Exp. Eye Res. 83, 1373-1377. doi:10.1016/ j.exer.2006.07.015

Seo, W. Y., Goh, A. R., Ju, S. M., Song, H. Y., Kwon, D.-J., Jun, J.-G., et al. (2011). Celastrol Induces Expression of Heme Oxygenase-1 through ROS/Nrf2/ARE Signalling in the HaCaT Cells. Biochem. Biophys. Res. Commun. 407, 535-540. doi:10.1016/j.bbrc.2011.03.053

Seo, W. Y., Ju, S. M., Song, H. Y., Goh, A. R., Jun, J.-G., Kang, Y.-H., et al. (2010). Celastrol Suppresses IFN-Gamma-Induced ICAM-1 Expression and Subsequent Monocyte Adhesiveness via the Induction of Heme Oxygenase1 in the HaCaT Cells. Biochem. Biophys. Res. Commun. 398, 140-145. doi:10.1016/j.bbrc.2010.06.053

Shamon, L. A., Pezzuto, J. M., Graves, J. M., Mehta, R. R., Wangcharoentrakul, S. Sangsuwan, R., et al. (1997). Evaluation of the Mutagenic, Cytotoxic, and Antitumour Potential of Triptolide, a Highly Oxygenated Diterpene Isolated from Tripterygium Wilfordii. Cancer Lett. 112, 113-117. doi:10.1016/S03043835(96)04554-5

Shan, W.-G., Wang, H.-G., Chen, Y., Wu, R., Wen, Y.-T., Zhang, L.-W., et al. (2017). Synthesis of 3- and 29-substituted Celastrol Derivatives and StructureActivity Relationship Studies of Their Cytotoxic Activities. Bioorg. Med. Chem. Lett. 27, 3450-3453. doi:10.1016/j.bmcl.2017.05.083

Shao, F., Wang, G., Xie, H., Zhu, X., Sun, J., and Jiye, A. (2007). Pharmacokinetic Study of Triptolide, a Constituent of Immunosuppressive Chinese Herb Medicine, in Rats. Biol. Pharm. Bull. 30, 702-707. doi:10.1248/bpb.30.702

Song, Q., Xiang, Y., Gu, J., Chen, J., and Li, X. (2021). Chemical Constituents from the Rhizomes of Tripterygium Hypoglaucum. J. Chinese Med. Mater., 355-358. doi:10.13863/j.issn1001-4454.2021.02.018

Song, W., Liu, M., Wu, J., Zhai, H., Chen, Y., and Peng, Z. (2019). Preclinical Pharmacokinetics of Triptolide: A Potential Antitumour. Drug. Curr. Drug Metab. 20, 147-154. doi:10.2174/1389200219666180816141506

Sun, L., Li, H., Huang, X., Wang, T., Zhang, S., Yang, J., et al. (2013). Triptolide Alters Barrier Function in Renal Proximal Tubular Cells in Rats. Toxicol. Lett. 223, 96-102. doi:10.1016/j.toxlet.2013.08.014

Tabeshpour, J., Mehri, S., Shaebani Behbahani, F., and Hosseinzadeh, H. (2018). Protective Effects of Vitis vinifera (Grapes) and One of its Biologically Active Constituents, Resveratrol, against Natural and Chemical Toxicities: A Comprehensive Review. Phytother. Res. 32, 2164-2190. doi:10.1002/ptr.6168

Tai, T., Huang, X., Su, Y., Ji, J., Su, Y., Jiang, Z., et al. (2014). Glycyrrhizin Accelerates the Metabolism of Triptolide through Induction of CYP3A in Rats. J. Ethnopharmacol. 152, 358-363. doi:10.1016/j.jep.2014.01.026

Tang, Y., Zhang, Y., Li, L., Xie, Z., Wen, C., and Huang, L. (2020). Kunxian Capsule for Rheumatoid Arthritis: Inhibition of Inflammatory Network and Reducing Adverse Reactions through Drug Matching. Front. Pharmacol. 11, 485. doi:10.3389/fphar.2020.00485

Tao, J., Hu, Q., Yang, J., Li, R., Li, X., Lu, C., et al. (2007). In Vitro anti-HIV and -HSV Activity and Safety of Sodium Rutin Sulfate as a Microbicide Candidate. Antivir. Res 75, 227-233. doi:10.1016/j.antiviral.2007.03.008 
Tao, X., Schulze-Koops, H., Ma, L., Cai, J., Mao, Y., and Lipsky, P. E. (1998). Effects of Tripterygium Wilfordii Hook F Extracts on Induction of Cyclooxygenase 2 Activity and Prostaglandin E2 Production. Arthritis Rheum. 41, 130-138. doi:10.1002/1529-0131(199801)41:1<130::AID-ART16>3.0.CO;2-4

Tozawa, K., Sagawa, M., and Kizaki, M. (2011). Quinone Methide Tripterine, Celastrol, Induces Apoptosis in Human Myeloma Cells via NF-Kb Pathway. Int. J. Oncol. 39, 1117-1122. doi:10.3892/ijo.2011.1161

Tseng, C.-K., Hsu, S.-P., Lin, C.-K., Wu, Y.-H., Lee, J.-C., and Young, K.-C. (2017). Celastrol Inhibits Hepatitis C Virus Replication by Upregulating Heme Oxygenase-1 via the JNK MAPK/Nrf2 Pathway in Human Hepatoma Cells. Antivir. Res 146, 191-200. doi:10.1016/j.antiviral.2017.09.010

Hu, Y. H., Zeng, K. Q., Zhang, M. M., Tu, S. H., Lai, X. Y., Zhang, W. C., et al. (2004). Effects of Triptolide on the Expression and Activity of Nuclear Factor $\kappa B$ in Synovium of Collagen-Induced Arthritis Rats. Chin. J. Rheumatol. 25 (5), 543-545. doi:10.1007/BF02896012

Vlietinck, A. J., and Vanden Berghe, D. A. (1991). Can Ethnopharmacology Contribute to the Development of Antiviral Drugs? J. Ethnopharmacol. 32, 141-153. doi:10.1016/0378-8741(91)90112-q

Wang, C., Shi, C., Yang, X., Yang, M., Sun, H., and Wang, C. (2014). Celastrol Suppresses Obesity Process via Increasing Antioxidant Capacity and Improving Lipid Metabolism. Eur. J. Pharmacol. 744, 52-58. doi:10.1016/ j.ejphar.2014.09.043

Wang, F., Zhang, Y., and Zhao, Y. Q., (2011). Study on Chemical Constituents of Tripterygium Hypoglaucum. Chin. Herb. Med. 42, 46-49.

Wang, J.-M., Li, J.-Y., Cai, H., Chen, R.-X., Zhang, Y.-Y., Zhang, L.-L., et al. (2019). Nrf2 Participates in Mechanisms for Reducing the Toxicity and Enhancing the Antitumour Effect of Radix Tripterygium Wilfordii to S180-Bearing Mice by Herbal-Processing Technology. Pharm. Biol. 57, 437-448. doi:10.1080/ 13880209.2019.1634106

Wang, L., Xu, D., Li, L., Xing, X., Liu, L., Ismail Abdelmotalab, M., et al. (2018a). Possible Role of Hepatic Macrophage Recruitment and Activation in Triptolide-Induced Hepatotoxicity. Toxicol. Lett. 299, 32-39. doi:10.1016/ j.toxlet.2018.08.017

Wang, S., Wang, L., and Chen, X., (2020). Diterpenoids of the Stem and Leaf of Tripterygium Hypoglaucum and Their Biological Activities. J. Kunming Univ. Sci. Technol. Sci. Ed. 45, 108-114. doi:10.16112/j.cnki.53-1223/n.2020.02.014

Wang, S., Zuo, S., Liu, Z., Ji, X., Yao, Z., and Wang, X. (2018b). Study on the Efficacy and Mechanism of Triptolide on Treating TNF Transgenic Mice with Rheumatoid Arthritis. Biomed. Pharmacother. 106, 813-820. doi:10.1016/ j.biopha.2018.07.021

Wang, W.-B., Feng, L.-X., Yue, Q.-X., Wu, W.-Y., Guan, S.-H., Jiang, B.-H., et al. (2012). Paraptosis Accompanied by Autophagy and Apoptosis Was Induced by Celastrol, a Natural Compound with Influence on Proteasome, ER Stress and Hsp90. J. Cel. Physiol. 227, 2196-2206. doi:10.1002/jcp.22956

Wang, Y.-L., Lam, K.-K., Cheng, P.-Y., and Lee, Y.-M. (2015). Celastrol Prevents Circulatory Failure via Induction of Heme Oxygenase-1 and Heat Shock Protein 70 in Endotoxemic Rats. J. Ethnopharmacol. 162, 168-175. doi:10.1016/j.jep.2014.12.062

Wang, Y., Guo, S.-H., Shang, X.-J., Yu, L.-S., Zhu, J.-W., Zhao, A., et al. (2018c). Triptolide Induces Sertoli Cell Apoptosis in Mice via ROS/JNK-dependent Activation of the Mitochondrial Pathway and Inhibition of Nrf2-Mediated Antioxidant Response. Acta Pharmacol. Sin. 39, 311-327. doi:10.1038/ aps.2017.95

Wang, Z., Ma, D., Wang, C., Zhu, Z., Yang, Y., Zeng, F., et al. (2017). Triptonide Inhibits the Pathological Functions of Gastric Cancer-Associated Fibroblasts. Biomed. Pharmacother. 96, 757-767. doi:10.1016/j.biopha.2017.10.046

Wei, Y. M., Luan, Z. H., Liu, B. W., Wang, Y. H., Chang, Y. X., Xue, H. Q., et al. (2019). Autophagy in Triptolide-Mediated Cytotoxicity in Hepatic Cells. Int. J. Toxicol. 38, 436-444. doi:10.1177/1091581819864518

Li, W. W., Li, B. G., and Chen, Y. Z. (1999). Sesquiterpene Alkaloids from Tripterygium Hypoglaucum. Phytochemistry 40. doi:10.1016/S0031-9422(98) 00618-9

Wishart, D. S., Mandal, R., Stanislaus, A., and Ramirez-Gaona, M. (2016). Cancer Metabolomics and the Human Metabolome Database. Metabolites 6, 10. doi:10.3390/metabo6010010

Wong, K.-F., Chan, J. K., Chan, K.-L., Tam, P., Yang, D., Fan, S.-T., et al. (2008). Immunochemical Characterization of the Functional Constituents of
Tripterygium Wilfordii Contributing to its Anti-inflammatory Property. Clin. Exp. Pharmacol. Physiol. 35, 55-59. doi:10.1111/j.1440-1681.2007.04740.x Wu, D. G., Sun, X. C., and Li, F. (1979). New Diterpene Lactones of Tripterygium Wilfordii - Hypoglaucine and Triptolide CKunming Acta Bot. Yunnanica. 29-36.

Xi, C., Peng, S., Wu, Z., Zhou, Q., and Zhou, J. (2017). Toxicity of Triptolide and the Molecular Mechanisms Involved. Biomed. Pharmacother. 90, 531-541. doi:10.1016/j.etap.2017.09.013

Xie, C. Q., Zhou, P., and Li, X. (2015). Research Progress on Chemical Constituents, Pharmacological Effects, and Clinical Application of Tripterygium Hypoglaucum. Chin. Tradit. Herbal Drugs. 46. 1996-2010. doi:10.7501/j.issn.0253-2670.2015.13.024

Xie, F. G., Li, C. J., Yang, J. Z., Luo, Y. M., and Zhang, D. M. (2012). Study on Chemical Constituents from the Root Bark of Tripterygium Hypoglaucum. J. Chin. Med. Mater. 35, 1083-1087. doi:10.13863/j.issn1001-4454.2012.07.023

Xie, L., Zhao, Y., Duan, J., Fan, S., Shu, L., Liu, H., et al. (2020). Integrated Proteomics and Metabolomics Reveal the Mechanism of Nephrotoxicity Induced by Triptolide. Chem. Res. Toxicol. 33, 1897-1906. doi:10.1021/ acs.chemrestox.0c00091

Xu, H.-Y., Zhang, Y.-Q., Liu, Z.-M., Chen, T., Lv, C.-Y., Tang, S.-H., et al. (2019). ETCM: an Encyclopaedia of Traditional Chinese Medicine. Nucleic Acids Res. 47, D976-D982. doi:10.1093/nar/gky987

Xu, W., Ziqing, L., Yinrun, D., Xiaoyan, W., and Jinglun, X. (2004). Tripterygium Hypoglaucum (Level) Hutch Induces Aneuploidy of Chromosome 8 in Mouse Bone Marrow Cells and Sperm. Mutagenesis 19, 379-382. doi:10.1093/mutage/ geh044

Xue, S., and Wu, T. (2008). Chinese Herbal Medicine Tripterygium Hypoglaucum Hutch Tablet for Facial Corticosteroid Addiction Dermatitis. J. Altern. Complement. Med. 14, 619. doi:10.1089/acm.2008.0142

Yan, G., Zhang, H., Wang, W., Li, Y., Mao, C., Fang, M., et al. (2017). Investigation of the Influence of Glycyrrhizin on the Pharmacokinetics of Celastrol in Rats Using LC-MS and its Potential Mechanism. Xenobiotica 47, 607-613. doi:10.1080/00498254.2016.1211773

Yan, Q., Li, Y., Fan, Y., Zhang, M., Yang, L., Yao, Y., et al. (2019). Protective Effect of Syringaresinol on Excitatory Damage Induced by Sodium Glutamate in SHSy5y Cells. Chin. J. Exp. Tradit. Med. Formulae 25, 76-82. doi:10.13422/ j.cnki.syfjx.20191839

Yang, G., Wang, L., Yu, X., Huang, Y., Qu, C., Zhang, Z., et al. (2017). Protective Effect of $18 \beta$-Glycyrrhetinic Acid against Triptolide-Induced Hepatotoxicity in Rats. Evid. Based. Complement. Alternat. Med. 2017, 3470320. doi:10.1155/ $2017 / 3470320$

Yang, L., Li, Y., Ren, J., Zhu, C., Fu, J., Lin, D., et al. (2014). Celastrol Attenuates Inflammatory and Neuropathic Pain Mediated by Cannabinoid Receptor Type 2. Int. J. Mol. Sci. 15, 13637-13648. doi:10.3390/ijms 150813637

Yang, T., Wang, S., Zheng, H., Wang, L., Liu, D., Chen, X., et al. (2019). Understanding Dihydro- $\beta$-Agarofuran Sesquiterpenes from Tripterygium Hypoglaucum as the Modulators of Multi-Drug Resistance in HepG2/Adr Cells. Biochem. Biophys. Res. Commun. 508, 742-748. doi:10.1016/ j.bbrc.2018.11.188

Yi, J. H., Yang, H., Zhang, Q. L., Pei, T. R., Chen, Z. Z., and Hu, Y. B., (1993). Studies on Chemical Constituents of Tripterygium Hypoglaucum. Chin. Tradit. Herb. Drugs 24, 398-400+446.

Yu, H., Shi, L., Zhao, S., Sun, Y., Gao, Y., Sun, Y., et al. (2016). Triptolide Attenuates Myocardial Ischemia/Reperfusion Injuries in Rats by Inducing the Activation of Nrf2/HO-1 Defense Pathway. Cardiovasc. Toxicol. 16, 325-335. doi:10.1007/ s12012-015-9342-y

Yu, L., Wang, L., and Chen, S. (2010). Endogenous Toll-like Receptor Ligands and Their Biological Significance. J. Cel. Mol. Med. 14, 2592-2603. doi:10.1111/ j.1582-4934.2010.01127.x

Yu, Y., Koehn, C. D., Yue, Y., Li, S., Thiele, G. M., Hearth-Holmes, M. P., et al. (2015). Celastrol Inhibits Inflammatory Stimuli-Induced Neutrophil Extracellular Trap Formation. Curr. Mol. Med. 15, 401-410. doi:10.2174/ 1566524015666150505160743

Yuan, S., Wang, L., Chen, X., Fan, B., Yuan, Q., Zhang, H., et al. (20202016). Corrigendum to "Triptolide Inhibits the Migration and Invasion of Human Prostate Cancer Cells via Caveolin-1/CD147/MMPs Pathway". Biomed. Pharmacother. 84, 1776-1782. doi:10.1016/j.biopha.2019.109782 
Yuan, Z., Hasnat, M., Liang, P., Yuan, Z., Zhang, H., Sun, L., et al. (2019a). The Role of Inflammasome Activation in Triptolide-Induced Acute Liver Toxicity. Int. Immunopharmacol. 75, 105754. doi:10.1016/j.intimp.2019.105754

Yuan, Z., Zhang, H., Hasnat, M., Ding, J., Chen, X., Liang, P., et al. (2019b). A New Perspective of Triptolide-Associated Hepatotoxicity: Liver Hypersensitivity upon LPS Stimulation. Toxicology 414, 45-56. doi:10.1016/j.tox.2019.01.005

Zhang, J., Liu, S.-J., Hu, J.-H., Xu, M.-J., Liu, Z.-X., Zhou, L., et al. (2016). [LC-MS/MS Method for Determination of Tripterine in Plasma Pharmacokinetic Study in Beagles]. Zhongguo Zhong Yao Za Zhi= Zhongguo Zhongyao Zazhi = China J. Chin. Mater. Med. 41, 2727-2731. doi:10.4268/cjcmm20161426

Zhang, J., Shan, J., Chen, X., Li, S., Long, D., and Li, Y. (2018). Celastrol Mediates Th17 and Treg Cell Generation via Metabolic Signalling. Biochem. Biophys. Res. Commun. 497, 883-889. doi:10.1016/j.bbrc.2018.02.163

Zhang, L., and Zhang, Z. X., (1992). Studies on Chemical Constituents of Tripterygium Hypoglaucum. Chinese Tradit. Herb. Drugs. 23, $339-340+360+390$.

Zhang, L., Zhang, Z. X., and An, D. K., (1998). Study on Ether Soluble Chemical Constituents of Tripterygium Hypoglaucum. Chinese Tradit. Herb. Drugs 35, 441-442. doi:10.3321/j.issn:0253-2670.2007.04.004

Zhang, R., Chen, Z., Wu, S.-S., Xu, J., Kong, L.-C., and Wei, P. (2019a). Celastrol Enhances the Anti-liver Cancer Activity of Sorafenib. Med. Sci. Monit. Int. Med. J. Exp. Clin. Res. 25, 4068-4075. doi:10.12659/MSM.914060

Zhang, X. M., Wang, C. F., and Wu, D. G. (1992a). Aconitine Triterpenes from the Roots of Tripterygium Hypoglaucum. Kunming Acta Bot. Yunnanica., 211-214.

Zhang, X. M., Wang, C. F., and Wu, D. G. (1992b). Rosin Alkane Diterpenoids from the Roots of Tripterygium Hypoglaucum. Kunming Acta Bot. Yunnanica. 319-322.

Zhang, X., Xue, X.-C., Wang, Y., Cao, F.-F., You, J., Uzan, G., et al. (2019b). Celastrol Reverses Palmitic Acid-Induced Insulin Resistance in HepG2 Cells via Restoring the miR-223 and GLUT4 Pathway. Can. J. Diabetes 43, 165-172. doi:10.1016/j.jcjd.2018.07.002

Zhang, Y., Mao, X., Li, W., Chen, W., Wang, X., Ma, Z., et al. (2021a). Tripterygium Wilfordii: An Inspiring Resource for Rheumatoid Arthritis Treatment. Med. Res. Rev. 41, 1337-1374. doi:10.1002/med.21762

Zhang, Y., Tang, Y., Luo, Y., Luo, L., Shen, F., and Huang, Z. (2021b). Triptolide Impairs Glycolysis by Suppressing GATA4/Sp1/PFKP Signalling axis in Mouse Sertoli Cells. Toxicol. Appl. Pharmacol. 425, 115606. doi:10.1016/j.taap.2021.115606

Zhang, Y. W., Fan, Y. S., Wang, X. D., Gao, W. Y., and Duan, H. Q. (2007). Diterpenoids with Immunosuppressive Activity from Tripterygium Hypoglaucum. Chinese Tradit. Herb. Drugs 38, 493-496. doi:10.3321/j.issn: 0253-2670.2007.04.004

Zhao, P., Wang, H., Jin, D.-Q., Ohizumi, Y., Xu, J., and Guo, Y. (2014). Terpenoids from Tripterygium Hypoglaucum and Their Inhibition of LPS-Induced NO Production. Biosci. Biotechnol. Biochem. 78, 370-373. doi:10.1080/ 09168451.2014.890035

Zhao, Q., Li, H.-M., Chen, X.-Q., Li, R.-T., and Liu, D. (2018). Terpenoids from Tripterygium Hypoglaucum and Their Anti-inflammatory Activity. Chem. Nat. Compd. 54. doi:10.1007/s10600-018-2381-4
Zhen, Q. S., Ye, X., and Wei, Z. J. (1995). Recent Progress in Research on Tripterygium: a Male Antifertility Plant. Contraception 51, 121-129. doi:10.1016/0010-7824(94)00018-r

Zheng, H., Wang, L., Yang, T., Liu, D., Li, H.-M., Chen, X.-Q., et al. (2020). New Terpenoids and Lignans from the Twigs of Tripterygium Hypoglaucum. Nat. Prod. Res. 34, 1853-1861. doi:10.1080/14786419.2018.1564297

Zhong, J., Xian, D., Xu, Y., and Liu, J. (2011). Efficacy of Tripterygium Hypoglaucum Hutch in Adults with Chronic Urticaria. J. Altern. Complement. Med. 17, 459-464. doi:10.1089/acm.2009.0648

Zhou, H., Liu, Y., Wang, C., Liu, L., Wang, H., Zhang, Y., et al. (2018). Triptolide Inhibits Epstein-Barr Nuclear Antigen 1 Expression by Increasing Sensitivity of Mitochondria Apoptosis of Nasopharyngeal Carcinoma Cells. J. Exp. Clin. Cancer Res. 37, 192. doi:10.1186/s13046-018-0865-5

Zhou, J., Xi, C., Wang, W., Fu, X., Jinqiang, L., Qiu, Y., et al. (2014). Triptolideinduced Oxidative Stress Involved with Nrf2 Contribute to Cardiomyocyte Apoptosis through Mitochondrial Dependent Pathways. Toxicol. Lett. 230, 454-466. doi:10.1016/j.toxlet.2014.08.017

Zhou, X., Liu, Q., Zhou, X., Zhang, J., Liu, W., Zhao, X., et al. (2020). THH Relieves CIA Inflammation by Reducing Inflammatory-Related Cytokines. Cell Biochem. Biophys. 78, 367-374. doi:10.1007/s12013-020-00911-8

Zhu, H., Liu, X.-W., Ding, W.-J., Xu, D.-Q., Zhao, Y.-C., Lu, W., et al. (2010). Upregulation of Death Receptor 4 and 5 by Celastrol Enhances the Anti-cancer Activity of TRAIL/Apo-2L. Cancer Lett. 297, 155-164. doi:10.1016/ j.canlet.2010.04.030

Zhu, K.-J., Shen, Q.-Y., Cheng, H., Mao, X.-H., Lao, L.-M., and Hao, G.-L. (2005). Triptolide Affects the Differentiation, Maturation and Function of Human Dendritic Cells. Int. Immunopharmacol. 5, 1415-1426. doi:10.1016/ j.intimp.2005.03.020

Zhuang, W. J., Fong, C. C., Cao, J., Ao, L., Leung, C. H., Cheung, H. Y., et al. (2004). Involvement of NF-kappaB and C-Myc Signalling Pathways in the Apoptosis of HL-60 Cells Induced by Alkaloids of Tripterygium Hypoglaucum (levl.) Hutch. Phytomedicine 11, 295-302. doi:10.1078/0944711041495128

Conflict of Interest: The authors declare that the research was conducted in the absence of any commercial or financial relationships that could be construed as a potential conflict of interest.

Publisher's Note: All claims expressed in this article are solely those of the authors and do not necessarily represent those of their affiliated organizations, or those of the publisher, the editors and the reviewers. Any product that may be evaluated in this article, or claim that may be made by its manufacturer, is not guaranteed or endorsed by the publisher.

Copyright (c) 2021 Zhao, Zhang, Xiao, Wu, Hu, Jiang, Zhang, Wei, Ma and Zhang. This is an open-access article distributed under the terms of the Creative Commons Attribution License (CC BY). The use, distribution or reproduction in other forums is permitted, provided the original author(s) and the copyright owner(s) are credited and that the original publication in this journal is cited, in accordance with accepted academic practice. No use, distribution or reproduction is permitted which does not comply with these terms. 


\section{GLOSSARY}

17 $\beta$-HSD $17 \beta$-hydroxysteroid dehydrogenase

2-HIB 2-hydroxyisobutyrate

2-HIV 2-hydroxyisovalerate

3 $\beta$-HSD $3 \beta$-hydroxysteroid dehydrogenase

ABCA1 ATP-binding cassette transporter A1

AD Alzheimer's disease

aGVHD acute graft versus host disease

ALP alkaline phosphatase

ALT alanine aminotransfease

AML acute myeloid leukaemia

AMPKa Adenosine 5'-monophosphate (AMP)-activated protein kinase

APCs antigen presenting cells

APL acute promyelocytic leukemia

ARC hypothalamic arcuate nucleus

$\mathrm{As}_{2} \mathrm{O}_{3}$ arsenic trioxide

AST aspartate aminotransferase

ATL adult T-cell leukaemia/lymphoma

AUC Area Under Curve

Bcl-xL B-cell lymphoma-2

CD Crohn's disease

c-Fos Cellular oncogene fos

CIA collagen II-induced arthritis

c-Jun Cellular Jun

c-Myc cancer-Myc

COX cyclo-oxygen-ase

CPT1A Carnitine Palmitoyl transferase 1A

CRC colorectal carcinoma

Ctr calcitonin receptor

Ctsk cathepsin $\mathrm{K}$

CXCL2 C-X-C motif ligand 2

DCs dendritic cells

Drp1 dynamin-related protein 1

EBV Epstein-Barr virus

ERK extracellular regulated protein kinases

Foxp3 Forkhead box P3

GA glycyrrhetinic acid

GCAFs gastric cancer-associated fibroblasts

GLUT1 glucose transporter 1

GLUT4 glucose transporter 4

GPx glutathione peroxidase;

GSH glutathione

HCV hepatitis $\mathrm{C}$ virus
HIF-1 $\alpha$ hypoxia-inducible factor 1- $\alpha$

HK2 hexokinase 2

HLA-DR human leukocyte antigen DR

HO-1 haem oxygenase-1

HSF1 heatshocktranscription factor 1

HSP70 Heat shock $70 \mathrm{kDa}$ protein

HUVEC human umbilical vein endothelial cells

IFN-g interferon gamma

IKK ІкB kinase

IL1R1 interleukin 1 receptor 1

IL-1 $\beta$ interleukin-1 $\beta$

IL-6 interleukin-6

iNOS inducible Nitric Oxide Synthase (enzyme)

JNK1 c-Jun N-terminal kinase 1

LDH Lactic Dehydrogenase

LDL/VLDL low-density lipoprotein/very low-density lipoprotein LPS lipopolysaccharide

MAPK mitogen-activated protein kinase

MCP monocyte chemotactic protein

MDA malondialdehyde

MDM2 murine double minute2

MDR multidrug resistance

MIP macrophage inflammatory protein

miR-96 microRNA-96

MLRs mixed lymphocyte reactions

Mmp-9 matrix metalloprotein 9

MMPs matrix metalloproteinases

MoDCs monocyte-derived DCs

mTOR mammalian target of Rapamycin

NAC N-acetylcysteine

NADPH nicotinamide adenine dinucleotide phosphate

NFATc nuclear factor activated T-cells

NF-kB nuclear factor kappa-B

NO nitric oxide

OPG osteoprotegerin

P450c17 cytochrome P450 17-hydroxylase

P450scc P450 side-chain cleavage enzyme

PARP poly ADP-ribose polymerase

PBMCs peripheral blood mononuclear cells

PC Pancreatic cancer

PFKP Phosphofructokinase Platelet

PGE2 prostaglandin E2

P-gp P-glycoprotein

PI3K phosphatidylinositol 3-kinase 
PKC protein kinase $\mathrm{C}$

PKC $\boldsymbol{\theta}$ Protein Kinase C $\theta$

PLC phospholipase C

proMMP-1 pro-matrix metalloproteinase-1

PTP protein tyrosine phosphatase

RA rheumatoid arthritis

RANKL receptor activator of NF- $\kappa B$ ligand

RNS reactive nitrogen species

ROS reactive oxygen species

SOD superoxide dismutase

StAR steroidogenic acute regulatory protein

STAT signal transducers and activators of transcription

TAB1 TAK1 binding protein
TAK1 transforming growth factor $\beta$-activated kinase 1

TAs Tripterygium agents

TCM Traditional Chinese medicine

TCPTP T cell PTP

THH Tripterygium hypoglaucum (Lévl.) Hutch.

TLR Toll-like receptors

TNF- $\boldsymbol{\alpha}$ tumour necrosis factor- $\boldsymbol{\alpha}$

TRAIL TNF-related apoptosis-inducing ligand

TRAP tartrate-resistant acid phosphatase

Tregs $\mathrm{T}$ regulatory cells

TwHF Tripterygium wilfordii Hook F.

VEGF vascular endothelial growth factor

XIAP X-linked inhibitor of apoptosis protein 